\title{
The blind catfish from the caves of Chapada Diamantina, Bahia, Brazil (Siluriformes: Heptapteridae): description, anatomy, phylogenetic relationships, natural history, and biogeography
}

\author{
Flávio A. Bockmann and Ricardo M. C. Castro
}

\begin{abstract}
Rhamdiopsis krugi, a new troglobitic heptapterid catfish, is described from the caves of Chapada Diamantina, State of Bahia, northeastern Brazil. This species, although frequently cited in the scientific literature along the last seventeen years, remained undescribed largely due to its uncertain phylogenetic affinities. The generic assignment of $R$. krugi was clouded largely by its high number of unusual morphological features (some related to cave life), for instance: absence of eyes and body pigmentation; presence of a widely exposed pseudotympanum; posterior border of the anterior branch and anterior margin of the arborescent portion of the posterior branch of the transverse process of fourth vertebra joined; dorsal hypural plate commonly with seven rays; ventral caudal plate usually with six rays; dorsal and ventral caudal-fin lobes typically with six branched fin rays each; 38 39 vertebrae; anal fin with 14-17 rays; and lateral line very short. Rhamdiopsis krugi can be easily distinguished from its congeners, $R$. microcephala and $R$. moreirai, by its troglomorphic features and by the presence of a shorter lateral line, fewer vertebrae and anal-fin rays, pattern of branching of caudal-fin rays, and several attributes of skeletal system. The affinities of this new species are discussed in light of current phylogenetic knowledge of the family Heptapteridae. Incongruent derived characters do not allow selection of a particular hypothesis of sister group relationships among species of Rhamdiopsis. The occurrence of $R$. krugi in the rio Paraguaçu basin is possibly due to an event of hydrological capture from a section of the middle portion of the rio São Francisco basin, caused by tectonic events. The semi-arid region where $R$. krugi presently lives was probably covered by a wide forested area during a humid cycle in Quaternary. A summary of natural history and ecology data of $R$. krugi, as well as notes on its conservation, are provided. We also offer comments on the morphological plasticity of $R$. krugi.
\end{abstract}

Rhamdiopsis krugi, um novo bagre heptapterídeo troglóbio, é descrito de cavernas da Chapada Diamantina, Estado da Bahia, nordeste do Brasil. Esta espécie, embora frequentemente citada na literatura ao longo dos últimos dezessete anos, não foi descrita antes em função das suas afinidades filogenéticas incertas. A posição genérica de $R$. krugi foi obscurecida principalmente pelo seu alto número de caracteres morfológicos incomuns (parte deles relacionada à vida nas cavernas), como por exemplo: ausência de olhos e de pigmentação corporal; presença de um pseudotímpano amplamente exposto; borda posterior do ramo anterior e margem anterior da porção arborescente do ramo posterior do processo transverso da quarta vértebra conectados um ao outro; placa hipural dorsal normalmente com sete raios; placa caudal ventral usualmente com seis raios; lobos dorsal e ventral da nadadeira caudal tipicamente com seis raios ramificados cada; 38-39 vértebras; nadadeira anal com 14-17 raios; e linha lateral muito curta. Rhamdiopsis krugi pode ser facilmente distinguida de seus congêneres, $R$. microcephala e $R$. moreirai, por seus caracteres troglomórficos e pela presença de uma linha lateral mais curta, menos vértebras e raios na nadadeira anal, padrão de ramificação dos raios da nadadeira caudal e vários atributos do sistema esquelético. As afinidades desta nova espécie são discutidas à luz do conhecimento atual sobre a filogenia da família Heptapteridae. Caracteres derivados incongruentes não permitem optar por uma hipótese particular de relação de grupo-irmão entre as espécies de Rhamdiopsis. A ocorrência de R. krugi na bacia do rio Paraguaçu é devida, possivelmente, a um evento de captura hidrológica de uma seção da porção média da bacia do rio São Francisco, ocasionada por eventos tectônicos. A região semi-árida onde $R$. krugi atualmente vive estava provavelmente coberta por uma ampla floresta durante um ciclo úmido no Quaternário. Um sumário das informações sobre a história natural e ecologia de $R$. krugi, assim como observações sobre sua conservação, são apresentadas. Apresentamos também comentários sobre a plasticidade morfológica de $R$. krugi.

Key words: Conservation, Morphology, Neotropics, Troglomorphism.

Laboratório de Ictiologia de Ribeirão Preto, Departamento de Biologia, Programa de Pós-Graduação em Biologia Comparada, Universidade de São Paulo. Av. dos Bandeirantes 3900, 14040-901 Ribeirão Preto, São Paulo, Brazil. fabockmann@ffclrp.usp.br, rmcastro@ffclrp.usp.br 


\section{Introduction}

Most species of fishes restricted to subterranean habitats are siluriforms, with about 50 species in the Americas, mainly concentrated in the Neotropical region (Trajano, 2003; Bichuette \& Trajano, 2005, 2008; Fernandez et al., 2007; Shibatta et al., 2007). The prevalence of siluriforms in the troglobitic habitats, including caves, is likely explained by their morphological/ biological "preadaptations", viz. their predominantly nocturnal activity (and related chemo-orientation), cryptobiotic habits, and generalized carnivorous (or detritivorous) diet (Trajano, 2003; Trajano et al., 2004). Among subterranean catfishes, 13 putatively valid species belong to the Neotropical family Heptapteridae: Phreatobius cisternarum Göldi, P. dracunculus Shibatta, MurielCunha \& de Pinna, P. sanguijuela Fernandez, Saucedo, CarvajalVallejos \& Schaefer, Pimelodella kronei (Miranda-Ribeiro), $P$. spelaea Trajano, Reis \& Bichuette, Rhamdia enfurnada Bichuette \& Trajano, R. guasarensis DoNascimiento, Provenzano \& Lundberg, R. laluchensis Weber, Allegrucci \& Sbordoni, R. macuspanensis Weber \& Wilkens, R. reddelli Miller, R. typhla Greenfield, Greenfield \& Woods, R. urichi (Norman), and $R$. zongolicensis Wilkens. Although Silfvergrip (1996), in his revision of Rhamdia Bleeker, sunk all troglobitic species of the genus known to that date into $R$. laticauda (Kner) and $R$. quelen (Quoy \& Gaimard), these taxonomic moves did not find acceptance among researchers working on cave-dwelling fishes (e.g., Weber \& Wilkens, 1998; Wilkens, 2001; Weber et al., 2003). Such diversity is only paralleled by the Neotropical catfish family Trichomycteridae, with 14 cave-dwelling described species (Bichuette et al., 2008; Castellanos-Morales, 2008).

Some troglobitic fishes have very distinctive morphological and behavioral characters, several of them associated with their life styles in the darkness (e.g., eyes little to not developed, pigmentation scanty or absent, laterosensory canal system not fully developed), which, depending on their degree of development, may obscure its precise phylogenetic relationships. This is the case of the genus Phreatobius Göldi, which has been assigned to distinct siluriform families (Bockmann \& Guazzelli, 2003). A second example and the objective of this publication is the troglobitic catfish from the Chapada Diamantina region (mostly known from the Poço Encantado cave), which has remained undescribed until now despite the extensive scientific literature on its ecology and behavior published through the last 17 years (see references in the synonymy), including an unpublished Master Dissertation (Mendes, 1995a). Although its position within the Heptapteridae is currently undisputable, there are many uncertainties concerning its affinities within this family. These doubts are expressed in its unstable generic allocation, having been included in Imparfinis Eigenmann \& Norris (e.g., Trajano \& Menna-Barreto, 1995; Trajano, 1996, 1997a), Rhamdella Eigenmann \& Eigenmann (e.g., Trajano, 1993; Trajano \& Sánchez, 1994), Rhamdiopsis Haseman (Trajano, 2007), and even dealt as an undescribed genus (e.g., Trajano, 1997b, 1998, 2001a, 2001b, 2003; Trajano \& Bockmann, 1999a; Trajano \& Bichuette, 2006; Volpato \& Trajano, 2006). However, the increasing knowledge of the relationships among heptapterids has produced a more rigorous environment for investigating the affinities of this taxon (e.g., Bockmann, 1998; Bockmann \& Ferraris, 2005; Bockmann \& Miquelarena, 2008). Thus, the present study aims to describe the blind and unpigmented heptapterid from the caves of Chapada Diamantina, State of Bahia, northeastern Brazil, provide a complete synonymy, summarize its ecological and behavioral data, and investigate its phylogenetic and biogeographic relationships.

\section{Material and Methods}

Measurements and counts were made on left side whenever possible. All measurements were made point-to-point. Morphometric values were taken with digital calipers and expressed to the nearest $0.1 \mathrm{~mm}$. Methodology and terminology for measurements followed Bockmann \& de Pinna (2004), excluding those inapplicable due to absence of eyes and nasal barbels. The following measurements were added: body width, taken at maximum width at the level of dorsal-fin origin, and length of dorsal- and ventral- caudal fin lobes, which considered the longest rays of each caudal lobe, usually corresponding to the dorsalmost branched ray of the dorsal lobe and the ventralmost branched ray of the ventral lobe. Subunits of head were presented as proportions of head length (HL), except for measurements of barbels, which were converted to proportions of standard length (SL). Head length and measurements of body parts were given as proportions of SL.

Methodology and terminology for taking meristic data and fin positions followed Bockmann \& de Pinna (2004). The first vertebra with a complete hemal spine was also reported. Gill rakers were counted on first branchial arch. All anal-fin rays were counted individually, including the anterior splints and the two most posterior rays that insert on the same base. When a ray is distally-broken or ill-formed, this element is counted and its branching pattern is presumed, whenever possible, according to adjacent rays. Vertebral counts included all vertebrae (including the first five modified into a complex vertebrae), and the compound caudal centrum (PU1+U1) (Lundberg \& Baskin, 1969) was treated as a single element. Numbers of pterygiophores, pleural ribs, rays associated to caudal skeleton, and vertebrae, and number of vertebra bearing first complete hemal spine and fin positions, were taken from cleared and stained preparations and radiographs. Numbers of procurrent rays and branchiostegal rays were verified with aid of transmitted illumination. For the record of fin origins and ends, the landmarks are always the total vertebrae (i.e., the first five vertebrae associated to the weberian complex are counted). The angle formed between the spine of the vertebra in the middle of caudal peduncle (normally the $5^{\text {th }}$ free vertebra counted back to front) and the vertebral column took into account the main body of spine, excluding its usually curved tip. Dorsal caudal and dorsal hypural plates were distinguished from each other, with the former including the uroneural and the hypurals 3, 4, and 5 and the latter comprising the hypurals 3, 4, and 5 only. Cleared and counterstained specimens were prepared according to Taylor \& van Dyke (1985). 
Terminology for skeleton and cephalic laterosensory canals follow Bockmann \& Miquelarena (2008) and Northcutt (1989), respectively. Pelvic girdle is named according to Shleden (1937). Nomenclature and homologies for supraorbital and infraorbital sensory canal systems follow Arratia \& Huaquín (1995); and for preoperculomandibular sensory canal system follow Bockmann \& Miquelarena (2008). Muscles and cranial neves (and their subdivisions) are named according to Winterbottom (1974) and Herrick (1899, 1901), respectively. Anatomical illustrations were sketched using a stereomicroscope with a camera lucida attachment. In the drawings, bone is represented by stipple and cartilage by open circles.

In the synonymy, the notation "in partim" is used to denote that part of information only refers to the new species. All data concerning to blind catfishes from localities other than those of the type series were excluded from synonymy, but commentaries on these are done elsewhere in this article. Taking into account that a substantial volume of original information on the new species is found in abstracts of scientific meetings only, these were exceptionally included in its synonymy.

Abbreviations for institutions are: Carnegie Museum, Pittsburgh (CM); Field Museum of Natural History, Chicago (FMNH); Laboratório de Ictiologia de Ribeirão Preto, Universidade de São Paulo, Ribeirão Preto (LIRP); Museu de Ciências e Tecnologia da Pontifícia Universidade Católica do Rio Grande do Sul, Porto Alegre (MCP); Museu de História Natural Capão da Imbuia, Curitiba (MHNCI); Museu de Zoologia da Universidade de São Paulo, São Paulo (MZUSP); Universidade Federal do Rio de Janeiro, Rio de Janeiro (UFRJ); Zoologisk Museum, Københavns Universitet, Copenhagen (ZMUC).

Additional specimens of the genus Rhamdiopsis are listed in the Comparative material section; remaining heptapterid specimens examined are listed in Bockmann \& Miquelarena (2008) and are not repeated here.

\section{Rhamdiopsis krugi, new species Figs. 1-13}

Anophthalmic and unpigmented heptapterid catfishes... from Chapada Diamantina, northeastern Brazil [in partim]. Bichuette, 2004: 73 [Poço Encantado, Natal, and Bode caves]. Bagre... do Poço Encantado. -Mendes, 1997a: 70.

Bagre do Poço Encantado. -Mendes, 1997a: 70-71.

Bagres [from Poço Encantado, Itaetê, Chapada Diamantina, State of Bahia]. -Mendes, 1997a: 70; Mendes, 1998a: 26.

Bagres cegos. -Karmann et al., 2002: 497.

Bagres da família Heptapteridae [from Chapada Diamantina]. -Trajano \& Bichuette, 2005a: 103.

Bagres de uma nova espécie de gênero ainda não descrito da família Heptapteridae [from Chapada Diamantina]. -Trajano \& Bichuette, 2006: 84.

Bagres despigmentados... da Chapada Diamantina. -Trajano, 1998: 89
Bagrinho cego da Chapada Diamantina. -Trajano, 1998: 89-90]. Bagrinhos da Chapada Diamantina [in partim]. -Trajano \& Bichuette, 2006: 51, 54.

Blind catfish from Chapada Diamantina. -Trajano \& Bockmann, 2000: 213.

Blind heptapterine from Chapada Diamantina. -Trajano \& Bockmann, 2000: 213.

Blind pimelodid from Bahia. -Trajano, 1995: 206.

Brazilian blind heptapterine from Chapada Diamantina. -Trajano \& Bockmann, 2000: 213.

Brazilian heptapterines [in partim]. -Trajano, 2001a: 152.

Brazilian [troglobitic] siluriforms [in partim]. -Trajano, 2001a: 153.

Cave catfishes from Chapada Diamantina. -Trajano et al., 2005: 233.

Cave fishes [from Chapada Diamantina, northeastern Brazil] [in partim]. -Trajano et al., 2005: 233-235, fig. 1.

Cave heptapterines of the subclade Nemuroglanis [in partim]. -Trajano \& Bockmann, 1998: 86.

Espécie de bagre cego (Subfamília Heptapterinae). -Karmann et al., 2002: 491.

Espécie de Pimelodídeos ainda não descrita. -Mendes, 1995b: L1-L2 [Poço Encantado, Lapa do Bode, and Gruta Natal caves, Chapada Diamantina, Bahia].

Espécie troglóbia de Imparfinis. -Trajano, 1996: 19.

Gênero novo ainda não descrito formalmente. -Trajano \& Bichuette, 2006: 75 .

Gênero novo da Chapada Diamantina. -Trajano \& Bichuette, 2006: 38 [photograph of live specimen].

Heptapteridae unnamed species. -Bichuette \& Trajano, 2005: 594 [Brazil, State of Bahia, Municipality of Itaetê, Lapa do Bode, rio Paraguaçu basin].

[troglobitic] Heptapterids from Bahia [in partim]. -Trajano et al., 2004:322.

Heptapterine from Chapada Diamantina. -Trajano \& Bockmann, 2000: 214.

Highly modified Brazilian troglobitic catfish, from caves in Chapada Diamantina [in partim]. -Trajano et al., 2005: 230.

Imparfinis [sp.]- Mendes, 1995b: L1; Trajano \& MennaBarreto, 1995: 345 [Gruta Natal cave], 349, 351; Trajano, 1996: 19; Trajano, 1997a: 59 [Lapa do Bode cave]; Trajano, 1997c: 365; Trajano \& de Pinna, 1996: 88; Mendes et al., 1997: 196 [Poço Encantado, Lapa do Bode, and Gruta Natal]; Trajano \& Bockmann, 1997: 72; Trajano, 1998: 89; Trajano \& Menna-Barreto, 2000: 470.

Imparfinis catfishes. -Mendes, 1995c: 100; Trajano, 1997c: 358 [Poço Encantado].

Imparfinis catfishes [in partim]. -Trajano \& Menna-Barreto, 1995: 345.

Imparfinis [sp.], from NE Brazil. -Trajano \& Menna-Barreto, 1995: 343.

Imparfinis sp- Mendes, 1995c: 100 [Poço Encantado]; Trajano \& Gerhard, 1997: 127.

Imparfinis sp. -Mendes, 1995c: 99-100; Trajano \& MennaBarreto, 1995: 345, table 1, 348, figs. 4-5, 350-351; Trajano, 1996: 19, fig. 7; Trajano \& Menna-Barreto, 1996: 330, 334; Trajano \& de Pinna, 1996: 88-89; Trajano, 1997a: 54, 58-59 [Poço Encantado cave], 61; Trajano, 1997c: 364-365 [Poço 
Encantado]; Trajano, 1997d: 176; Trajano, 1997e: 176 [lake in cave in Itaetê, State of Bahia]; Trajano \& Bockmann, 1999a: 124; Trajano \& Bockmann, 2000: 208; Trajano, 2001a: 134; Trajano, 2003: 606; Trajano et al., 2005: 230.

New cave genus [Heptapterinae]. -Trajano \& Bockmann, 1998: 86. New genus [Heptapterinae]. -Trajano \& Bockmann, 1998: 86; Trajano \& Bockmann, 1999b: 70; Trajano, 2001a: 141, table 2.

New genus [from Chapada Diamantina] [in partim]. -Trajano \& Bichuette, 2005b: 162.

New genus of Chapada Diamantina. -Trajano \& Bockmann, 1999a: 127.

New genus form [sic] Chapada Diamantina. -Trajano \& Bockmann, 1999a: 126.

New genus from Chapada Diamantina. -Trajano \& Bockmann, 1999a: 124, 126-127; Trajano \& Bockmann, 2000: 214; Trajano \& Menna-Barreto, 2000: 470.

New genus from Chapada Diamantina, Central Bahia State. -Trajano \& Bockmann, 2000: 208.

New genus from Chapada Diamantina, northeastern Brazil [in partim]. -Trajano \& Bichuette, 2005b: 161.

New genus from Chapada Diamantina, State of Bahia, northeastern Brazil. -Bockmann \& Guazzelli, 2003: 409.

New [heptapterine] genus from NE Brazil. -Trajano \& Bockmann, 1999b: 70; Trajano, 2001a: 144.

New genus, new sp. -Trajano \& Bockmann, 1999a: unnumb. page, fig. 1, 125, fig. 3 .

New genus, new sp. [in partim]- Trajano, 1997b: 122 [Chapada Diamantina region, rio Paraguaçu basin, Central Bahia: Poço Encantado and Lapa do Bode caves, at right side of the rio Una, Municipality of Itaetê, and Natal cave, at the left side of the rio Una].

New heptapterid catfish from Chapada Diamantina (NE Brazil). -Trajano \& Bichuette, 2007: 114.

New heptapterid genus [in partim]. -Bichuette \& Trajano, 2005: 588; Trajano \& Bichuette, 2005b: 162-163.

New heptapterid genus from Chapada Diamantina. -Bichuette \& Trajano, 2005: 592.

New heptapterids from Bahia [in partim]. -Trajano et al., 2004: 323.

New Heptapterinae. -Trajano, 2003: 610, table 20.3 [Poço Encantado cave].

New heptapterine form [sic] Chapada Diamantina. -Volpato \& Trajano, 2006: 142-143.

New heptapterine from Chapada Diamantina. -Trajano \& Bockmann, 2000: 208, 214; Volpato \& Trajano, 2006: 142.

New heptapterine from NE Brazil. -Trajano, 2001a: 148; Trajano, 2003: 610.

New heptapterine genus. -Trajano, 2001a: 138, 139, table 1, 140-142, 145, 150, 157; Trajano, 2001b: 195; Trajano, 2003: 607, table 20.2, 608-609.

New heptapterine genus from central Bahia, northeast Brazil. -Trajano, 2003: 610 .

New heptapterine genus from Chapada Diamantina. -Trajano \& Menna-Barreto, 2000: 477.

New heptapterine genus from NE Brazil. -Trajano, 2001a: 135136, 140, 153; Trajano, 2003: 619.
New heptapterine genus from northeastern Brazil. -Trajano et al., 2002: 182; Trajano, 2003: 608.

New heptapterine taxon from NE Brazil. -Trajano, 2001a: 150.

New pimelodid from Chapada Diamantina. -Trajano \& Gerhard, 1997: 134

New, undescribed genus. -Trajano, 2003: 604, table 20.1.

New, undescribed genus and species of Heptapteridae [in partim]. -Trajano et al., 2005: 230 [Poço Encantado cave, Chapada Diamantina, Central State of Bahia], 231, 233, 235.

New, undescribed genus, from Brazil. -Bichuette \& Trajano, 2005: 588 .

New, undescribed heptapterine genus and species. -Trajano, 2003: 606 .

Nouvelle espèce de poisson-chat Pimelodité troglobie du nord-est. -Trajano \& Sánchez, 1994: pl. 1, fig. B [Poço Encantado].

Nova espécie da Chapada Diamantina. -Trajano \& Bichuette, 2006: 79.

Nova espécie de bagre (pimelodídeo) cego e despigmentado. -Castro \& Trajano, 1993: 67 [two limestone caves in Municipality of Itaetê, Chapada Diamantina region, State of Bahia].

Nova espécie de Pimelodidae cego de Cavernas (Itaetê, BA). -Souza et al., 1994: 18.

Nova espécie troglóbia de Imparfinis. -Mendes, 1997b: 395 [Poço Encantado, Chapada Diamantina, State of Bahia].

Novo gênero da Chapada Diamantina. -Trajano \& Bichuette, 2006: 76.

Novo gênero da Chapada Diamantina (BA). -Trajano \& Bichuette, 2006: 75.

Pimelodid catfish from Chapada Diamantina, Imparfinis sp. -Trajano \& Gerhard, 1997: 133.

População de pequenos bagres cegos. -Mendes, 1995d: 15, 17.

$R$ [hamdella]. sp. -Swarça et al., 2000: 591, table 2 [Itaetê, State of Bahia].

Rhamdella [sp.]- Trajano, 1993: 259; Castro \& Trajano, 1993: 67; Souza et al., 1994: 18 [Itaetê, Chapada Diamantina, State of Bahia].

Rhamdella sp. -Trajano, 1993: 259; Trajano \& Sánchez, 1994: 535, table 2 [speleological province of Bambuí, State of Bahia (Chapada Diamantina)]; Trajano \& Bockmann, 1999a: 124; Trajano \& Bockmann, 2000: 208.

Rhamdiopsis [sp.] [in partim]- Trajano, 2007: 192 [Chapada Diamantina, northeastern Brazil], 193-194.

Rhamdiopsis catfish [in partim]- Bichuette et al., 2008 [Chapada Diamantina: 306].

Rhamdiopsis sp. [in partim]- Trajano, 2007: 195-196.

Small pimelodid catfish belonging to the genus Imparfinis. Mendes, 1995c: 99 [poço Encatando (sic) cave, Gruta Natal, and Lapa do Bode, Chapada Diamantina, State of Bahia].

The most modified among the Brazilian troglobitic fishes (a pimelodid catfish) [from caves of State of Bahia]. -Trajano, 1995: 206.

Troglobitic heptapterid from Chapada Diamantina, NE Brazil [from Poço Encantado]. -Trajano et al., 2005: 232, table 1.

Troglobitic heptapterines [in partim]. -Trajano, 2001a: 149. 
Two undescribed species of heptapterine catfishes (Pimelodidae) [in partim]. -Trajano \& Bockmann, 1997: 72 [Chapada Diamantina, northeastern Brazil], 73.

Undescribed and very specialized species of Rhamdella from northeastern Brazil. -Trajano, 1993: 259.

Undescribed genus and species of Brazilian heptapterine from NE Brazil. -Trajano, 2001a: 134.

Undescribed Heptapterinae from Chapada Diamantina, Bahia, northeastern Brazil. -Trajano \& Gerhard, 1997: 127.

Undescribed, highly troglomorphic [heptapterid] species from the State of Bahia, northeastern Brazil [in partim]. -Trajano et al., 2004: 321.

Undescribed species of a new genus from Chapada Diamantina, NE Brazil. -Volpato \& Trajano, 2006: 141.

Undescribed species of Rhamdella (probably). -Mendes, 1994: 44 [Poco (sic) Encantado, Chapada Diamantina, State of Bahia].

Undescribed taxon, probably a new genus and species, from NE Brazil. -Trajano, 2001b: 195.

Holotype. LIRP 5929, $37.1 \mathrm{~mm}$ SL, Brazil, State of Bahia, Municipality of Itaetê, Poço Encantado cave, on the left margin of the rio Una (a right side affluent of rio Paraguaçu) $12^{\circ} 56^{\prime} 41.8^{\prime \prime} \mathrm{S}$ 4106'17.3"W, ca. 340 m a.s.1., 11 Jan 1991, R. M. C. Castro, L. Krug, L. F. Mendes \& H. F. Santos.

Paratypes. LIRP 5930, 10, 20.4-35.5 mm SL, 2 c\&s (27.8-35.0 mm SL), MZUSP 92609, 2, 29.4-31.0 mm SL, collected with the holotype; LIRP 5928, 10, 20.8-33.9 mm SL, 2 c\&s (25.9-33.9 mm SL), Brazil, State of Bahia, Municipality of Itaetê, Lapa do Bode cave, adjacent to the left margin of the rio Una (a right side affluent of rio Paraguaçu) $12^{\circ} 56^{\prime} 06.5^{\prime}$ 'S $41^{\circ} 03$ '53.9' 'W, ca. $340 \mathrm{~m}$ a.s.1., 2 Nov 1991, R. M. C. Castro, P. Gnaspini Neto, L. F. Mendes, P. Schwartz \& E. Trajano; LIRP 5931, $34.9 \mathrm{~mm} \mathrm{SL}$, Brazil, State of Bahia, Municipality of Itaetê, Gruta Natal cave, on the right margin of the rio Una (a right side affluent of rio Paraguaçu) 12 $2^{\circ} 59^{\prime} 32.4$ "S $41^{\circ} 05^{\prime} 32.8^{\prime \prime} \mathrm{W}$, ca. $340 \mathrm{~m}$ a.s.1., 23 Jan 1994, E. Trajano.

Diagnosis. Rhamdiopsis krugi differs from its two congeners, $R$. microcephala (Lütken) and $R$. moreirai Haseman, by the following characteristics: 1) ethmoid cartilage discontinuous (vs. continuous) (Fig. 4); 2) eyes absent and optic foramen atrophied ( $v s$. eyes present and non-atrophied optic foramen) (Figs. 1-2, 4b); 3) longer barbels, as expressed by the length of maxillary barbel with $32.2-43.3 \% \mathrm{SL}$ (vs. $21.2-29.3 \% \mathrm{SL}$ in $R$. microcephala, and 18.9-28.6\% SL in R. moreirai) (Figs. 1-3, 12-13); 4) supraorbital and infraorbital sensory canals not connected to each other anteriorly (vs. united) (Figs. 3b, 4a); $5)$ presence of $\mathrm{s} 7$ branch and pore of the supraorbital laterosensory canal (vs. s7 branch and pore absent) (Fig. 4a); 6) subpreopercle absent (vs. present) (Fig. 5); 7) anterior and posterior branches of the transverse process 4 co-ossified to each other ( $v s$. anterior and posterior branches of transverse process 4 not joined to each other) (Fig. 7, see arrow); 8) posterior limb of transverse process 4 undivided, with spatulated shape ( $v s$. with a deep medial notch which divides it into two divergent, approximately symmetrical, long arms) (Fig. 7); 9) posterolateral corner of posterior portion of the posterior branch of the transverse process of vertebra 4 extending approximately to midlength of the transverse process of vertebra 5 ( $v s$. extending to the lateral tip of transverse process of vertebra 5) (Fig. 7);10) presence of a widely exposed pseudotympanum ( $v s$. pseudotympanum barely visible externally) (Fig. 2); 11) dorsal fin larger, as expressed by dorsal-fin base with 11.2-14.1\% SL and length of third dorsal-fin ray with $14.4-18.7 \%$ SL ( $v s$. dorsal-fin base with 8.9-11.4\% SL and length of third dorsal-fin ray with 13.8$16.4 \%$ SL in $R$. microcephala; and dorsal-fin base with 6.5 9.6\% SL and length of third dorsal-fin ray with $12.3-14.3 \% \mathrm{SL}$ in $R$. moreirai) (Figs. 1-2, 12-13); 12) posterior lobe of the adipose fin straight ( $v s$. rounded) (Figs. 1, 12-13); 13) anal fin deep and rounded (vs. low and rectangular) (Figs. 1, 12-13); 14) shorter anal-fin base, supported typically by $14-15$, less commonly 13 or 16-17 rays (vs. 20-21 rays in $R$. microcephala and 23-25 rays in $R$. moreirai) (Figs. 1, 12-13); 15) hypural 5 usually co-ossified to hypural 4 at its distal portion ( $v s$. hypural 5 autogenous) (Fig. 11a); 16) dorsal hypural plate typically with 7 , rarely 6 or 8 rays (vs. 8) (Fig. 11); 17) dorsal caudal-fin lobe typically with 6 , rarely 4,5 or 7 branched rays (vs. 7 , rarely 6 , in $R$. microcephala, and 7 in $R$. moreirai); 18) ventral caudal plate typically with 6 , rarely 7 rays (vs. 8-9 in $R$. microcephala and 7 in R. moreirai) (Fig. 11); 19) ventral caudal-fin lobe typically with 6 , rarely 4 or 5 branched rays (vs. 7-8 in R. microcephala and 8-9 in R. moreirai); 20) body relatively shorter, with 38-40 vertebrae (vs. 42-44 vertebrae in $R$. microcephala and 43-44 vertebrae in $R$. moreirai), and probably related origin of pelvic-fin below the centra of vertebrae 12-14 (vs. 14-15) and origin of adipose fin usually above the centra of vertebrae 22-24 (vs. 24-26); 21) lateral line very short, with $5-15$ pores, usually reaching from the vertical through posterior region of pseudotympanum to the vertical through dorsal-fin origin ( $v s$. lateral line long, reaching to the level of posterior half of adipose fin) (Fig. 3a); 22) fatty tissue broadly spread through the body ( $v s$. fatty tissue not widely distributed, restricted to some areas of body); 23) adults of small body size, reaching $38.5 \mathrm{~mm}$ SL ( $v s$. larger size, reaching $78 \mathrm{~mm} \mathrm{SL}$ in $R$. microcephala and $117 \mathrm{~mm} \mathrm{SL}$ in $R$. moreirai) (Table 1$) ; 24$ ) body unpigmented (vs. pigmented) (Figs. 1-2, 12-13); 25) non-cryptobiotic behavior, expressed by marked midwater activity ( $v s$. cryptobiotic behavior, usually hiding inside the marginal vegetation); 26) non-photophobic behavior ( $v s$. photophobic behavior); 27) poorly-developed circadian rhythms (vs. marked circadian rhythms); and 28) life in lentic habitat ( $v s$. life in lotic habitat). Characters 1-2, 4-10, 12-13, 15-19, and 21-28 are autapomorphies; characters 11 and 14 are plesiomorphies; and characters 3 and 20 are of uncertain polarity. It may be further separated from $R$. microcephala by two attributes: 1) epiphyseal branches of supraorbital laterosensory canals not fused to each other, each one bearing its own pore, the s6 pore ( $v s$. epiphyseal branches of supraorbital laterosensory canals fused to each other, ending in a single symphyseal pore, the s6+s6 complex pore); and 2) basal third of the posterior border of the adipose fin connected with the dorsal fold of caudal fin, leaving a 
large, almost complete free posterior lobe ( $v s$. adipose fin mostly confluent with dorsal fold of caudal fin for about $2 / 3$ of its posterior border, leaving a small posterior free lobe).

Description. Table 1 presents morphometrics of holotype and paratypes. See Fig. 1 for general body shape. Body relatively elongate, its cross-section roughly circular predorsally, gradually becoming more compressed caudally. Lateral profile of trunk above pectoral fins strongly convex (produced by wide swimbladder), slightly convex from this point to pelvic-fin origin, and approximately straight from this point to end of trunk. Caudal peduncle relatively narrow and very compressed, gradually merging with caudal fin in dorsal view. Anterior dorsal profile of body gently convex, with a discrete hump between posterior limit of head and dorsal-fin origin. Dorsal profile of head gently convex, almost straight, continuous with dorsal profile of trunk. Dorsal profile of trunk posterior to dorsal-fin base straight to base of caudal fin. Ventral profile of head slightly convex. Abdominal region outlined by a distinct convexity. Ventral trunk contour slightly concave or rectilinear from pelvic-fin origin to anal-fin origin, almost straight along anal-fin base, and straight to base of caudal fin. Posterior body depth gradually decreasing caudally. Large triangular hiatus in hypaxial musculature lateral to anterior portion of swimbladder, almost extending to posterior limit of pectoral fin, forming pseudotympanum. Pseudotympanum framed by anteriormost myomeres of obliquus superioris muscle, dorsally, and of obliquus inferioris muscle, ventrally, which are attached to first pleural rib. Axillary pore absent. Urogenital and anal openings adjacent to each other; anal opening approximately on vertical through middle of pelvic fin. Fatty tissue, represented by small, rounded corpuscles, broadly distributed along body, more visible through base of fins, and opercular, branchiostegal, pectoral, and abdominal regions.

Head longer than broad, depressed, and elliptical to trapezoidal in dorsal view (Figs. 1-3). Dorsum of head covered by thin, almost transparent skin. Eyes completely absent, without any vestige of eyeballs in all specimens. Deep longitudinal facial ridge marking dorsal limits of adductor mandibulae muscle, extending from base of maxillary barbel to or just anterior of level of fourth infraorbital laterosensory pore (i4). Anterior and posterior nares far apart from each other, with separation slightly lesser than distance between anterior and posterior nares. Anterior nare surrounded by tubular flap of integument. Posterior nare wide, elliptical, with transverse axis the longest. Posterior nostril surrounded by low flap anteriorly and laterally; posterior border devoid of flap. Mouth subterminal; gape gently convex anteriorly, slightly downturned at corners. Skin of lips with fleshy rictal fold at corner of gape. Rictal fold ventrally subtended by submandibular groove that extends anteriorly to site approximately adjacent to third peoperculomandibular pore (pm3). Upper and lower lips each subdivided by sulcus into two transverse folds. Premaxilla and dentary with 4-6 rows of small viliform teeth. Anteriormost tooth row of each premaxilla with 18-26 teeth; anteriormost tooth row of each dentary with 24-35 teeth (larger specimens with more teeth). Palate and vomer edentulous. Gular fold distinct, fleshy, and broadly V-shaped with rounded apex. Posteroventral portion of opercle and branchiostegal region delimited by a distinct ridge on lateral surface of head extending from distal tip of opercle to a point between eighth and ninth pores of preoperculomandibular laterosensory canal (pm8 and pm9), ventrally.

Branchiostegal membranes well-developed, free, anteriorly overlapping, united to isthmus only at medial apex, and not connected to each other anteriorly (Fig. 3). Branchiostegal rays 7 (20), rarely $6\left(4^{*}\right)$. Branchial rakers short, curved, 3 (1), $4(1), 5(7), 6(12 *), 7(2), 8(1)$ on first ceratobranchial (including one on angle formed with epibranchial), and $0(3)$ or $1\left(21^{*}\right)$ on first epibranchial.

Barbels relatively short and flattened dorso-ventrally, and progressively tapering distally (Figs. 1-3). Tip of maxillary barbel extending to posterior limit of pseudotympanum or slightly beyond, but not reaching dorsal-fin origin. Tip of outer and inner mental barbels extending to region between middle and outer border of branchiostegal membrane. Outer mental barbel longer than inner barbel. Insertion of inner mental barbel slightly anterior to origin of outer mental barbel.

Dorsal fin distally rounded, not reaching to adipose fin when adpressed (Figs. 1-2). Dorsal fin with i,6 (21*)-7(3) rays. First dorsal-fin ray (spinelet) absent. Second dorsal-fin ray unbranched, entirely flexible, and segmented. Second dorsalfin ray slightly shorter than third and fourth rays (first and second branched rays, respectively), with tip falling short of tip of third dorsal-fin ray. Origin of dorsal fin distinctly anterior to pelvic-fin origin.

Pectoral fin with distal margin slightly convex, i,7 (3), 8 $\left(18^{*}\right), 9$ (3) rays. Proximal part of first ray rigid and with segmentation barely perceptible (25.8.0-50.6\% of its entire length, mean $=32.6 \%, \mathrm{SD}=7.5, \mathrm{~N}=20$ ), forming an almost straight, fragile spine; distal part of first ray usually longer, flexible, and clearly segmented. Rigid part of first pectoralfin ray lacking dentations. First pectoral-fin ray slightly shorter than second (first branched ray) and third (second branched ray) rays whose tips project slightly beyond tip of first ray. Pectoral fin lying parallel to main body axis when expanded and slightly directed upwards when adpressed to body.

Pelvic fin wide, with distal border rounded, i,5 rays $\left(23^{*}\right)$, rarely i,4 (1). Anterior portion of pelvic-fin base through third and fourth dorsal-fin rays (10), and fourth dorsal-fin ray $\left(14^{*}\right)$. Inner margins of pelvic-fin bases apart from each other. Tip of adpressed pelvic fin falling short of vertical through anal-fin origin. Lateralmost ray unbranched, completely flexible, segmented, and with tip distinctly falling short tips of second and third rays (first and second branched rays, respectively). 
Table 1. Morphometric features of Rhamdiopsis krugi, taken from: LIRP 5929 (holotype, Poço Encantado), LIRP 5930 (paratypes, Poço Encantado), MZUSP 92609 (paratypes, Poço Encantado), LIRP 5928 (paratypes, Lapa do Bode), and LIRP 5931 (paratype, Gruta Natal). Morphometric data 1-33 are expressed as percentage of standard length and 34-41 as percentage of head length. $\mathrm{H}=$ holotype; $\mathrm{N}=$ number of specimens; $\mathrm{SD}=$ Standard deviation.

\begin{tabular}{|c|c|c|c|c|c|c|c|c|c|c|c|c|c|c|c|c|c|}
\hline & \multicolumn{6}{|c|}{ Poço Encantado } & \multicolumn{5}{|c|}{ Lapa do Bode } & \multicolumn{2}{|c|}{ Gruta Natal } & \multicolumn{4}{|c|}{ TOTAL } \\
\hline & $\mathbf{H}$ & & $\begin{array}{l}\text { nge } \\
\text { max }\end{array}$ & mean & SD & $\mathbf{N}$ & $\begin{array}{c}\text { ran } \\
\text { min }\end{array}$ & $\begin{array}{l}\text { nge } \\
\text { max }\end{array}$ & mean & SD & $\mathbf{N}$ & & $\mathbf{N}$ & $\begin{array}{l}\text { ran } \\
\text { min }\end{array}$ & $\begin{array}{l}\text { nge } \\
\text { max }\end{array}$ & mean & SD $\mathbf{N}$ \\
\hline Total length (mm) & 43.3 & 25.1 & 43.3 & - & - & 11 & 25.7 & 38.6 & - & - & 8 & 40.0 & 1 & 25.1 & 43.3 & - & 20 \\
\hline Standard length (mm) & 37.1 & 20.4 & 37.1 & - & - & 11 & 20.8 & 32.4 & - & - & 8 & 34.9 & 1 & 20.4 & 37.1 & - & -20 \\
\hline 1. Predorsal length & 41.2 & 38.9 & 43.7 & 41.3 & 1.4 & 11 & 39.5 & 42.6 & 41.5 & 1.5 & 8 & 42.2 & 1 & 38.9 & 43.7 & 41.4 & 1.420 \\
\hline 2. Preanal length & 63.4 & 62.9 & 66.3 & 64.6 & 1.1 & 11 & 61.7 & 66.9 & 64.6 & 1.7 & 8 & 65.8 & 1 & 61.7 & 66.9 & 64.7 & 1.320 \\
\hline 3. Prepelvic length & 43.2 & 41.5 & 46.4 & 44.4 & 1.6 & 11 & 44.3 & 46.3 & 45.1 & 0.7 & 8 & 48.8 & 1 & 41.5 & 48.8 & 44.9 & 1.620 \\
\hline 4. Preadipose length & 64.7 & 64.2 & 69.4 & 66.1 & 1.7 & 11 & 62.6 & 70.0 & 66.5 & 2.5 & 8 & 69.1 & 1 & 62.6 & 70.0 & 66.4 & 2.120 \\
\hline 5. Caudal-peduncle length & 18.4 & 15.5 & 19.3 & 17.6 & 1.1 & 11 & 16.7 & 19.9 & 18.3 & 1.2 & 8 & 17.0 & 1 & 15.5 & 19.9 & 17.9 & 1.120 \\
\hline 6. Caudal-peduncle depth & 6.6 & 6.0 & 7.6 & 6.9 & 0.5 & 11 & 6.0 & 7.6 & 7.1 & 0.5 & 8 & 6.8 & 1 & 6.0 & 7.6 & 7.0 & 0.520 \\
\hline 7. Adipose-fin length & 25.8 & 25.5 & 28.7 & 27.3 & 1.3 & 11 & 28.0 & 30.7 & 29.1 & 0.9 & 8 & 24.4 & 1 & 24.4 & 30.7 & 27.9 & 1.620 \\
\hline 8. Adipose-fin depth & 3.7 & 2.8 & 3.9 & 3.3 & 0.3 & 11 & 3.4 & 4.1 & 3.7 & 0.3 & 8 & 2.8 & 1 & 2.8 & 4.1 & 3.4 & 0.420 \\
\hline 9. Dorsal fin to adipose fin & 15.1 & 12.1 & 16.2 & 14.1 & 1.3 & 11 & 11.8 & 16.0 & 14.4 & 1.5 & 8 & 15.7 & 1 & 11.8 & 16.2 . & 14.3 & 1.420 \\
\hline 10. Anal-fin base & 18.6 & 16.7 & 21.5 & 18.3 & 1.3 & 11 & 16.2 & 19.9 & 17.9 & 1.2 & 8 & 17.0 & 1 & 16.2 & 21.5 & 18.1 & 1.220 \\
\hline 11. Snout-anus distance & 49.2 & 49.0 & 52.6 & 50.5 & 1.3 & 11 & 48.8 & 53.0 & 50.5 & 1.6 & 8 & 53.0 & 1 & 48.8 & 53.0 & 50.6 & 1.420 \\
\hline 12. Snout-urogenital papilla distance & 51.4 & 51.9 & 56.4 & 53.6 & 1.5 & 11 & 52.1 & 55.5 & 53.9 & 1.2 & 8 & 57.5 & 1 & 51.9 & 57.5 & 53.9 & 1.620 \\
\hline 13. Anus-urogenital papilla distance & 2.5 & 2.0 & 4.6 & 2.8 & 0.8 & 11 & 2.5 & 4.4 & 3.2 & 0.7 & 8 & 2.8 & 1 & 2.0 & 4.6 & 3.0 & 0.720 \\
\hline 14. Length of first dorsal-fin ray (unbranched) & 11.4 & 10.6 & 15.7 & 13.0 & 1.5 & 11 & 11.1 & 14.8 & 13.1 & 1.1 & 8 & - & - & 10.6 & 15.7 & 13.0 & 1.319 \\
\hline 15. Length of second dorsal-fin ray (first branched) & 13.2 & 13.7 & 18.6 & 15.7 & 1.8 & 11 & 15.1 & 18.7 & 16.4 & 1.3 & 8 & - & - & 13.7 & 18.7 & 16.0 & 1.619 \\
\hline 16. Length of third dorsal-fin ray (second branched) & 15.0 & 14.4 & 18.7 & 16.1 & 1.3 & 11 & 15.3 & 18.3 & 16.8 & 0.8 & 8 & - & - & 14.4 & 18.7 & 16.4 & 1.219 \\
\hline 17. Dorsal-fin base & 12.0 & 11.5 & 14.1 & 12.4 & 0.8 & 11 & 11.2 & 13.3 & 12.0 & 0.8 & 8 & 12.2 & 1 & 11.2 & 14.1 & 12.2 & 0.820 \\
\hline 18. Length of first pectoral-fin ray (unbranched) & 11.1 & 11.0 & 14.8 & 12.9 & 1.3 & 11 & 12.1 & 14.0 & 13.1 & 0.7 & 8 & 12.0 & 1 & 11.0 & 14.8 & 13.0 & 1.120 \\
\hline 19. Length of rigid part of first pectoral-fin ray & 4.9 & 3.8 & 6.9 & 5.4 & 0.8 & 11 & 3.7 & 5.6 & 4.3 & 0.7 & 8 & 4.5 & 1 & 3.7 & 6.9 & 4.9 & 0.920 \\
\hline 20. Length of second pectoral-fin ray (first branched) & 13.4 & 13.4 & 16.7 & 14.5 & 1.0 & 11 & 13.3 & 16.1 & 14.6 & 0.9 & 8 & 13.2 & 1 & 13.2 & 16.7 & 14.5 & 1.020 \\
\hline 21. Length of third pectoral-fin ray (second branched) & 13.1 & 12.6 & 16.0 & 14.1 & 1.1 & 11 & 13.8 & 16.3 & 15.0 & 0.9 & 8 & 12.6 & 1 & 12.6 & 16.3 & 14.4 & 1.120 \\
\hline 22. Length of first pelvic-fin ray (unbranched) & 11.6 & 9.3 & 15.3 & 12.1 & 1.5 & 11 & 11.8 & 13.4 & 12.9 & 0.6 & 8 & 11.1 & 1 & 9.3 & 15.3 & 12.4 & 1.220 \\
\hline 23. Length of second pelvic-fin ray (first branched) & 12.9 & 11.6 & 15.6 & 13.7 & 1.2 & 11 & 13.7 & 15.6 & 14.6 & 0.6 & 8 & 12.4 & 1 & 11.6 & 15.6 & 14.0 & 1.120 \\
\hline 24. Length of third pelvic-fin ray (second branched) & 13.1 & 12.3 & 16.6 & 14.2 & 1.1 & 11 & 14.0 & 15.6 & 14.7 & 0.7 & 8 & 13.0 & 1 & 12.3 & 16.6 & 14.3 & 1.020 \\
\hline 25. Length of dorsal caudal-fin lobe & 17.7 & 17.4 & 22.9 & 19.6 & 1.4 & 11 & 19.1 & 21.3 & 20.3 & 0.9 & 8 & 17.5 & 1 & 17.4 & 22.9 & 19.8 & 1.320 \\
\hline 26. Length of ventral caudal-fin lobe & 16.9 & 15.8 & 20.7 & 18.5 & 1.3 & 11 & 18.1 & 20.8 & 19.3 & 1.0 & 8 & 17.4 & 1 & 15.8 & 20.8 & 18.8 & 1.220 \\
\hline 27. Body depth & 14.9 & 11.4 & 16.3 & 14.3 & 1.7 & 11 & 13.0 & 15.0 & 14.1 & 0.8 & 8 & 15.5 & 1 & 11.4 & 16.3 & 14.3 & 1.420 \\
\hline 28. Body width & 13.6 & 10.6 & 15.2 & 13.2 & 1.4 & 11 & 10.8 & 14.9 & 12.8 & 1.2 & 8 & 14.2 & 1 & 10.6 & 15.2 & 13.1 & 1.320 \\
\hline 29. Cleithral width & 17.3 & 17.3 & 20.0 & 18.6 & 0.9 & 11 & 18.7 & 19.7 & 19.2 & 0.3 & 8 & 20.7 & 1 & 17.3 & 20.7 & 18.9 & 0.820 \\
\hline 30. Maxillary-barbel length & 35.3 & 33.0 & 40.3 & 36.1 & 2.0 & 11 & 32.2 & 38.8 & 36.1 & 2.3 & 8 & - & - & 32.2 & 40.3 & 36.1 & 2.119 \\
\hline 31. Outer mental-barbel length & 14.1 & 14.1 & 21.6 & 18.5 & 2.3 & 11 & 16.8 & 22.8 & 19.7 & 2.1 & 8 & - & - & 14.1 & 22.8 & 19.0 & 2.219 \\
\hline 32. Inner mental-barbel length & 7.5 & 7.5 & 12.6 & 10.7 & 1.5 & 11 & 10.9 & 13.3 & 11.8 & 0.8 & 8 & - & - & 7.5 & 13.3 & 11.1 & 1.319 \\
\hline 33. Head length & 23.5 & 23.5 & 26.2 & 25.1 & 0.9 & 11 & 24.7 & 27.5 & 25.9 & 0.9 & 8 & 25.6 & 1 & 23.5 & 27.5 & 25.4 & 1.020 \\
\hline 34. Head depth & 49.7 & 45.3 & 51.5 & 48.1 & 3.1 & 11 & 40.9 & 53.8 & 46.2 & 4.3 & 8 & 53.8 & 1 & 40.9 & 53.8 & 47.6 & 3.920 \\
\hline 35. Head width & 74.0 & 70.8 & 79.2 & 75.9 & 3.2 & 11 & 64.7 & 81.4 & 75.2 & 5.1 & 8 & 84.1 & 1 & 64.7 & 84.1 & 76.0 & 4.320 \\
\hline 36. Bony interorbital & 20.4 & 20.4 & 29.7 & 23.9 & 2.7 & 11 & 20.2 & 25.2 & 22.5 & 1.6 & 8 & - & - & 20.2 & 29.7 & 23.3 & 2.420 \\
\hline 37. Distance between snout tip and posterior nare & 26.0 & 23.5 & 26.1 & 25.1 & 0.8 & 11 & 24.7 & 27.0 & 25.5 & 0.9 & 8 & 24.9 & 1 & 23.5 & 27.0 & 25.3 & 0.820 \\
\hline 38. Intranarial length & 14.1 & 11.7 & 14.0 & 12.6 & 0.7 & 11 & 10.2 & 13.3 & 12.1 & 1.0 & 8 & 12.6 & 1 & 10.2 & 14.0 & 12.4 & 0.920 \\
\hline 39. Anterior internarial width & 18.3 & 15.2 & 19.4 & 16.8 & 1.3 & 11 & 14.1 & 17.2 & 15.8 & 1.1 & 8 & 15.4 & 1 & 14.1 & 19.4 & 16.3 & 1.320 \\
\hline 40. Posterior internarial width & 16.6 & 15.8 & 19.6 & 16.8 & 1.0 & 11 & 15.5 & 17.2 & 16.2 & 0.6 & 8 & 15.8 & 1 & 15.5 & 19.6 & 16.5 & 0.920 \\
\hline 41. Mouth gape & 45.8 & 42.9 & 48.4 & 45.1 & 1.9 & 11 & 41.5 & 45.9 & 44.2 & 2.1 & 8 & 41.9 & 1 & 41.5 & 48.4 & 44.6 & 2.020 \\
\hline
\end{tabular}

Anal-fin very deep, its base of moderate size and its distal border rounded, supported by 13 (5), $14(10), 15(7), 16\left(1^{*}\right), 17$ (1) rays, including $8(3), 9(12), 10(6), 11(2 *)$ branched rays. Anal-fin rays with following branching pattern: v,8 (1), vi,8 (2), iv,9 (4), v,9 (7), vi,9(1), iv,10 (1), v,10 (4), vii,10 (1), iv,11 (1), $\mathrm{v}, 11\left(1^{*}\right)$. Two or three anteriormost anal-fin rays vestigial, unsegmented, embedded into thick anterior fold. Origin of anal-fin base just anterior to adipose-fin origin. End of analfin base slightly posterior to middle of adipose-fin base.

Adipose fin moderately long and low, forming ascending elevated curve in lateral profile, with highest point approximately at last third. Adipose fin merging gradually with back anteriorly, its origin difficult to pinpoint. Distance from dorsal fin to adipose fin greater than length of dorsal- fin base. Origin of adipose fin slightly posterior to middle of trunk, approximately on vertical through space between bases of second and third anal-fin rays $(2 *)$, base of third anal-fin ray (2), space between bases of third and fourth anal-fin rays (1). Posterior limit of adipose-fin base welldefined, with posterior lobe distinctly truncate, and its basal third fused to anterior portion of dorsal fold of caudal fin. Vertical through end of adipose-fin base distinctly posterior to distal tip of last anal-fin ray.

Caudal fin emarginate, with dorsal lobe slightly longer than ventral lobe. Dorsal lobe with 4 (1), 5 (3), 6 (19*), 7 (1) branched rays; ventral lobe with 4 (1), 5 (6), $6\left(17^{*}\right)$ branched rays. Total caudal fin-rays 31 (1), 32 (1), 33 (4), 35 (2), $36\left(5^{*}\right), 37(5), 38(1), 39(1), 40(3), 42$ (1); with 14 (1), 16 


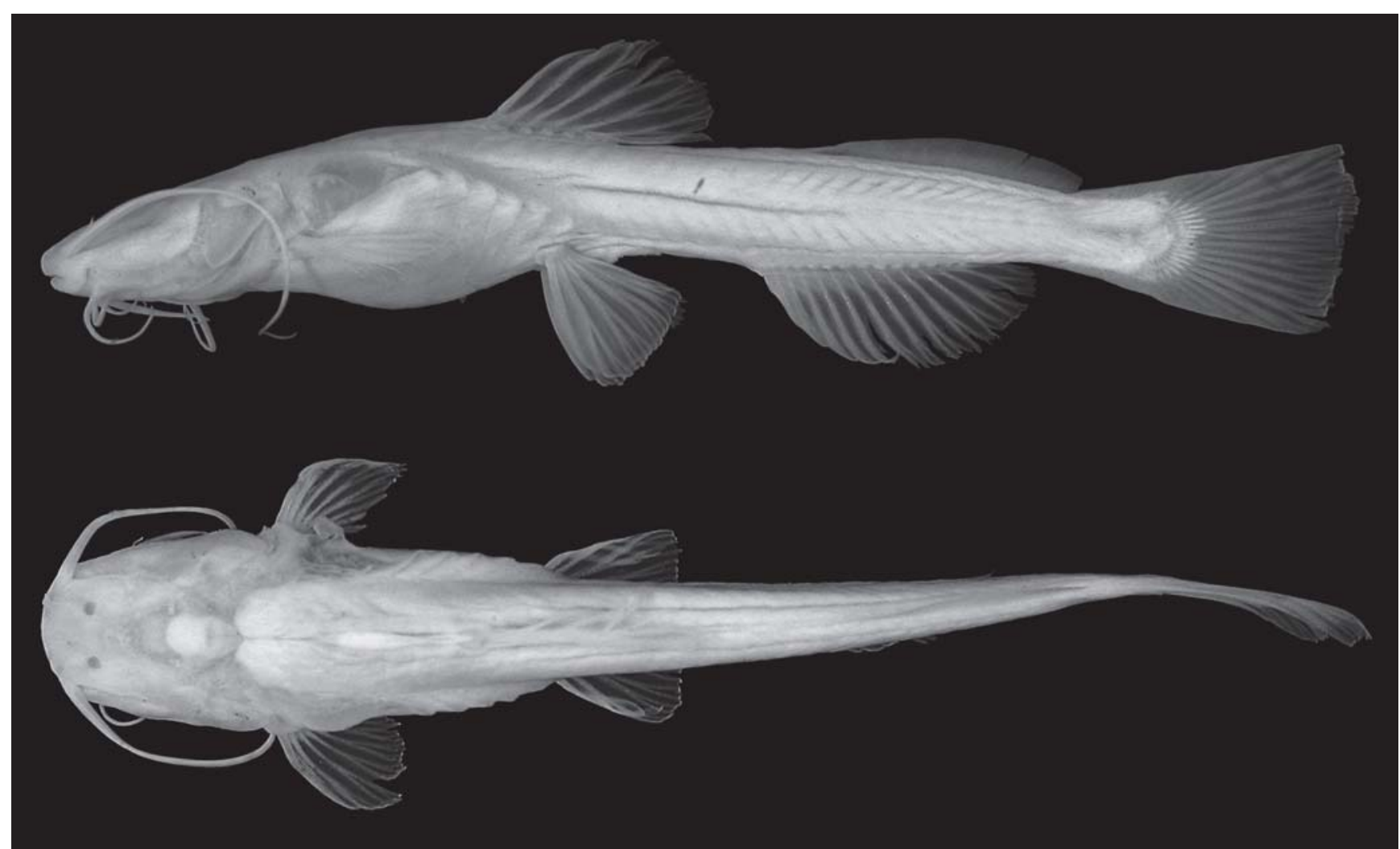

Fig. 1. Rhamdiopsis krugi, LIRP 5929, $37.1 \mathrm{~mm}$ SL, holotype; Poço Encantado cave, left margin of the rio Una, Municipality of Itaetê, State of Bahia, Brazil.

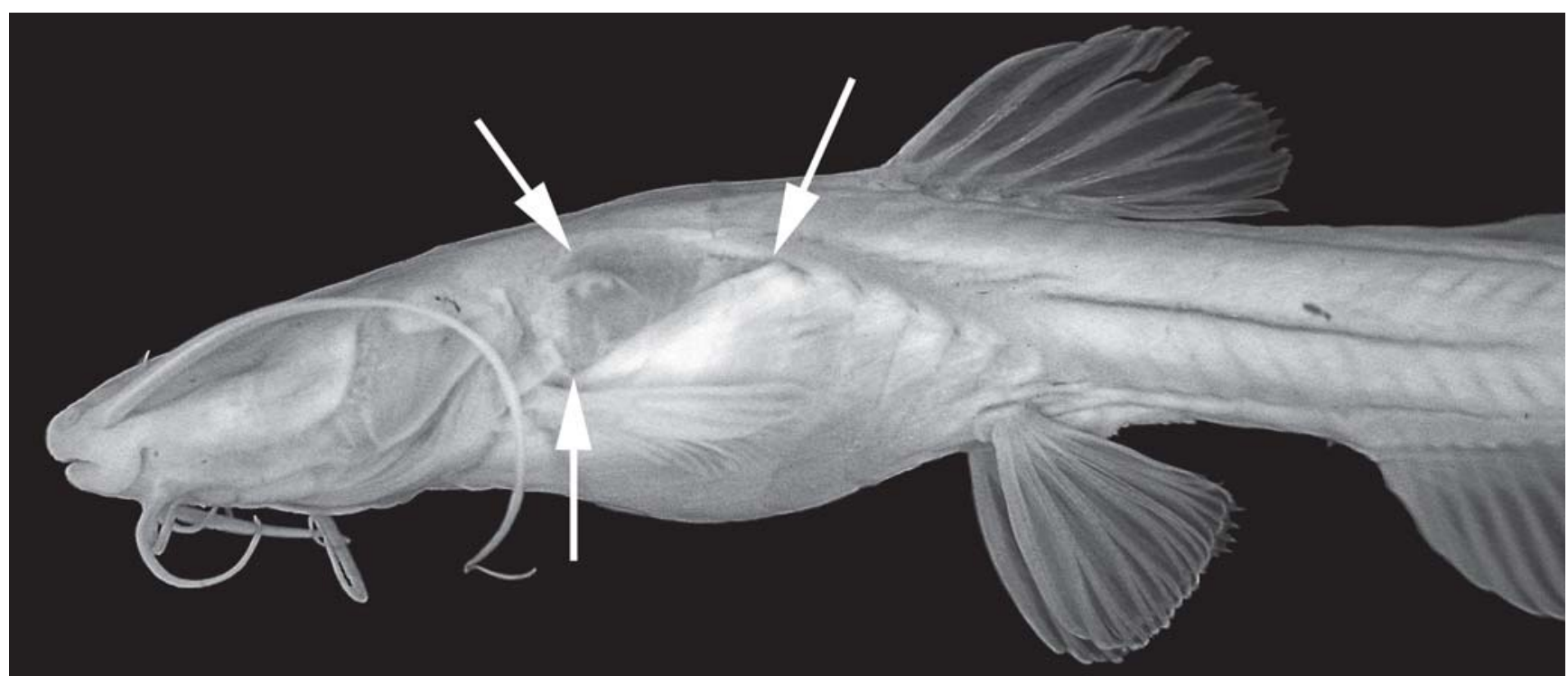

Fig. 2. Anterior portion of the body of Rhamdiopsis krugi, LIRP 5929, $37.1 \mathrm{~mm}$ SL, holotype. Arrows indicate the limits of the pseudotympanum.

(3), $17(4), 18\left(5^{*}\right), 19(5), 20(6)$ rays in dorsal lobe, and 15 $(1), 16(1), 17(6), 18\left(9^{*}\right), 19(3), 20(3), 22$ (1) rays in ventral lobe.

Laterosensory system (Figs. 3-4). Head sensory canals with simple (unbranched) tubes ending in single large pores. Supraorbital sensory canal continuous and connected to otic and infraorbital sensory canals posteriorly and, sometimes, to infraorbital anteriorly. Supraorbital sensory canal usually with five branches and pores: s1, s2, s3, s6 (epiphyseal branch and pore), and $\mathrm{s} 8$ (parietal branch and pore). Twenty two specimens with epiphyseal branches (s6) not fused to each other, each one bearing its own pore $\left(14^{*}\right)$ (Figs. $3 \mathrm{~b}, 4 \mathrm{a})$, and one single specimen with epiphyseal branches 


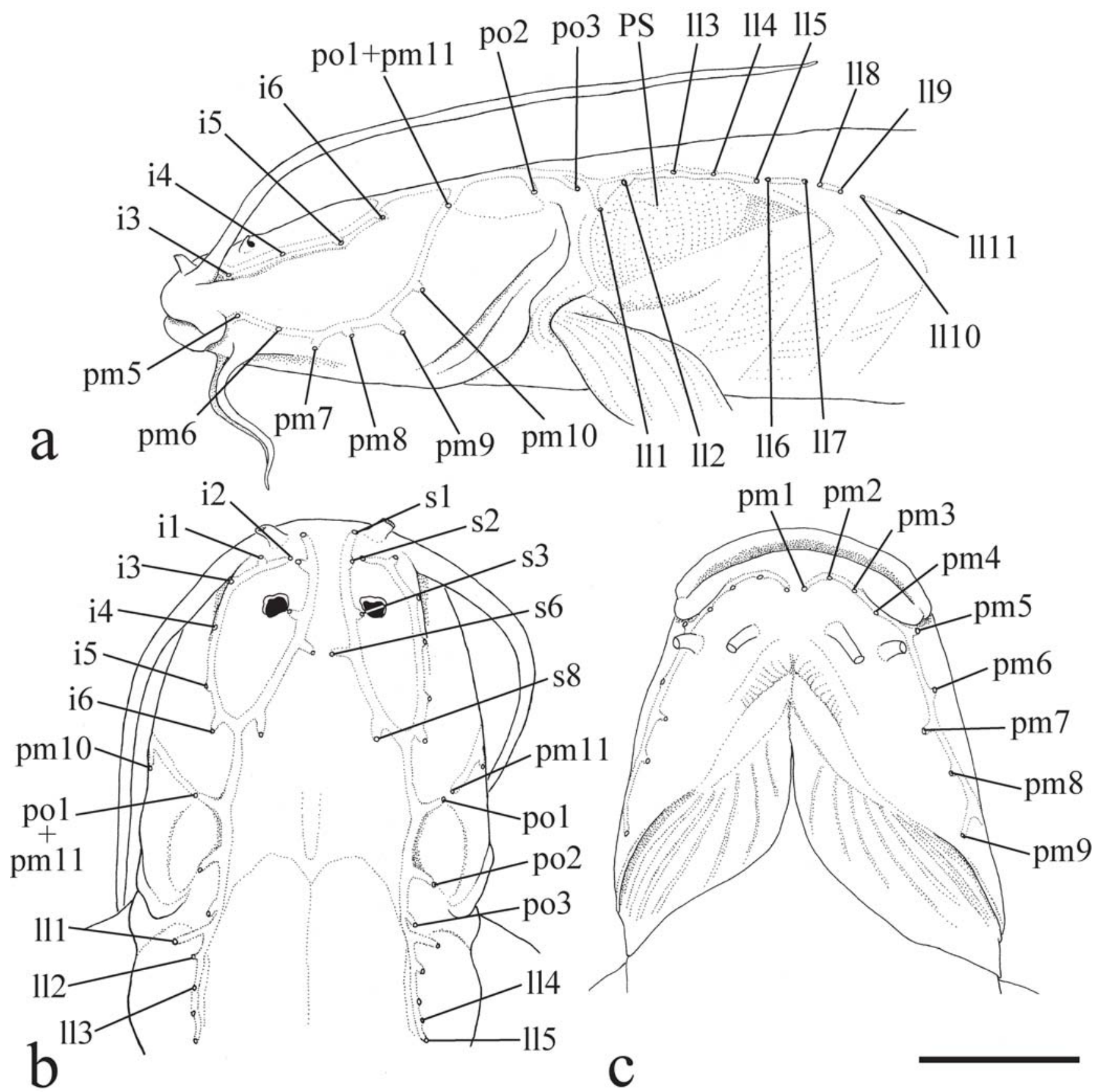

Fig. 3. Anterior portion of the body of Rhamdiopsis krugi, LIRP 5929, $37.1 \mathrm{~mm}$ SL, holotype, showing laterosensory canal system. a) lateral view; b) dorsal view; c) ventral view. i1) infraorbital sensory branch 1; i2) infraorbital sensory branch 2 (antorbital branch); i3-6) infraorbital sensory branches 3 to 6; ll1) lateral line sensory branch 1; l12-11) lateral line sensory branches 2 to 11; pm1-11) preoperculomandibular sensory branches 1 to 11 ; po1) postotic sensory branch 1; po1+pm11) postotic-preoperculomandibular complex sensory branch (postotic sensory branch $1+$ preoperculomandibular sensory branch 11); po2) postotic sensory branch 2 (pterotic or temporal branch); po3) postotic sensory branch 3; s1-3) supraorbital sensory branches 1 to 3; s6) supraorbital sensory branch 6 (epiphyseal branch); and s8) supraorbital sensory branch 8 (parietal branch). Scale bar $=3 \mathrm{~mm}$.

fused to each other, bearing single symphyseal pore $(\mathrm{s} 6+\mathrm{s} 6)$. Presence of $\mathrm{s} 7$ branch and pore (postorbital) variable: present on both head sides in five specimens (Fig. 4a), present on one head side only in 8 specimens, and absent on both head sides in $10\left(^{*}\right)$ specimens (Fig. 3b). S4 and s5 branches and pores absent. Supraorbital and infraorbital sensory canals anteriorly connected to each other through s2 and i2 branches (forming complex $\mathrm{s} 2+\mathrm{i} 2$ pore) or not, varying both bilaterally and intraspecifically: $10(*)$ specimens with unfused pores on both sides of head (Figs. 3b, 4a); 6 specimens with unfused pore on one head side only; 8 specimens with fused pores on both sides. Otic sensory 
canal short, without pores, and continuous with posterior limits of supra- and infraorbital sensory canals, anteriorly, and with anterior limit of postotic sensory canal, posteriorly. Postotic (or temporal) sensory canal extends from posterior limit of otic sensory canal to anterior limit of lateral line, with 3 branches and pores (po1, po2, and po3). Twenty two specimens with po1 branch and pore independent from posteriormost branch and pore of preoperculomandibular sensory (pm11) on both sides of head; one specimen $(*)$ with pol and pm11 branches fused on one side of head, forming po1+pm11 complex pore, and unfused on other side (Fig. 3a-b). Infraorbital sensory canal with six branches and pores, with s2 independent from i2 or not (see above). Preoperculomandibular sensory canal with 11 branches and pores; anteriormost preoperculomandibular sensory branch (pm1) not fused to its antimeric branch. Lateral line sensory canal continuous with postotic sensory canal anteriorly. Lateral line sensory canal short, with posterior limit extending from vertical through middle of pectoral fin to vertical through end of dorsal-fin base (usually from vertical through posterior limit of pseudotympanum to vertical through dorsal-fin origin), with 5-15 pores: 3-6 (usually 4-5) anteriormost pores in long and continuous patch above pseudotympanum and 1-4 short patches (usually 1-2) of 2-4 pores (usually 2) more spaced from each other caudally. First lateral line pore below level of adjacent pores of lateral line. Intervals between adjacent branches of lateral line surrounded by tubular ossicles.

Internal morphology. Cranial roof bones mostly smooth, devoid of ornamentation (Fig. 4). Frontals, supraoccipital, pterotics, and sphenotics joined to each other through distinct dentate sutures. Bony interorbital width broad, with orbital region poorly defined in dorsal view, demarcated by discrete concavity on outer border of frontal. Cranial fontanels completely opened and separated by conspicuous epiphyseal bar; anterior fontanel shorter and wider than posterior one. Anterolateral cornua of mesethmoid concave anteriorly, delimiting shallow median anterior cleft. Tip of posterolateral cornua of mesethmoid laterally directed and blunt, not forming typical mesethmoid hook (Lundberg \& McDade, 1986). Anterior portion of lateral ethmoid (which accommodates olfactory organ) approximately as long as posterior one. Posterolateral corner of lateral ethmoid short and blunt. Cartilage between posterior border of mesethmoid and anterior margin of lateral ethmoids discontinuous on both sides of two c\&s specimens (Fig. 4), discontinuous on one side of one c\&s specimen (but with weak chondrification where interruption is expected), and continuous on both sides in one c\&s specimen. Lateral ethmoid-orbitosphenoid joint synchondral, without interdigitating sutures. Lateral margin of frontal roughly straight or slightly concave. Sphenotic nearly as long as pterotic. Nasal long, thin and spongy. Antorbital rod-like, with dorso-medial lamina weakly ossified. Infraorbital laterosensory canal comprising 5 tubular ossifications: antorbital tubule and four suborbitals.
Infraorbital bone series straight, approximately parallel with lateral border of posterior portion of cranium. Antorbital tubule transversally attached to dorsal surface of anteromesial portion of antorbital bone. Suborbital 1 obliquely co-ossified with dorsal surface of anterolateral portion of antorbital bone. Posteriormost end of infraorbital canal at frontal-sphenotic joint. Extrascapula triangular, transversally oriented, and solidly attached to posterolateral region of cranium. Supraoccipital process narrow and short, barely reaching posteriormost limit of basioccipital. Posterior process of epioccipital for articulation of dorsal limb of cleithrum very prominent.

Vomer elongate, expanded anteriorly but with attenuate lateral processes. Optic nerve foramen as small vertical slit framed by orbitosphenoid anteriorly and by parasphenoid posteriorly. Trigeminofacial nerves foramen very large, horizontally elongate, and bordered by pterosphenoid anteriorly and anterodorsally, by sphenotic posterodorsally, by parasphenoid anteroventrally, and by prootic posteroventrally.

Premaxilla rectangular, short and wide, its posterolateral corner rounded, not projecting (Fig. 4). Maxilla small, with distal, complete tubule around base of maxillary-barbel core. Autopalatine elongate, with large conical cartilages caps at extremities. Dentary with smooth contour in dorsal view, with no anterior shelf-like projection.

Entopterygoid thin, roughly quadrangular; ligamentously attached to anterior margin of metapterygoid (Fig. 5). Metapterygoid roughly quadrangular, about twice larger than entopterygoid. Metapterygoid-quadrate joint suturally interdigitated dorsally, centrally synchondral, and ventrally the bones are separated by a gap. Metapterygoidhyomandibula joint absent. Quadrate pedunculate, its dorsal margin free; quadrate-hyomandibula joint suturally interdigitated dorsally, centrally synchondral; quadrate attached to preopercle postero-ventrally. Foramen for ramus mandibularis externus facialis of hyomandibular nerve trunk (MFen) located at boundary between posteroventral margin of quadrate and anterodorsal portion of first third of preopercle. Anterodorsal margin of hyomandibula smoothly rounded, with bony outgrowths incipient. Posterodorsal hyomandibular process for insertion of levator operculi muscle triangular and large. Lateral wall of hyomandibula with three nerve foramina: a small, rounded opening (IF; possibly a rudimentary infraorbital foramen), located near anterodorsal margin of bone; a large, elongate opening for exit of hyomandibular trunk (HMex), located approximately at mid portion of bone; and a large and rounded opening for entrance of ramus hioideus of hyomandibular trunk (HFen), located on hyomandibula-preopercle joint. Preopercle laterally concave, articulating with ventral margin of quadrate anterodorsally and anteroventral border of hyomandibula posterodorsally. Subpreopercle and suprapreopercle ossicles absent. Opercle large, triangular, with lateral surface mostly smooth. Interopercle triangular, distinctly pointed anteriorly. 

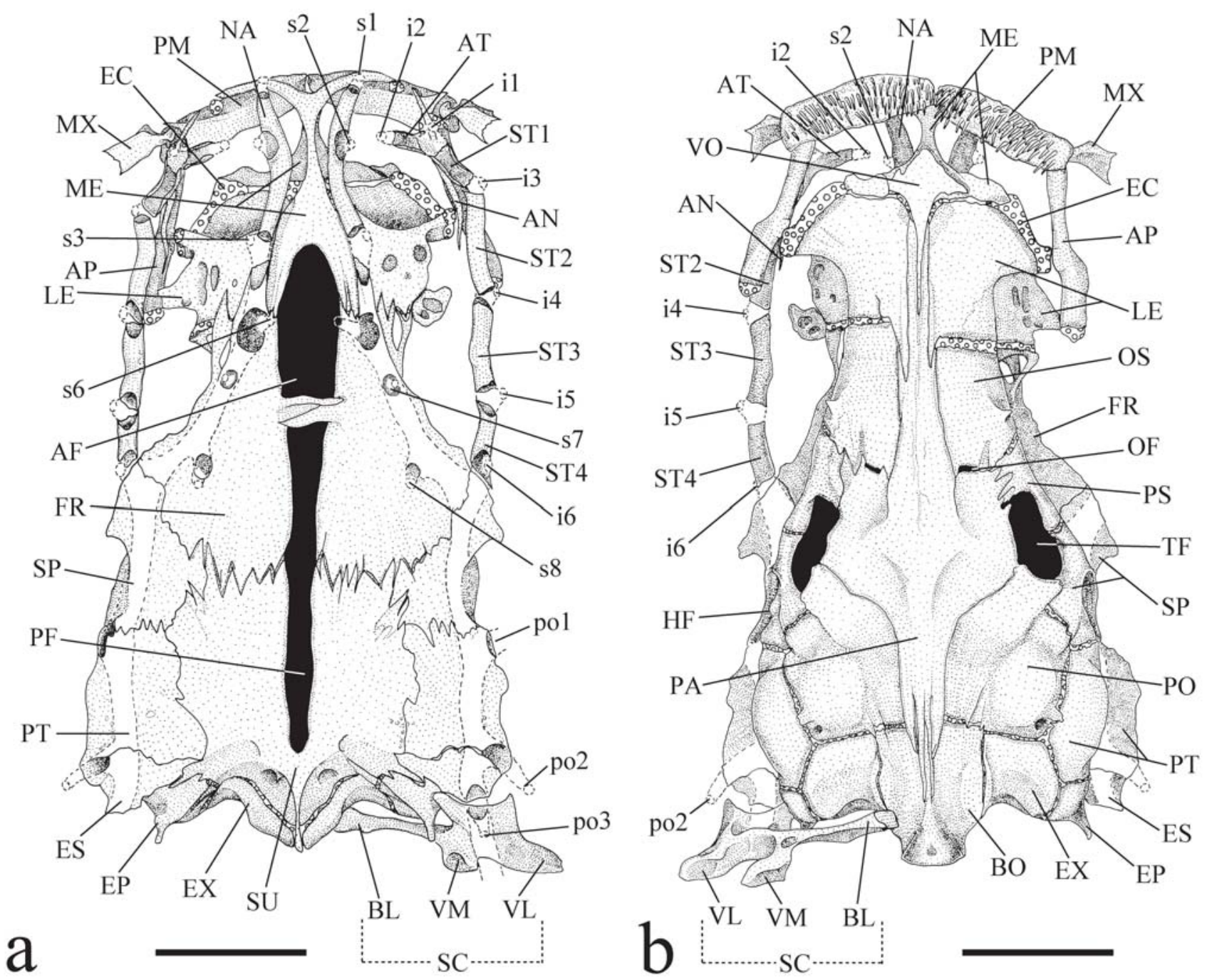

Fig. 4. Cranium of Rhamdiopsis krugi, LIRP 5928, $33.9 \mathrm{~mm} \mathrm{SL}$, paratype. a) dorsal view; b) ventral view. Abbreviations: AF) anterior fontanel; AN) antorbital; AP) autopalatine; AT) antorbital tubule; BL) Baudelot's ligament; BO) basioccipital; EC) ethmoidean cartilage; EP) epioccipital; ES) extrascapula; EX) exoccipital; FR) frontal; HF) hyomandibular facet; i1-6) infraorbital sensory branches 1 to 6; LE) lateral ethmoid; ME) mesethmoid; MX) maxilla; NA) nasal; OF) optic foramen (rudiment); OS) orbitosphenoid; PA) parasphenoid; PF) posterior fontanel; PM) premaxilla; PO) prootic; po1-3) postotic sensory branches 1 to 3; PT) pterotic; PS) pterosphenoid; s1-3) supraorbital sensory branches 1 to 3; s6) supraorbital sensory branch 6 (epiphyseal branch); s7) supraorbital sensory branch 7 (postorbital branch); s8) supraorbital sensory branch 8 (parietal branch); SC) supracleithrum; SP) sphenotic; ST1-4) suborbital tubules 1 to 4; SU) supraoccipital; TF) trigeminofacial foramen; VL) ventrolateral limb of supracleithrum; VM) ventromedial limb of supracleithrum; and VO) vomer. Scale bars $=1.5 \mathrm{~mm}$.

Supracleithrum and Baudelot's ligament totally co-ossified (Fig. 4). Ventrolateral and ventromedial limbs of supracleithrum not distally connected. Ventromedial limb with facet for articulation of anterior branch of transverse process 4. Proximal extremity of Baudelot's ligament completely ossified except for ligamentous attachment to basioccipital and exoccipital.

Lateral surface of hyoid arch convex, with conspicuous shelf from posterior portion of ventral hypohyal to about midlength of anterior ceratohyal; medial surface excavated. Dorsal hypohyal diminutive, ventral hypohyal large. Anteriorposterior ceratohyal joint synchondral and weakly intergiditated; mesial dentate suture absent. Interhyal nodular, completely ossified. Hyoid arch with 6 (17*)-7 (7) branchiostegal rays: 5-6 on ventral border of anterior ceratohyal, 1 or none on inter-ceratohyal cartilaginous joint, and 1 on ventral border of posterior ceratohyal. Urohyal triangular, with dorsal keel reaching approximately region between ossified portions of basibranchials 2 and 3 .

Basibranchial 1 absent. Basibranchials 2 and 3 united to each other, as long, continuous rod, with anteriormost portion on dorsal surface of urohyal keel and posterior tip in front of anteromedial region of hypobranchials 3 (Fig. 6) or in middle of these elements. Ossification of basibranchial 2 approximately as long as bony portion of hypobranchial 1, or slightly longer. Ossification of basibranchial 3 less than half size of ossification of basibranchial 2 and absent in one of 
four c\&s specimens. Basibranchial 4 cartilaginous, with hexagonal dorsal plate and elongate ventral rod. Hypobranchial 1 wide and largely ossified, with cartilage at extremities. Anterodistal margin of hypobranchial 1 with discrete osseous prominence (uncinate process absent). Hypobranchial 2 long, approximately square, largely ossified (3 specimens), and with continuous cartilaginous sheet along posterior border. One specimen with left hypobranchial 2 with small ossification at anterolateral corner and right hypobranchial 2 completely cartilaginous. Anterodistal region of hypobranchial 2 with anterolaterally-oriented process. Hypobranchial 3 cartilaginous; its anterolateral corner with distinct projection. Hypobranchial 4 absent. Ceratobranchials largely ossified except at extremities. Ceratobranchials 1-4 mostly straight. Ceratobranchials 1-2 of uniform width along their entire lengths; ceratobranchials 3-4 slightly wider proximally than at their midpoints. Proximate cartilaginous head of ceratobranchial 4 long, laterally straight. Ceratobranchial 5 with posteromedially expanded toothplate bearing 4-6 irregular rows of small conical teeth, all approximately of similar size; most medial row with 13-20 teeth. Epibranchials 1-4 rod-like, largely ossified except at extremities. Posterior border of epibranchial 3 with long uncinate process overlapping epibranchial 4. Anterior and posterior borders of epibranchial 4 with broad crests. Fifth epibranchial nodular, completely cartilaginous, and associated with distal cartilaginous end of ceratobranchial 4 . Pharyngobranchials 1 and 2 absent. Pharyngobranchial 3 rod-like, widely ossified (except at tips), with shallow medial crest (lateral crest absent) and posterior tip distinctly expanded. Pharyngobranchial 4 quadrangular, almost completely ossified. Accessory cartilaginous nodule between inner tips of epibranchials 1-2 and anterior extremity of pharyngobranchial 3 . Pharyngobranchials 1 and 2 absent. Upper pharyngeal tooth plate large, with 31-48 small conical teeth (larger specimens with more teeth).

Dorsal-fin rays supported by seven blade-like pterygiophores. Proximal tip of first pterygiophore of dorsal fin between bifid neural spine of vertebra $9\left(20^{*}\right)$ or space between neural spines of vertebrae 9-10 (4). Proximal tip of last pterygiophore of dorsal fin between spaces of pseudoneural spines (see below) of vertebrae 13-14 (17*), or vertebrae 14-15 (7). Supraneural and anterior nuchal absent. Distal extremity of first pterygiophore slightly expanded and with posterior slender projections, but not forming typical middle nuchal plate. Distal extremity of second pterygiophore expanded anterolaterally, but not forming typical posterior nuchal plates. Dorsal-fin pterygiophores 1 and 2 adjacent to each other, and distally sutured.

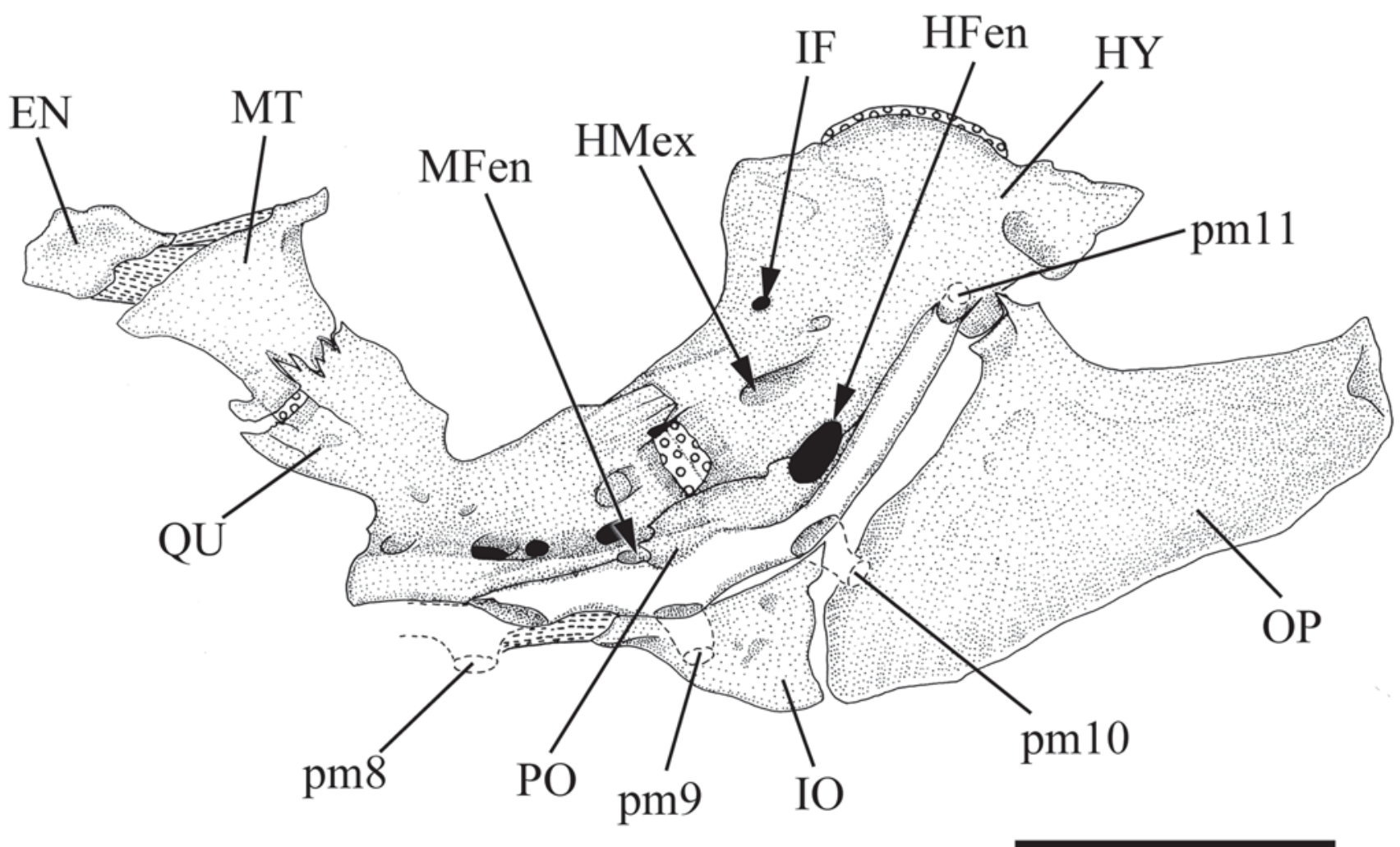

Fig. 5. Left suspensorium and opercular series of Rhamdiopsis krugi, LIRP 5928, 33.9 mm SL, paratype. Lateral view. EN) entopterygoid; HFen) foramen for entrance of ramus hyoideus of hyomandibular nerve trunk; HMex) foramen for exit of hyomandibular nerve trunk; HY) hyomandibula; IF) foramen for exit of infraorbital trunk nerve; IO) interopercle; MFen) foramen for entrance of ramus mandibularis externus facialis of hyomandibular nerve trunk; MT) metapterygoid; OP) opercle; pm8-11) preoperculomandibular sensory branches 8 to 11; PO) preopercle; and QU) quadrate. Scale bar=1.5 mm. 


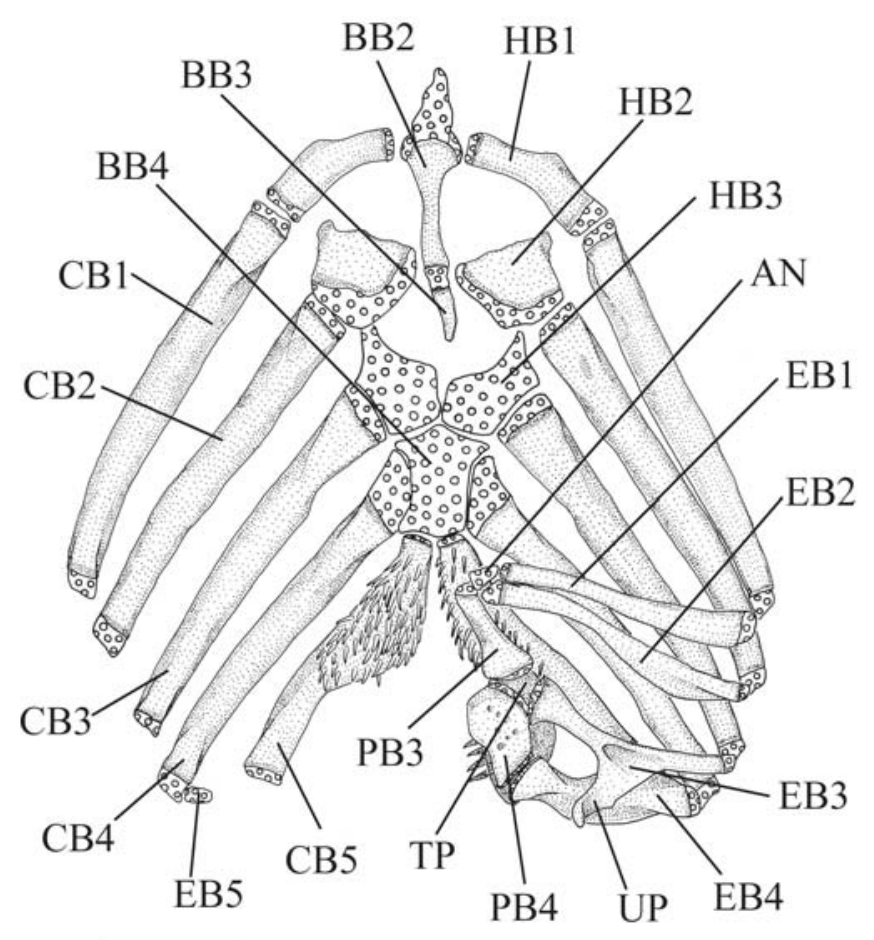

Fig. 6. Gill arches of Rhamdiopsis krugi, LIRP 5928, $33.9 \mathrm{~mm}$ SL, paratype. Dorsal view. Gill rakers and dorsal elements of left gill arches not shown. AN) accessory cartilaginous nodule; BB2-4) basibranchials 2 to 4; CB1-5) ceratobranchials 1 to 5; EB1-5) epibranchials 1 to 5; HB1-3) hypobranchials 1 to 3; PB3-4) pharyngobranchials 3 and 4; TP) tooth plate; and UP) uncinate process. Scale bar $=0.5 \mathrm{~mm}$.

Centrum 1 autogenous, disc-like, firmly attached to basioccipital and complex vertebra. Joint between complex vertebra (vertebrae 2 to 4 ) and vertebra 5 interdigitated. Joint between vertebrae 5 and 6 symphyseal. Dorsal margin of vertical lamina of complex vertebra low and straight. Neural spine of vertebra 4 vertical, not covering neural spine of vertebra 5, or slightly inclined posteriorly, covering anterior portion of neural spine of vertebra 5 (Fig. 7). Transverse process of vertebra 4 sharply divided by notch into anterior and posterior branches. Anterior branch of transverse process of vertebra 4 wide, ventrolaterally oriented, and covering anterior portion of swimbladder. Distal portion of posterior branch of transverse process of vertebra 4 laminar, wide, laterally expanded. Anterior portion (arborescent portion) of posterior branch of transverse process of vertebra 4 with spatulat in form (not divided into two main arms by notch, except for one c\&s specimen on one side). Posterior portion of posterior branch of transverse process of vertebra 4 triangular, with posterolateral corner reaching approximately to midlength of transverse process of vertebra 5. Posterior border of anterior branch and anterior margin of arborescent portion of posterior branch of transverse process of vertebra 4 joined to each other via bony bridge (Fig. 7, see arrow). Distal extremity of transverse process of vertebra 5 slightly expanded and unbranched. Ascending process of scaphium absent and posterior portion of transformator process of tripus thick, rounded, and medially directed.

Swimbladder large, transversely bilobed, and foreshortened to anterior body cavity, extending posteriorly to $6^{\text {th }}(1)$ to $7^{\text {th }}(3)$ vertebral centra.

Ascending limb of cleithrum articulating between ventrolateral and ventromedial limbs of supracleithrum (Figs. 8-9). Postcleithral process short, triangular, with extremity posteriorly directed. Mesocoracoid arch wide, complete. Cleithra united to each other on ventral midline by a ligamentous joint as long as the midline joint between paired coracoids. Anterior margin of cleithrum straight or concave near midline, then broadly convex laterally. Coracoids interlocked by two sutural dentations. Coracoid keel shallow, with posteroventral process absent. Proximal radials 1 and 2 rod-like, distally expanded, and completely ossified except for cartilaginous extremities; proximal radial 2 slightly longer than proximal radial 1 and with distal tip wider. Three main distal radials present. First distal radial (complex distal radial) massive, triangular, with anterior portion fit into cavity of base of first pectoral-fin ray (unbranched ray). Complex distal radial ossified at its anterior portion in three c\&s specimens and completely cartilaginous in one c\&s specimen. Posterior portion of complex distal radial supporting second pectoral-fin ray (first branched ray). First distal radial (DR1) medium-sized, completely cartilaginous, quadrangular, undivided, and supporting third pectoral-fin ray (second branched ray). Second distal radial (DR2) large, trapezoid, totally cartilaginous, and supporting three (fourth, fifth, and sixth pectoral-fin rays), rarely two pectoral-fin rays. Second distal radial limited by first distal radial anteriorly, by first proximal radial mesially, and by second proximal radial posteriorly. Second distal radial divided into two pieces of variable sizes and shapes: anteriormost cartilage (DR2a) supporting fourth pectoral-fin ray; and posteriormost piece (DR2b) supporting fifth and sixth pectoral-fin ray. Sometimes, posterior piece of second distal radial has a small posterior nodule (DR2c) to support sixth ray. Last 3-4 rays articulated with distal extremity of proximal radial 2.

External and internal anterior processes of basipterygium long (Fig. 10). External anterior process narrow, slightly slender at anterior osseous extremity; its anterior cartilage small, slightly expanded laterally. Internal anterior process of basipterygium shorter and wider than external anterior process, with small anterior cartilage, and adjacent to its counterpart anteriorly. Lateral margin of posterior process of basipterygium medially sloped at about $45^{\circ}$. Bony portion of posterior process of basipterygium long, about 0.3 times of main body of bone. Cartilaginous portion of posterior process of basipterygium short, with vertex pointed but not prolonged posteriorly. Medial cartilage of paired basipterygia fused on ventral midline. Lateral posterior cartilages of basipterygium distinctly separated from cartilage of posterior process of basipterygium. Pelvic splint and radials absent. Site of insertion of first pelvic-fin ray on basipterygium below region from vertebral centra 12 to 14 , with variation as follows: between centra 12-13 (2), centrum 13 (12*), between centra 13-14 (9), and centrum 14 (1). 


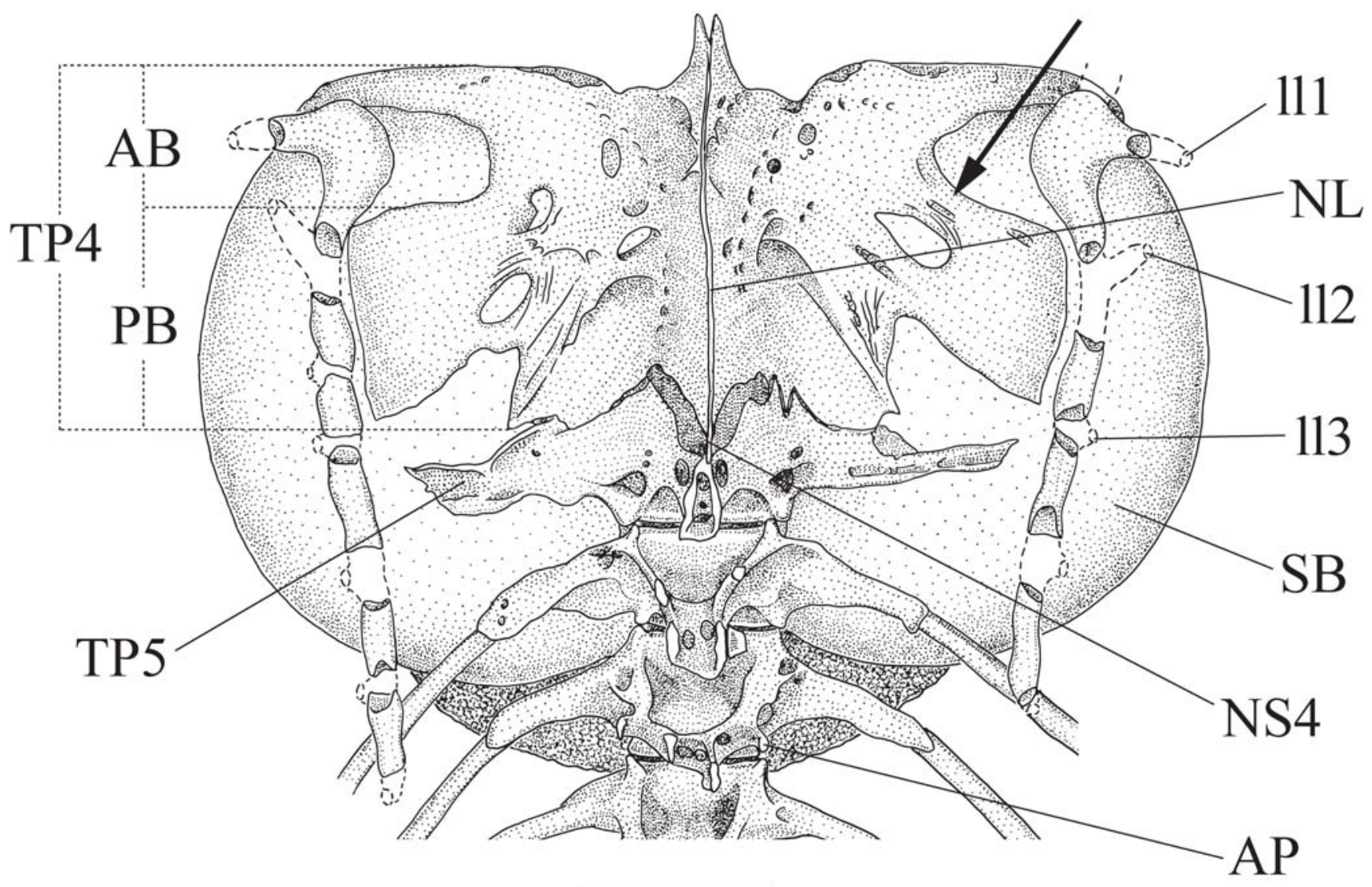

Fig. 7. Anterior vertebrae of Rhamdiopsis krugi, LIRP 5928, $33.9 \mathrm{~mm}$ SL, paratype. Dorsal view. AB) anterior branch of transverse process 4; AP) accessory process of vertebra 7; II1-3) lateral line sensory branches 1 to 3; NL) neural lamina (neural arches of vertebrae 3 and 4); NS4) neural spine of vertebra 4; PB) posterior branch of transverse process 4; SB) swimbladder; TP4) transverse process 4; and TP5) transverse process 5. Arrow indicates osseous bridge joining anterior and posterior branches of transverse process 4 . Scale bar $=2 \mathrm{~mm}$.

Origin of adipose-fin base above region from vertebral centra 22 to 25 , usually $22-24$, with variation as follows: centrum 22 (3), between centra $22-23(5)$, centrum $23\left(4^{*}\right)$, between centra 23-24 (4), centrum 24 (7), and centrum 25 (1). End of adipose-fin base above region from vertebral centra 34 to 38 , usually $35-37$, with variation as follows: centrum 34 (2), centrum $35\left(10^{*}\right)$, between centra 35-36 (1), centrum 36 (6), between centra 36-37 (3), centrum 37 (1), and centrum 38 (1).

Tip of first pterygiophore of anal fin between hemal spines of vertebrae 18-19 (1), 19-20 (1), 20-21 (14*), and 21-22 (7). Tip of last pterygiophore of anal fin between hemal spines of vertebrae 27-28 (4), 28-29 (12*), and 29-30 (7).

Parhypural wide proximally and tapering towards tip; totally fused to hypurals 1 and 2 but with dorsal limit perceivable by discrete suture line (Fig. 11). Hypurals 1 and 2 completely co-ossified into single ventral caudal plate, without any vestige of suture. Hypurals 3 and 4 completely fused to each other. Most specimens with hypural 5 partially coossified to hypural 4 (usually at its distal portion only) (16*) (Fig. 11a), rarely co-ossified with this element into single dorsal caudal plate (2) (Fig. 11b) or totally autogenous (4). Epural single, rod-like, autogenous; its distal tip cartilaginous. Dorsal and ventral caudal plates separated from each other (except at their bases), but very near distally through bony outgrowths. Hypurapophysis and secondary hypurapophysis fused, forming a continuous horizontal shelf (complex hypurapophysis), extending to base of hypural 2 (hypurapophysis "type C" of Lundberg \& Baskin, 1969). Dorsal hypural plate with $7\left(22^{*}\right)$, rarely $6(1)$ and 8 (1) rays. When distal limit of hypural 5 is discernible, dorsal caudal rays arranged as follows: 3 rays on hypural $3+4$ and 4 rays on hypural 5 (12), 4 rays on hypural $3+4$ and 3 rays on hypural 5 (8), and 3 rays on hypural $3+4$ and 3 rays on hypural 5 (1). Caudal rays on dorsal plate with following branching pattern: i,6 (19*), rarely ii,4 (1), ii,5 (3), and i,7 (1) rays. Ventral caudal plate (parhypural plus hypurals 1 and 2) with 6 (17), less commonly $7\left(7^{*}\right)$ rays. Caudal rays on ventral plate with following branching pattern: $6(12)$, less commonly i, $6\left(5^{*}\right)$, i,5 (4), ii, 5 (2), ii, 4 (1) rays. Bases of middle caudal-fin rays (lowermost ray of dorsal caudal-fin lobe and uppermost ray of ventral caudal-fin lobe) articulate directly to caudal plates. Middle caudal-fin rays branched and similar to other caudalfin rays, without marginal expansions. Distal border of parhypural and hypurals cartilaginous. Distal extremity of 


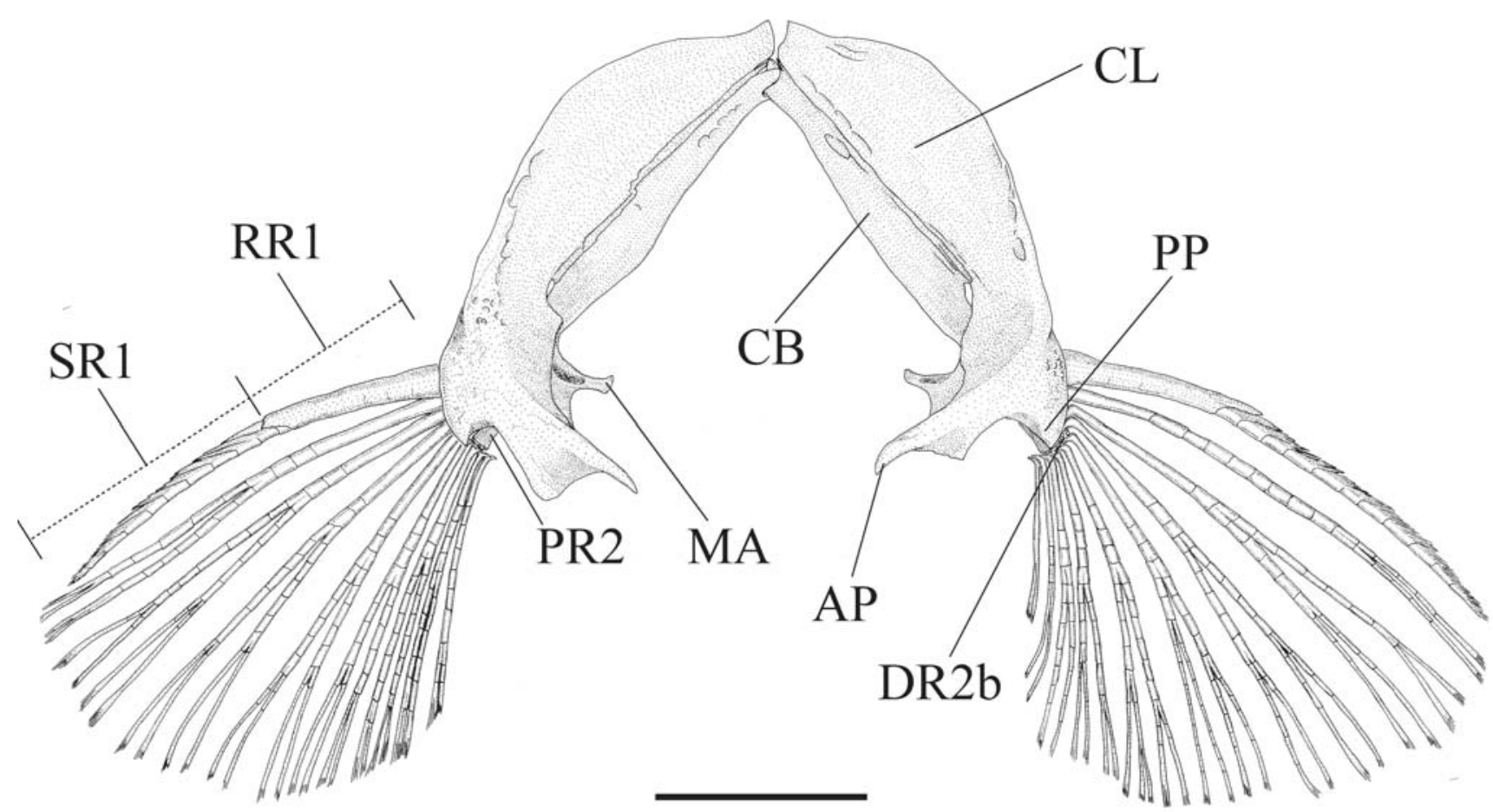

Fig. 8. Pectoral girdle and fins of Rhamdiopsis krugi, LIRP 5928, $33.9 \mathrm{~mm}$ SL, paratype. Dorsal view. AP) articular cleithral process; CB) posterior complex bone of pectoral girdle (scapula, coracoid, and mesocoracoid fused); CL) cleithrum; DR2b) main posterior piece of distal radial 2; MA) mesocoracoid arch; PP) postcleithral process; PR2) proximal radial 2; RR1) rigid part of pectoral-fin ray 1; and SR1) soft part of pectoral-fin ray 1 . Scale bar $=2 \mathrm{~mm}$.

neural and hemal spines of last free vertebra (preural centrum 2) cartilaginous. Distal extremity of neural spine of penultimate free vertebra (preural centrum 3) cartilaginous or ossified; distal extremity of hemal spine of penultimate free vertebra (preural centrum 3) cartilaginous. Distal extremity of hemal spine of antepenultimate free vertebra (preural centrum 4) cartilaginous or ossified.

Total vertebrae $38(5), 39\left(11^{*}\right), 40(8)$. Neural spines of vertebrae extend dorsally, but do not reach skin. Neural spines of fifth vertebra of Weberian apparatus to $6-7^{\text {th }}$ free vertebra (11$12^{\text {th }}$ total vertebra, respectively) bifid. Neural spines are progressively lower on more posterior vertebrae. All anteriormost free vertebrae with vertically-oriented accessory process (AP) at anterior region of neural arch base (Fig. 7). Paired accessory processes progressively deeper and closer to each other on posterior vertebrae, forming pseudoneural spines, whereas neural spines progressively lower backwards. Neural spine incipient at 4-5th free vertebra (9-10th total vertebra) and absent from 6-7th free vertebra (11-12th total vertebra, respectively), with accessory processes replacing them on middorsal region of vertebral centra. Pleural ribs 7 (3), $8\left(12^{*}\right)$, and 9 (8) pairs. Distal extremities of pleural ribs tapered. Rib-bearing parapophysis long and with a spoon-like distal area for articulation of ribs. First complete (i.e., not bifid distally) hemal spine on vertebrae $15\left(13^{*}\right)-16(11)$. Neural and hemal spines of caudal vertebrae mostly straight, with no conspicuous basal process. Neural spine of vertebra in middle of caudal peduncle sloped at $32-38^{\circ}(24)$, most frequently 33 $\left.35^{\circ} *\right)$, relative to vertebral column.
Coloration. Rhamdiopsis krugi is completely devoid of pigmentation. It has been determined to be a $\operatorname{DOPA}(+)$ albino, i.e., it is able to synthesize melanin in the presence of 1-DOPA(13,4-dihydroxyphenil-alanine) (Trajano \& de Pinna, 1996; Trajano, 2007). The body coloration in life is light rosy (Trajano, 1998; Figs. 12-13), becoming light grey or light yellow when preserved.

Karyotype. The karyotype of $R$. krugi, based on examination of two females, shows a modal diploid number of $2 n=56$, with 26 metacentric/submetacentric and 30 subtelocentric/ acrocentric chromosomes (Souza et al., 1994).

Etymology. The specific epithet krugi is given in honor of Luiz Krug, professional tourist guide based in the city of Lençóis, in the Chapada Diamantina area, who called our attention of the existence of this new catfish and helped to collect its type series, and for his efforts dedicated to its conservation.

Common names. Bagre cego (Souza et al., 1994; Trajano, 1998; Karmann et al., 2002); bagrinho (Trajano, 1998; Trajano \& Bichuette, 2006).

Distribution. Rhamdiopsis krugi occurs in the lake inside the Poço Encantado cave, and isolated pools inside the Lapa do Bode and Natal caves, which belong to the speleological province of Bambuí, northeastern Brazil, State of Bahia, in the Chapada Diamantina region (Fig. 14). The first two 


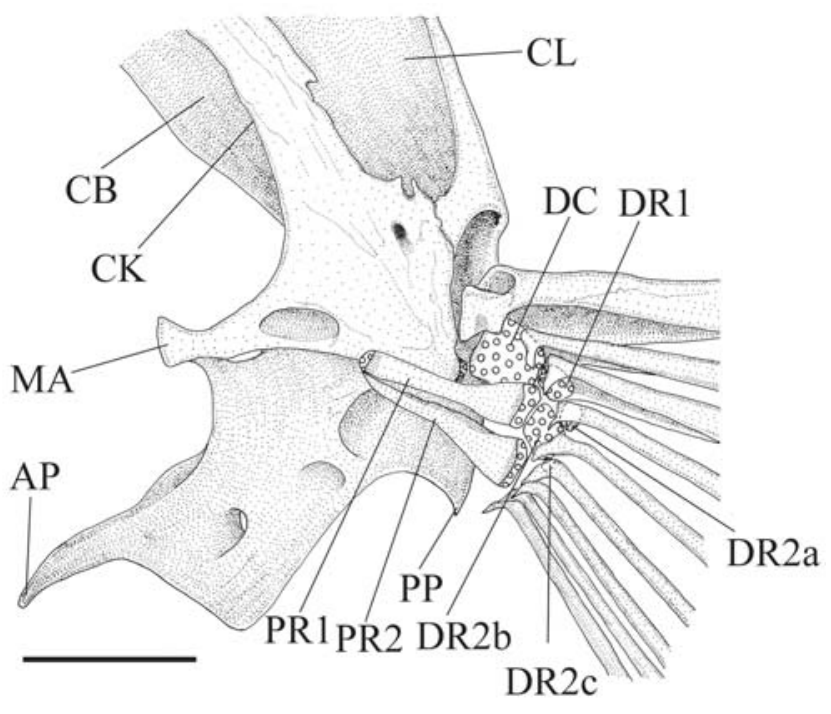

Fig. 9. Basal region of left pectoral fin and proximate portions of pectoral girdle of Rhamdiopsis krugi, LIRP 5928, $33.9 \mathrm{~mm}$ SL, paratype. Ventral view. AP) articular cleithral process; $\mathbf{C B}$ ) posterior complex bone of pectoral girdle (scapula, coracoid, and mesocoracoid fused); CK) coracoid keel; CL) cleithrum; DC) complex distal radial; DR1) distal radial 1; DR2a-c) pieces of distal radial 2; MA) mesocoracoid arch; PP) postcleithral process; and PR1-2) proximal radials 1 and 2 . Scale bar $=0.7 \mathrm{~mm}$.

localities are near to the left margin of the rio Una, an affluent of the right bank of the rio Paraguaçu, while the last locality is near to the right margin of the rio Una. In the published literature, this species has been recorded from five other localities, all in the upper rio Paraguaçu basin, Chapada Diamantina region: Poço Azul cave (12 46'56.9"'S $41^{\circ} 08^{\prime} 57.1^{\prime \prime} \mathrm{W}$ ), also called Poço Azul do Milu cave (see also Rubbioli, 1998), and Gruta Moreno cave (1248'32.7'"S $41^{\circ} 09^{\prime} 53.1$ "W), both near to the left margin of the rio Paraguaçu, in the Municipality of Nova Redenção (Trajano, 1997b; Bichuette, 2004; Trajano et al., 2005); Gruta Torrinha $\left(12^{\circ} 20^{\prime} 57.3^{\prime \prime S} 41^{\circ} 36^{\prime} 12.1^{\prime \prime} \mathrm{W}\right)$ and Lapa Doce caves $\left(12^{\circ} 20^{\prime} 02.2^{\prime \prime} \mathrm{S} 41^{\circ} 36^{\prime} 14.6^{\prime \prime} \mathrm{W}\right)$, both on left margin of the rio Santo Antônio, a tributary of left margin of the rio Paraguaçu, in the Municipality of Iraquara (Bichuette, 2004; Trajano et al., 2005); and Canoa Quebrada cave $\left(12^{\circ} 25^{\prime} 29.7^{\prime \prime} \mathrm{S}\right.$ $41^{\circ} 33^{\prime} 28.2^{\prime \prime} \mathrm{W}$ ), on left margin of the rio Santo Antônio, in the Municipality of Palmeiras (Trajano et al., 2005). Mendes (1998b) mentioned the occurrence of a blind and unpigmented fish in a cave in the Municipality of Iraquara, about $100 \mathrm{~km}$ northwest from the Poço Encantado cave, which probably corresponds to the Lapa Doce cave. In her article is shown a photograph of a troglobitic heptapterid similar to $R$. krugi, but no locality has been assigned to that specimen. Rhamdiopsis krugi is further reported to occur in a few other caves in Chapada Diamantina (Bichuette, pers. comm.). Because no specimen from these localities has been examined for this study, we refrain to identify them as $R$. krugi.

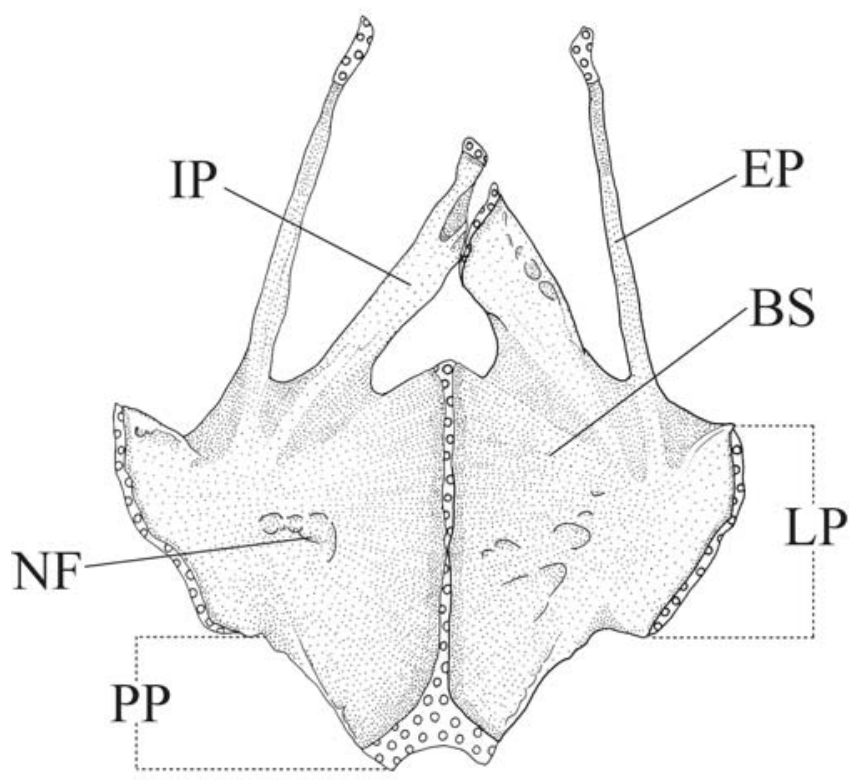

Fig. 10. Pelvic girdle of Rhamdiopsis krugi, LIRP 5928, $33.9 \mathrm{~mm}$ SL, paratype. Dorsal view. BS) basipterygium; EP) external anterior process (or anterolateral arm); IP) internal anterior process (or anteromedial arm); LP) lateral process; NF) neural foramen; and PP) posterior process. Scale bar $=1 \mathrm{~mm}$.

Habitat. Rhamdiopsis krugi inhabits the upper phreatic zone of a large karstic area (over $300 \mathrm{~km}^{2}$ ) including limestones and quartzites, which is connected to surface through caves. The catfishes are expected to occur in the aquifers between the caves (Mendes, 1995c; Trajano, 1997b, 2001a; Trajano \& Bockmann, 2000). It is known to live in lentic waters (Trajano \& Bockmann, 1999a, 2000; Trajano, 2001a) formed by the water table inside the caves, varying from large, partially illuminated lakes as in the Poço Encantado cave (lake with $110 \mathrm{~m} \mathrm{X} 50 \mathrm{~m}, 20-65 \mathrm{~m}$ deep; Fig. 15) to isolated pools as in the Lapa do Bode and Gruta Natal caves (Mendes, 1995a; Trajano, 1997b). It is probable that the lakes inside Poço Encantado, Lapa do Bode, and Gruta Natal are connected to each other via aquifers because their

Fig. 11 (next page). Caudal skeleton of Rhamdiopsis krugi, LIRP 5928. a) paratype $25.9 \mathrm{~mm} \mathrm{SL}$, showing hypural 5 distally fused to hypurals $3+4 ;$ b) paratype $33.9 \mathrm{~mm} \mathrm{SL}$, showing hypural 5 totally fused to hypurals $3+4$. EP) epural; HA+HAS) complex hypurapophysis composed of hypurapophysis and secondary hypurapophysis; HU3+HU4) complex dorsal plate formed by co-ossification of hypurals 3 and 4; HU3+HU4+HU5) complex dorsal plate formed by coossification of hypurals 3,4 , and 5; HU5) hypural 5; OC) opistural cartilage; $\mathbf{P H}+\mathbf{H U 1}+\mathbf{H U} 2)$ complex ventral plate formed by co-ossification of parhypural and hypurals 1 and 2; PU1+U1) complex centrum composed of preural centrum 1 and ural centrum 1; PU2) preural centrum 2; and UR) uroneural. Scale bars $=1 \mathrm{~mm}$. 


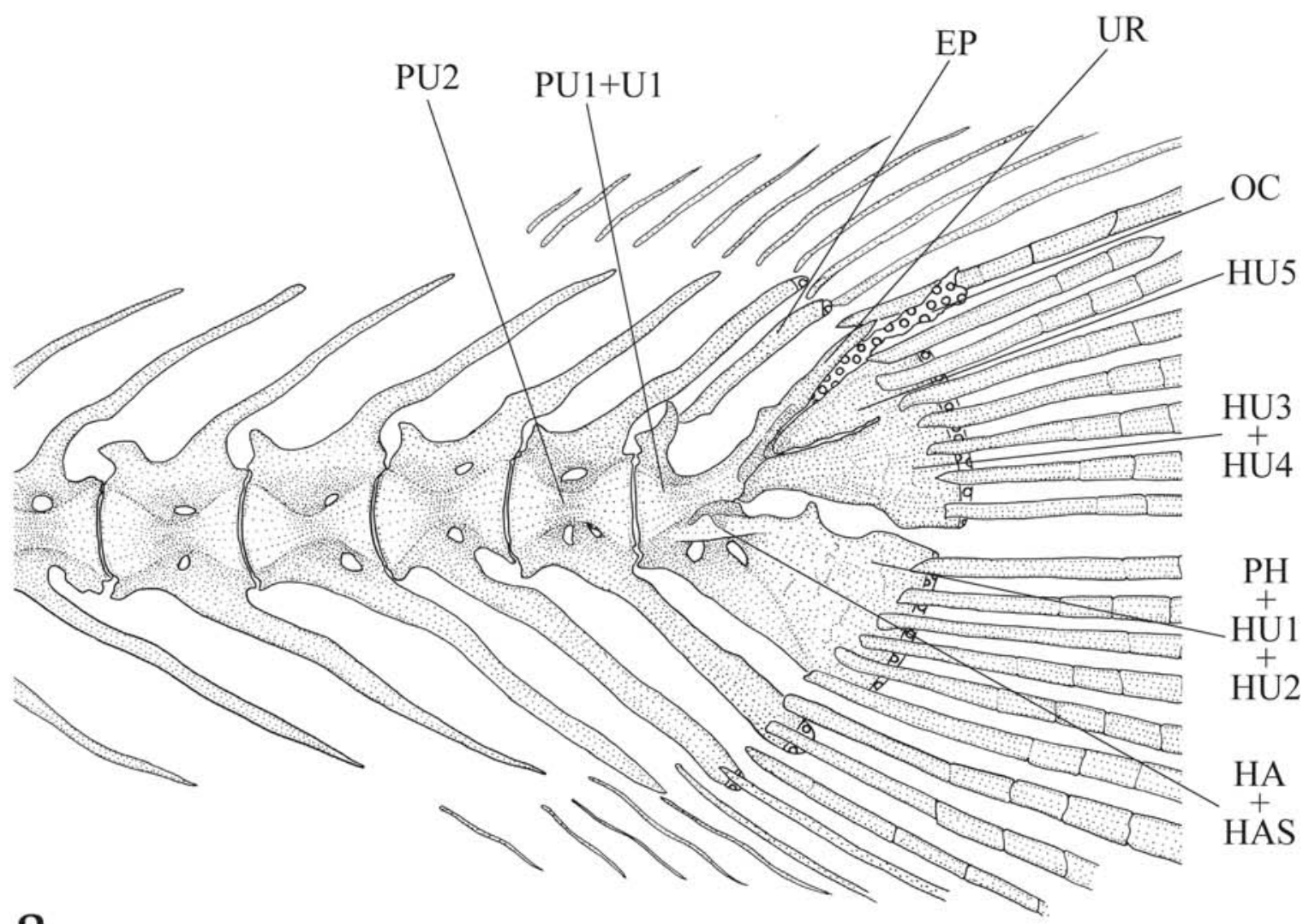

a

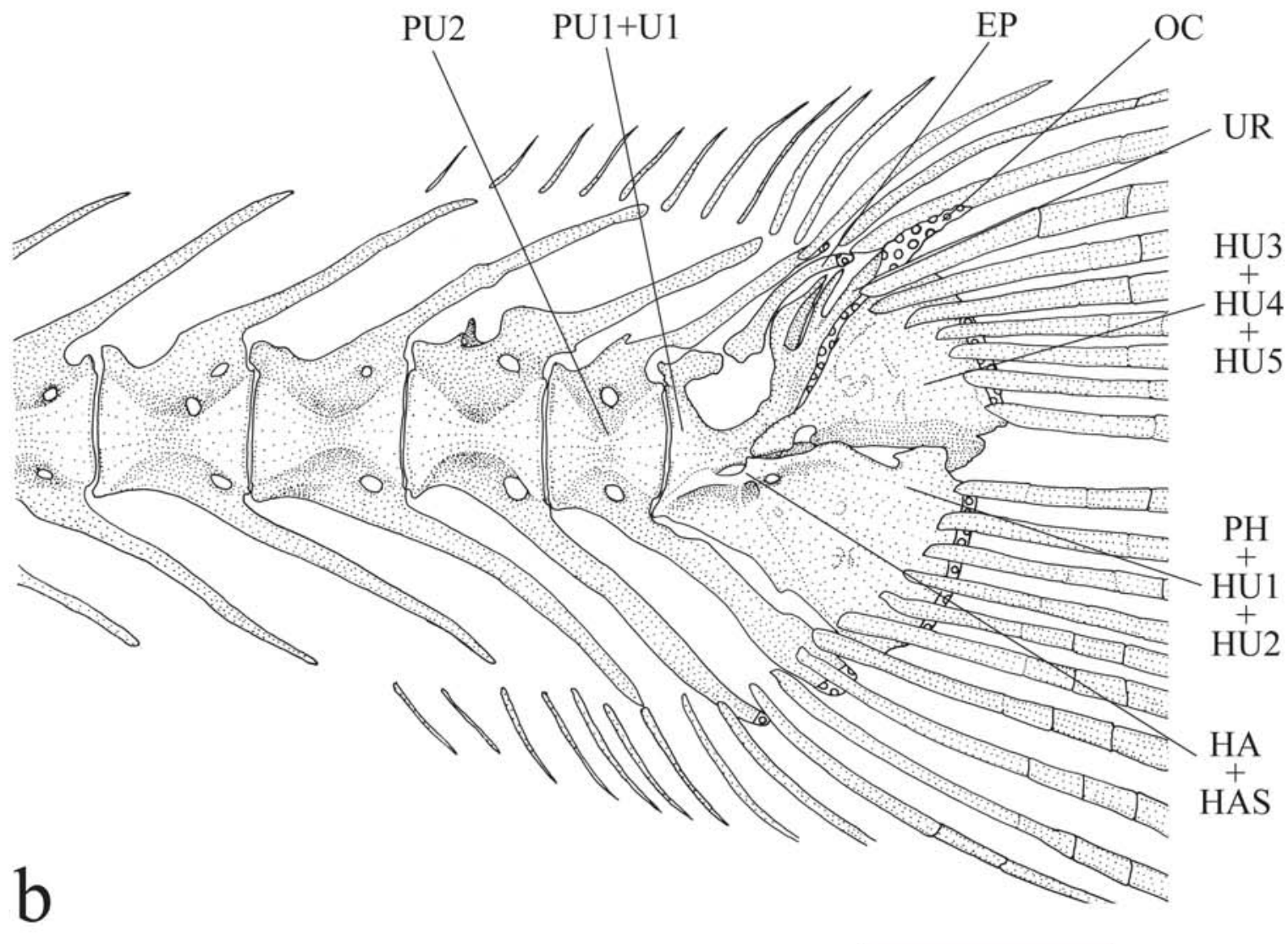


variations in water level follow those observed in the rio Una (Karmann et al., 2002). Whereas the Poço Encantado lake is located inside the main, large hall (about $40 \mathrm{~m}$ ) of the cave, Lapa do Bode is a horizontal, predominantly dry cave, with numerous labyrinthic passages 2.0 wide and 2.5 high, in average. In the Lapa do Bode cave, R. krugi is found in three isolated pools; during the dry season the first and second pools were totally dried (Mendes, 1995c). The lake in the Poço Encantado cave has pristine waters (Mendes, 1995b). Rhamdiopsis krugi lives under seasonal climates, in the Brazilian Semiarid Region, subject to a pronounced and well-marked dry period (Trajano, 1997b, 2001a). In the lake of the Poço Encantado cave, the water temperature and $\mathrm{pH}$ are mostly constant along the year, about $25^{\circ} \mathrm{C}$ and $7-8$, respectively, the water conductivity is high $\left(48.5 \mathrm{~S} \mathrm{~cm}^{-1}\right)$, probably due to limestone composition of the cave, the luminosity is between zero in the darkest area and 40 lux in the clearest, and the water level changes through the year is approximately $1 \mathrm{~m}$, probably associated to the rainy and dry seasons (Mendes, 1995b, 1995c). Greater details on the Poço Encantado cave are found in Karmann et al. (2002).

Behavior. Rhamdiopsis krugi is mainly solitary (Mendes, 1995c; Trajano \& Bockmann, 1998, 1999b), as much as all Brazilian cave catfishes (Trajano \& Bockmann, 1999a). In the lake of the Poço Encantado cave, R. krugi was observed swimming until about $35 \mathrm{~m}$ in depth, but it usually aggregates between the surface and 10m (Mendes, 1995a, 1995c, 1998a; Trajano, 1997b, 2001a; Trajano \& Bockmann, 2000). It is said to have preference for substrate, concentranting in the rocky walls (Mendes, 1995c, 1997a; Trajano, 1997c; Fig. 12). Rhamdiopsis krugi has reduced cryptobiotic habits and increased midwater activity, exploring the water column and surface (Trajano, 1993, 2001a; Mendes, 1995c; Trajano \& Bockmann, 2000), which may represent juvenile behavioral traits retained by the adults (Trajano \& Bockmann, 1999a). Midwater activity of $R$. krugi probably enhances the chance of finding food in its poor habitats. This fish does not show generalized phobic reactions, being not photophobic and reacting to most physical stimuli, as those from water movements and sudden illumination; instead, it performs pronounced exploratory behavior when stimulated (Trajano, 1993, 1996; Mendes, 1995c; Trajano \& Menna-Barreto, 1995; Trajano \& Gerhard, 1997; Trajano \& Bockmann, 1999a). According to Trajano \& Bockmann (1999a), R. krugi does not show strong phobic reactions to stimuli possibly due to absence of important predation rates. This species also presents less intense, simplified agonistic interactions (Trajano, 1993, 1996; Mendes, 1995a, 1995b, 1995c). Specimens kept in aquaria showed mainly avoidance behavior when foraging during the night phase (Trajano \& Bockmann, 1999a). The low frequency of aggressive interactions may be a direct consequence of the reduction of cryptobiotic habits (Trajano \& Bockmann, 1999a). Mendes (1995c) mentioned that, in the habitat, no circadian activity has been detected for R. krugi. A similar conclusion was reached by Trajano \&
Menna-Barreto (1995) under laboratorial conditions. The individual variability observed in the free-running circadian rhythmicity of $R$. krugi may be attributed to the light-dark cycles which are nowadays acting over part of the studied populations (Trajano \& Menna-Barreto, 1995; Volpato \& Trajano, 2006). The average swimming speed of this catfish is approximately $0.03 \mathrm{~m} / \mathrm{s}$ when in normal activity, and $0.15 \mathrm{~m} / \mathrm{s}$ when stressed (Mendes, 1995c). According to Mendes (1995b, 1995c) the feeding tactic of $R$. krugi is substrate speculation while Trajano (1997a, 2001a) mentioned chemically-oriented predation of bottom animals, grubbing, and surface picking. Cannibalism was not observed for this species (Trajano \& Bockmann, 2000). Occupation of the bottom and midwater, non-cryptobiotic and non-photophobic behavior, reduced circadian rhythms were considered autapomorphies of $R$. krugi (Trajano \& Bockmann, 1999a).

Ecology. According to Mendes (1995a, 1995b), R. krugi feeds directly on bat guano. However, Trajano (2001a), based on field observations and examination of gut contents, mentioned that $R$. krugi is strictly carnivorous, preying on invertebrates found near or on the bat guano. All the specimens of $R$. krugi collected by chance had food in the stomachs (Trajano, 1997a). A frequency of occurrence of allochthonous (terrestrial) food items greater than $20 \%$ was reported to $R$. $k r u g i$, with the population from the Poço Encantado cave having a higher proportion of terrestrial prey than that from the Lapa do Bode cave (Trajano, 1997a). The stomach content of $R$. krugi is mainly composed of larvae of Diptera and microcrustaceans which allows characterize it as carnivorous (Mendes, 1995b, 1995c). Crustaceans represent $10.7 \%$ of the diet of the population of $R$. krugi from the Poço Encantado cave and $57.1 \%$ of the diet of the population of this species from the Lapa do Bode cave (Trajano, 1997a). These distinctions among diets may be due to differences in prey availability rather than feeding preferences (Trajano, 1997a). Such generalist, opportunistic diet is expected for animals living in a food-poor cave environment (Trajano, 1997a).

Although $R$. krugi lives in areas with a highly seasonal climate, its habitats are not subject to noticeable floods, with the species having a reproductive peak at end of the rainy period (Trajano, 1997a, 2001a). The proportion of mature individuals (with well developed gonads) of $R$. krugi between March and September was 17.7\% (Mendes, 1995c; Trajano, 1997a), indicating infrequent reproduction, and all mature females were found at end of the rainy season in March. The low proportion of ripe fish indicates that not all individuals of $R$. krugi reproduce every year which is expected in view of the food scarcity prevailing in the subterranean habitat, (Trajano, 2001a).

The population density of $R$. krugi is considered low (Mendes, 1995c, 1998; Trajano, 1997a, 1998, 2001a, 2003; Trajano \& Bockmann, 2000; Trajano et al., 2002), i.e., $<0.1$ individuals $\mathrm{m}^{-2}$ (Trajano, 2001a), evaluated to be between 0.03-0.05 ind./ $\mathrm{m}^{-2}$ through the year in the Poço Encantado cave. However, Trajano (2001a) noticed that the population density of $R$. krugi was estimated by visual censuses in a selected small area and, 


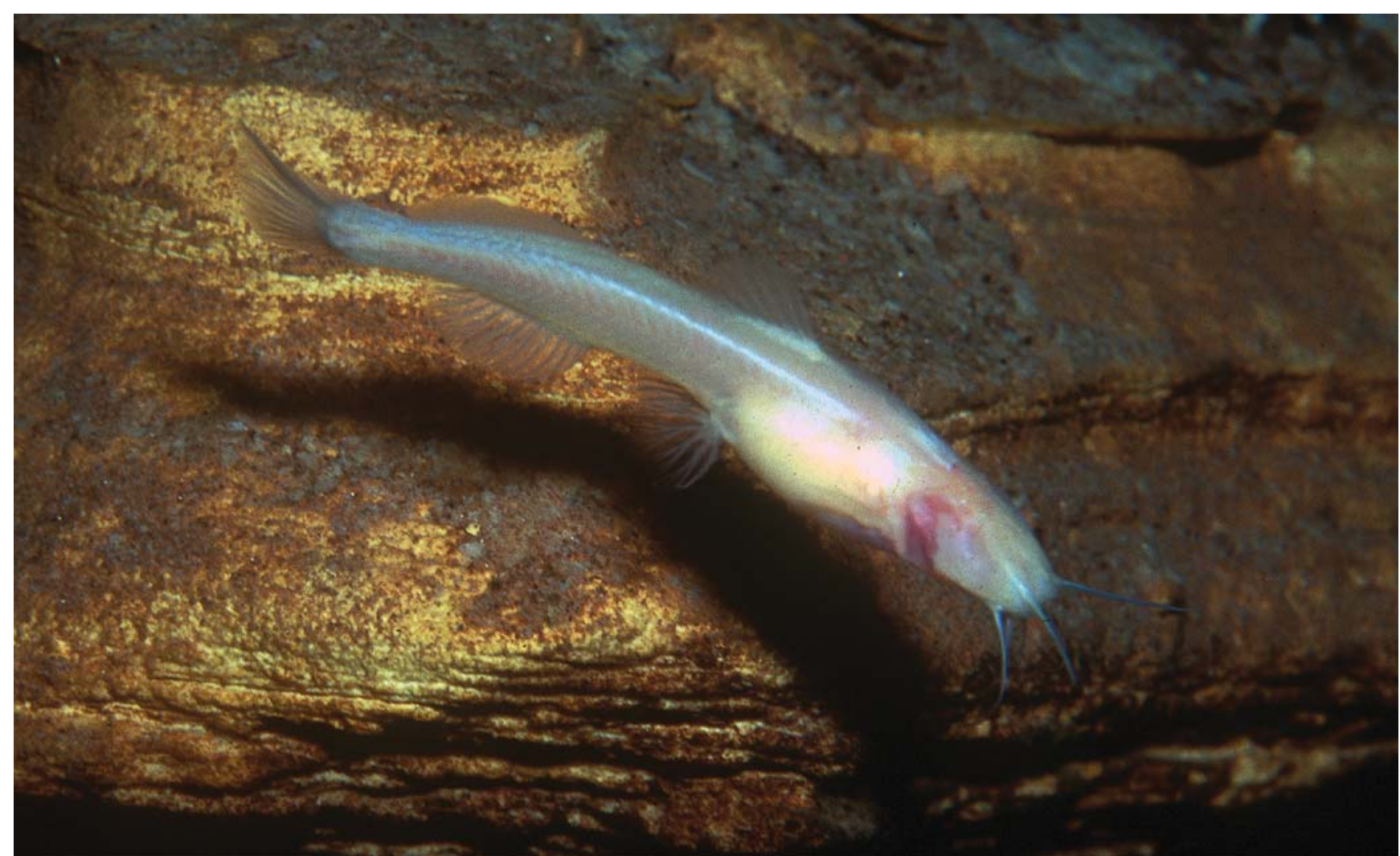

Fig. 12. Rhamdiopsis krugi, ca. $30.0 \mathrm{~mm} \mathrm{SL}$, adult, live specimen photographed in the nature in August, 1991, not collected; Poço Encantado cave, $c a .7 \mathrm{~km}$ from left margin of the rio Una, Municipality of Itaetê, State of Bahia, Brazil.

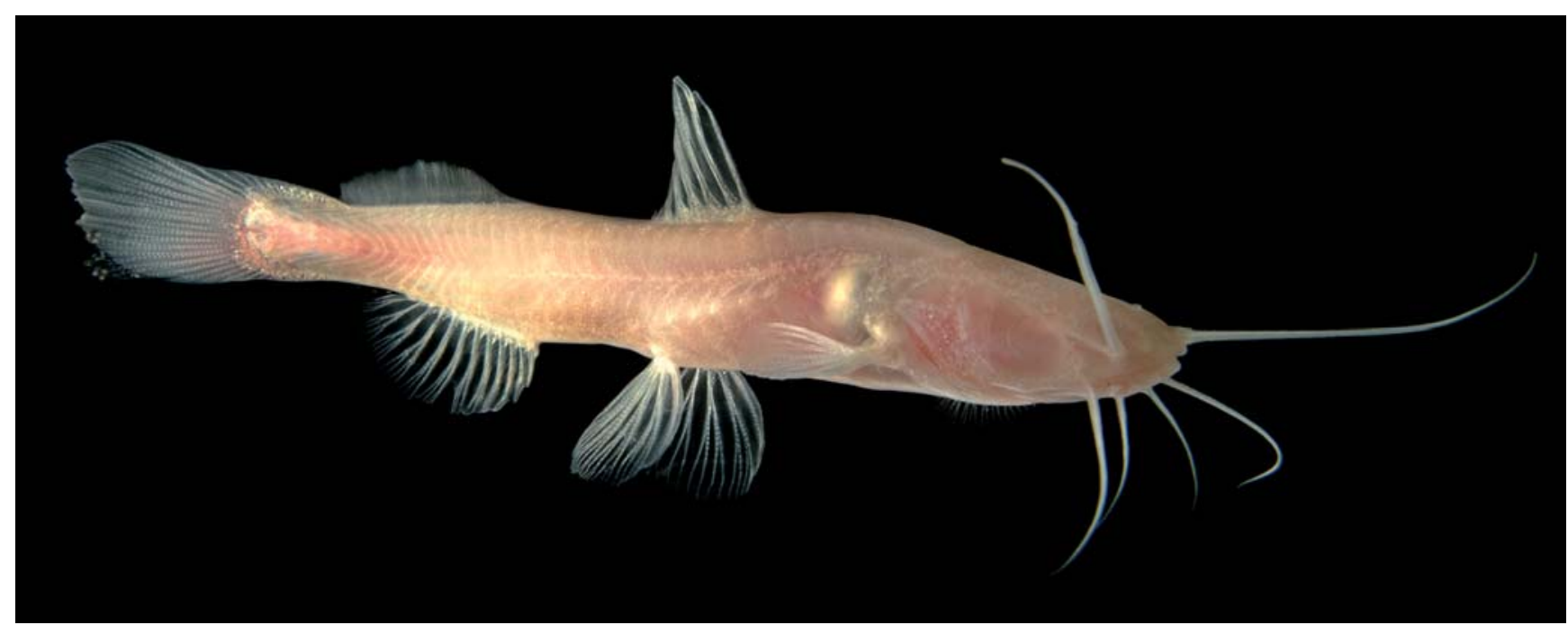

Fig. 13. Rhamdiopsis krugi, $32.5 \mathrm{~mm}$ SL, adult, live specimen photographed in aquarium on July $16^{\text {th }}$, 2008, unpreserved; Poço Encantado cave, left margin of the rio Una, Municipality of Itaetê, State of Bahia, Brazil. Courtesy of Adriano Gambarini.

therefore, more subject to errors due to spatial variation in fish density. Moreover, the real population size of $R$. krugi is hard to evaluate because part of it probably lives in a widely inaccessible portion of the phreatic habitat (Trajano, 2001a).

Extensive fieldwork showed that fish predators of $R$. krugi are actually absent or, if they do exist, these are so rare that their impact on the resident fish population is negligible (Trajano \& Bockmann, 2000; Trajano, 2001a). There is a general notion that, as a consequence of food scarcity, subterranean food pyramids would not support more than one level of predators (Mohr \& Poulson, 1966). Therefore, hypogean fishes, which are usually predaceous, would not generally be subject to important predation pressures, and some of their specializations, such as absence of generalized phobic reactions, reduction of cryptobiotic habits, and increased midwater activity, may be interpreted in this context (Trajano, 2001a). 


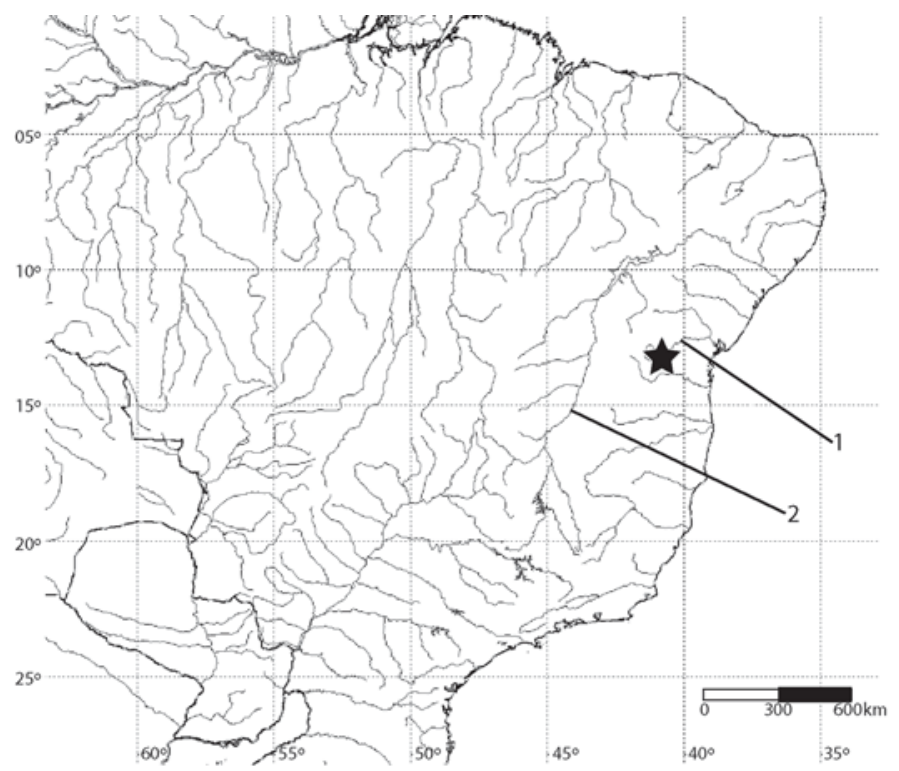

a
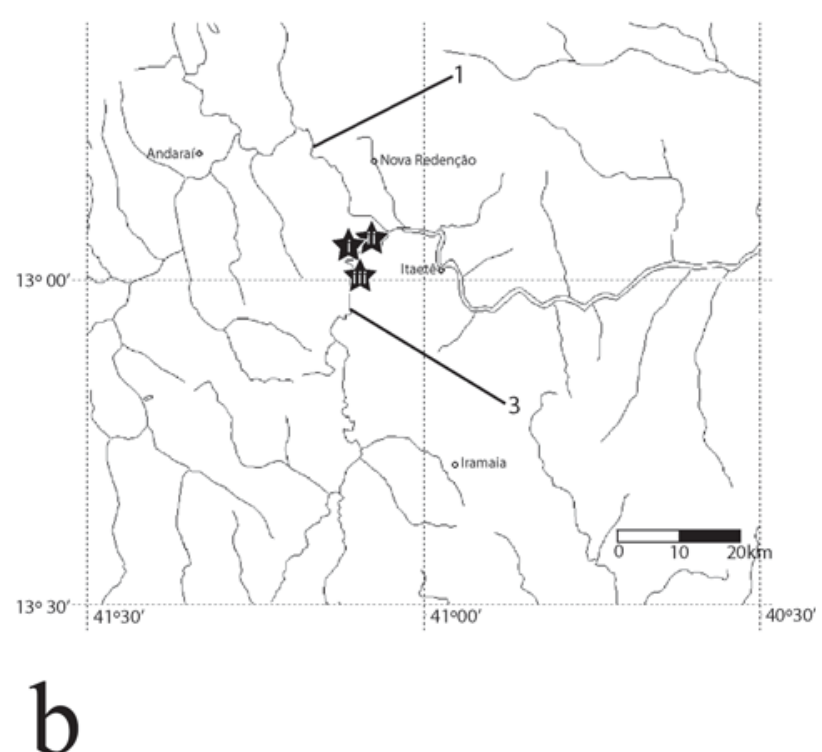

Fig. 14. Geographic distribution of Rhamdiopsis krugi. a) Eastern Brazil; b) detail of the upper rio Paraguaçu. Legends: 1) rio Paraguaçu; 2) rio São Francisco; 3 ) rio Una; i) Poço Encantado; ii) Lapa do Bode; and iii) Gruta Natal. Symbol (star) in map a represents the three localities.

Conservation notes. Given the relatively low population density of $R$. krugi in the lake of the Poço Encantado cave, swimming and diving in that place were prohibited by municipality law (Trajano, 1997b; Trajano \& Bichuette, 2006). Despite R. krugi being known to occur in a considerable wide area, inhabiting at least two other caves of the region, the species is endangered due to several factors. The habitats where $R$. krugi live have low water circulation, favoring the accumulation of garbage and debris (Trajano \& Bichuette, 2006). The Chapada Diamantina is situated in the semiarid of northeastern Brazil, the poorest region of the country, which is chronically devastated by the problem of drought. The disordered exploration of the subterranean waters in that region - there are about 2000 artesian wells - may lead to the progressive lowering of the water table level (M. E. Bichuette \& E. Trajano, pers. comm.). Furthermore, conservation priorities should be directed to $R$. krugi because pollution of the waters of the aquifer that feeds the habitats where it lives has already been documented through geochemical studies (Trajano \& Bichuette, 2005b, pers. comm.).

\section{Phylogenetics relationships of Rhamdiopsis krugi}

Rhamdiopsis krugi was assigned to the family Heptapteridae and treated as an unresolved branch of the Nemuroglanis sub-clade (Trajano \& Bockmann, 1998, 1999a; Trajano et al., 2004, 2005), but no reason has been presented to support these conclusions. Rhamdiopsis krugi is indeed a member of the family Heptapteridae as it shares all of its synapomorphies (Lundberg \& McDade, 1986; Lundberg et al., 1991; Bockmann, 1998). Within heptapterids, the Nemuroglanis sub-clade is a well-corroborated group (Ferraris, 1988; Bockmann, 1994). This clade comprises Acentronichthys Eigenmann \& Eigenmann, Cetopsorhamdia Eigenmann \&
Fisher, Chasmocranus Eigenmann, Heptapterus Bleeker, Horiomyzon Stewart, Imparfinis, Mastiglanis Bockmann, Nannoglanis Boulenger, Nannorhamdia Regan, Nemuroglanis Eigenmann \& Eigenmann (including Imparales Schultz and Medemichthys Dahl - see Bockmann \& Ferraris, 2005), Pariolius Cope, Phenacorhamdia Dahl, Phreatobius, Rhamdioglanis Ihering, Rhamdiopsis, and Taunayia Miranda-Ribeiro. It is supported by the following synapomorphies (Ferraris, 1988; Bockmann, 1994): 1) laminar portion of complex centrum transverse process, posterior to branched segment, is triangular and extends nearly to the lateral tip of fifth vertebral transverse process; 2) first dorsal-fin basal pterygiophore is inserted behind Weberian complex, usually above vertebrae 7 to $10 ; 3$ )

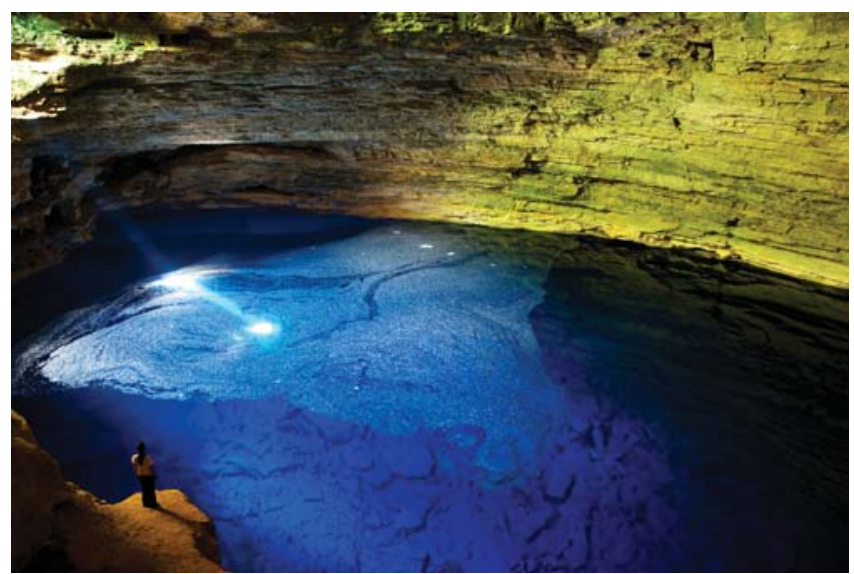

Fig. 15. View of the type-locality of Rhamdiopsis krugi, Poço Encantado cave (12 $566^{\prime} 37^{\prime}$ 'S $\left.41^{\circ} 06^{\prime} 05^{\prime \prime} \mathrm{W}\right)$, Municipality of Itaetê, Bahia, northeastern Brazil, taken in 2008. Courtesy of Adriano Gambarini. 
"dorsal-fin spine" is thin and flexible; 4) dorsal-fin lock (= first dorsal spine or spinelet) absent; 5) pectoral-fin "spine" is thin and flexible for its distal half, rather than pungent; 6) mesocoracoid arch modified into a wide band; 7) two posterior proximal radials of pectoral fin are enlarged and flattened; 8) pectoral girdle delicate, with a short mesial contact line comprising only three weakly joined scapulo-coracoid dentations; 9) pointed process projected posteroventrally from the coracoid keel absent; 10) posterior chambers of swimbladder atrophied, conforming a bilobed, transversely aligned structure; 11) nasal bone long and weakly ossified; 12) ridges of neural arch of the fourth vertebra absent (which is more properly defined as neural arch of the fourth vertebra approximately straight, not covering the neural arch of the fifth vertebra and not giving rise to two divergent ridges that reach the anterior limbs of the transverse process of the fourth vertebra); 13) presence of a distinct deep medial notch which divides the posterior limb of the fourth transverse process into two divergent, approximately symmetrical, long arms; 14) tips of the parapophyses of anterior free vertebrae distally expanded and ventrally concave; 15) hemal and neural spines of the caudal vertebrae oriented at about $35^{\circ}$ to the vertebral column axis; and 16) hemal and neural spines of the last free precaudal vertebrae robust.

As it may be verified in the description of R. krugi, this species possess most of these synapomorphies of the Nemuroglanis sub-clade. However, some of them cannot be promptly identified in $R$. krugi. Although the posterior portion of the posterior branch of transverse process of vertebra 4 is triangular, its posterolateral corner does not extend to the lateral tip of fifth vertebral transverse process (Ferraris, 1988), reaching approximately to midlength of transverse process of vertebra 5 (Fig. 7). The swimbladder of $R$. krugi is comparatively larger than that of other members of the Nemuroglanis sub-clade (nonetheless it keeps the apomorphic bilobed shape), so that it cannot be properly classified as atrophied (Fig. 7). The posterior limb of the fourth transverse process of $R$. krugi is undivided, bearing a spatulated shape, therefore lacking the deep medial notch, which separates it into two divergent arms (Fig. 7). Despite these three exceptions, R. krugi is an undisputable member of the Nemuroglanis sub-clade, representing the single described troglobitic member of this group [Taunayia sp. from Campo Formoso, State of Bahia, Brazil (Trajano \& Bockmann, 1999a, 2000), and a species of Rhamdiopsis with weakly developed troglomorphisms, from Cordisburgo, State of Minas Gerais (Trajano \& Bichuette, 2005b; Trajano, 2007) remain to be described].

Despite having its ecology and behavior extensively researched during the last 17 years (e.g., Trajano, 1993, Mendes, 1995a, 1995c), R. krugi remained scientifically undescribed until now. Notwithstanding it has been discovered less than two decades ago, R. krugi accumulated a large number of names, some informal, and was assigned to four heptapterid genera, one of them undescribed. When first appeared the literature, it was allocated in the genus Rhamdella (e.g., Trajano, 1993; Trajano \& Sánchez, 1994). Such a generic allocation is due to the fact that $R$. krugi was thought to be similar to species of Imparfinis, which were, in that epoch, traditionally assigned to a broadly inclusive Rhamdella. This genus has been recently constrained to five species from southern and central South America and it has a basal position inside the family Heptapteridae (Bockmann \& Miquelarena, 2008). The blind catfish from Chapada Diamantina definitively cannot be assigned to Rhamdella.

The second provisory position of $R$. krugi was in the genus Imparfinis (e.g., Trajano \& Menna-Barreto, 1995; Trajano, 1996, 1997a). However, the resemblance between $R$. krugi and species of that genus are plesiomorphies only. In addition, Bockmann \& Ferraris (2005) diagnosed the group constituted by Horiomyzon, Imparfinis, Mastiglanis, and Nemuroglanis on the basis of the possession of borders of contact between the frontals, sphenotics, pterotics, and supraoccipital mostly smooth. Instead, these bones have conspicuous dentate sutures in R. krugi (Fig. 4a).

The third hypothesis postulated that $R$. krugi would be dealt in a new genus (e.g., Trajano, 1997b, 1998, 2001a, 2001b, 2003; Trajano \& Bockmann, 1999a; Trajano \& Bichuette, 2006; Volpato \& Trajano, 2006). Such a generic assignment was broadly founded on the aberrant autapomorphies (including troglomorphisms) of R. krugi, which are indeed not informative for accessing its kinship. Inasmuch as the phylogenetic relationships among heptapterids are being progressively clarified (Bockmann, 1998; Bockmann \& Ferraris, 2005; Bockmann \& Miquelarena, 2008), the proposition of a new genus for $R$. krugi has been demonstrated to be unnecessary.

At last, the new blind heptapterine from Chapada Diamantina was assigned to the genus Rhamdiopsis by Trajano (2007), based on information provided by one of us (FAB). This generic allocation is justified by a new diagnosis for Rhamdiopsis, which was herein modified to include $R$. krugi. Undescribed species of Rhamdiopsis have been recently cited in the literature (Bizerril, 1999; Santos, 2005; Santos \& Caramaschi, 2007), including one troglobitic (Trajano, 2001b, 2007; Trajano \& Bichuette, 2005b). All these mentions were based on our ongoing revisionary work on this genus (Bockmann \& Castro, in prep.). Due to the preliminary nature of these taxonomic data, we prefer to focus our comparisons on the valid species only, leaving the undescribed species apart from this study. Thus, Rhamdiopsis, as defined below, includes $R$. krugi, from the caves in northeastern Brazil drained by the upper rio Paraguaçu basin, R. microcephala (Lütken), from the upper rio São Francisco, and $R$. moreirai Haseman, from the upper reaches of the rio Iguaçu (rio Paraná basin) and the rio Ribeira de Iguape (Bockmann \& Guazzelli, 2003). These three species share four putative apomorphies:

1) Posterior nare with a large gap devoid of dermal flap (Fig. 3b). The posterior nare of the majority of the members of the family Heptapteridae, as well in the most catfishes, is completely surrounded by a dermal flap except for a very small extension around its posterior border. In contrast, the posterior nare of $R$. microcephala, $R$. moreirai, and $R$. krugi has a large portion, almost corresponding to its entire posterior half, devoid of dermal flap. 
2) Preoperculomandibular and postotic laterosensory canals separated from each other (Fig. 3b). In all Rhamdiopsis species the preoperculomandibular and postotic laterosensory canals are separated from each other, each one bearing its own pore (pm11 and pol pores, respectively). In the primitive condition, which is exhibited by nearly all other heptapterids, the preoperculomandibular and postotic laterosensory canals are united to each other, bearing a single complex pore (po1+pm11). Most specimens of R. krugi exhibit this condition, with its holotype that has fused pores on one side of the head being the single exception (Fig. 3a-b). Among heptapterids, this plesiomorphy has been illustrated for Nemuroglanis pauciradiatus Ferraris (Bockmann \& Ferraris, 2005; Bockmann \& Castro, 2008) and Rhamdella cainguae Bockmann \& Miquelarena (Bockmann \& Miquelarena, 2008). The derived condition occurs homoplastically in Gladioglanis Ferraris \& Mago-Leccia and Nemuroglanis lanceolatus Eigenmann \& Eigenmann (Bockmann \& Ferraris, 2005), and Heptapterus multiradiatus Ihering and $H$. sympterygium Buckup (Buckup, 1988).

3) Caudal fin emarginate. The caudal-fin lobes of R. krugi, $R$. microcephala, and $R$. moreirai are distinctly short, attenuate, delineating an almost truncate shape to caudal fin (Figs. 1, 1213). Similar caudal fin shape is also seen in Chasmocranus longior Eigenmann, Nannoglanis fasciatus Boulenger, Pariolius armillatus Cope, and Taunayia bifasciata (Eigenmann \& Norris). Although all are members of the Nemuroglanis sub-clade (Ferraris, 1988; Bockmann, 1994), these are distantly related to Rhamdiopsis (Bockmann, 1998). Therefore, these conditions are interpreted as homoplasies.

4) Lateral line incomplete, with its terminus reaching to posterior half of adipose fin. The lateral line of the trunk of $R$. microcephala and $R$. moreirai is long but it is formed by patches of pores, gradually more spaced posteriorly, ending at about below the posterior half of adipose fin. A similar condition is present in Acentronichthys (Bockmann, 1998; Bockmann \& Ferraris, 2005). The lateral line of R. krugi is much shorter than that of its congeners (Trajano \& Bockmann, 2000), extending to below dorsal-fin base (Fig. 3a). The lateral line unfragmented, extending continuously to the middle of the caudal-fin lobes is widespread among the majority of catfishes (Lundberg, 1992), including most of heptapterids.

Two apomorphic states indicate that $R$. krugi and $R$. moreirai are sister species:

1) Epiphyseal branches of supraorbital laterosensory canals not fused to each other, each one bearing its own pore, the s6 pore (Figs. 3b, 4a). The epiphyseal branches of the supraorbital laterosensory canals of $R$. microcephala are fused to each other, bearing a single symphyseal pore $(s 6+s 6)$, which is the presumable plesiomorphic state (Bockmann \& Ferraris, 2005). Among heptapterids, this condition has been illustrated for Nemuroglanis pauciradiatus (Bockmann \& Ferraris, 2005) and Rhamdia quelen (Silfvergrip, 1996). The derived state of this character occurs homoplastically in Brachyglanis Eigenmann, Brachyrhamdia Myers, Gladioglanis, Heptapterus sympterygium, Leptorhamdia Eigenmann, Myoglanis Eigenmann, and Nemuroglanis lanceolatus (Bockmann \& Ferraris, 2005).
2) Ventral caudal plate with 6-7 rays. The ventral caudal plate of the most of siluriforms (composed of one parhypural plus hypurals 1 and 2), including most of heptapterids, supports plesiomorphically 8-9 rays (Bockmann \& Ferraris, 2005). Rhamdiopsis moreirai presents 7 rays articulated to ventral caudal plate while $R$. krugi has typically 6 (17), less commonly 7 rays (7). Rhamdiopsis microcephala has the plesiomorphic state, with 8-9 rays on ventral caudal plate. Among heptapterids, similar conditions to that also found in R. krugi and R. moreirai are also present in Acentronichthys, Horiomyzon, Myoglanis, Nemuroglanis mariai (Schultz), and Rhamdioglanis (Bockmann \& Ferraris, 2005). Further advanced states are found in Heptapterus, Nemuroglanis lanceolatus, N. pauciradiatus, Pariolius, and Phreatobius (Bockmann \& Ferraris, 2005). All those derived conditions are interpreted as homoplasies in relation to the states shown by R. krugi and R. moreirai (Bockmann \& Miquelarena, 2008).

On the other hand, two other derived character states point to an alternative sister-group relationship of $R$. moreirai with $R$. microcephala:

1) Dorsal fin small. This character state is expressed by the short dorsal-fin base, with $R$. microcephala having 8.9$11.4 \% \mathrm{SL}($ mean $=10.5 \%, \mathrm{SD}=1.1, \mathrm{~N}=5)$ and $R$. moreirai having $6.5-9.6 \% \mathrm{SL},($ mean $=8.2 \%, \mathrm{SD}=0.9, \mathrm{~N}=12)$ and short length of third dorsal-fin ray, with $R$. microcephala having $13.8-16.4 \% \mathrm{SL}($ mean $=15.2 \%, \mathrm{SD}=1.1, \mathrm{~N}=5)$, and $R$. moreirai having $12.3-14.3 \% \mathrm{SL}($ mean $=13.3 \%, \mathrm{SD}=0.6, \mathrm{~N}=12)$. Rhamdiopsis krugi has a distinctly larger dorsal fin, with overall size similar to those found among basal heptapterids (Bockmann \& Miquelarena, 2008), with dorsal-fin base 11.2$14.1 \% \mathrm{SL}$ (mean $=12.2 \%, \mathrm{SD}=0.8, \mathrm{~N}=20)$ and length of third dorsal-fin ray $14.4-18.7 \% \mathrm{SL}$ (mean $=16.4 \%, \mathrm{SD}=1.2, \mathrm{~N}=19$ ).

2) Anal fin long, with 20 or more rays. Rhamdiopsis microcephala and $R$. moreirai share a long anal-fin base, bearing 20-21 and 23-25 rays, respectively. Rhamdiopsis krugi has a comparative shorter anal-fin base, which is typically supported by $14-15$, less commonly 13 or 16-17 rays (Table 1), a range within the hypothesized plesiomorphic count for analfin rays (Bockmann \& Miquelarena, 2008).

Therefore, at this moment, it is not possible to establish the affinities of $R$. krugi with its congeners because they share ambiguous derived characters. Rhamdiopsis krugi is diagnosed by a high number of autapomorphies, 24 in the total, which are described and discussed in greater detail below:

1) Ethmoidean cartilage discontinuous. Primitively among heptapterids, the ethmoidean cartilage is a continuous sheet between each lateral ethmoid, extending itself between the anterior edge of the lateral ethmoid and the posterior portion of mesethmoid, bordering the lateral margin of the lateral ethmoid to the condyle for the autopalatine (Bockmann, 1998). Distinctly, most c\&s specimens (3 of 4) of Rhamdiopsis krugi have the ethmoidean cartilage fragmented in the median part between the mesethmoid and the lateral ethmoid (Fig. 4). Within the heptapterids, this apomorphic condition was only known for Phreatobius (Bockmann, 1998). 
2) Eyes completely absent and correlated optic foramen atrophied (Figs. 1-4, 12-13). All alcoholic-preserved and cleared and stained specimens of $R$. krugi show no vestige of eyes and/or of any related nerve (Mendes, 1995d; Figs. 1-2), even in the smallest specimen $(25.1 \mathrm{~mm} \mathrm{SL})$. For this reason, it is not improbable that the eyes of $R$. krugi are absent since the beginning of its development, representing a case of early truncating in ontogeny. The eyes of the other species of Rhamdiopsis are, even though small, regularly present, with $12.9-14.0 \%$ in $\mathrm{HL}$ ( mean $=13.8 \%, \mathrm{SD}=0.6, \mathrm{~N}=5)$ in $R$. microcephala and $10.2-14.7 \%$ in $\mathrm{HL}$ ( mean $=12.0 \%, \mathrm{SD}=1.4$, $\mathrm{N}=12$ ) in R. moreirai. Among the troglomorphic heptapterids, invariably complete anophthalmy, like that of $R$. krugi, also occurs in Phreatobius dracunculus, $P$. sanguijuela, and the undescribed Taunayia sp. from Campo Formoso, State of Bahia, Brazil (Fernandez et al., 2007; Shibatta et al., 2007; Trajano \& Bockmann, 2000). The typical optic foramen in heptapterids, which is framed anterodorsally and anteroposteriorly by the orbitosphenoid, posterodorsally by the pterosphenoid, and posteroventrally by the parasphenoid (Bockmann \& Miquelarena, 2008), is a narrow vertical fissure bordered anteriorly by the orbitosphenoid and posteriorly by the parasphenoid in $R$. krugi (Fig. 4b). The optic foramen of $R$. microcephala and R. moreirai has an intermediate state, being a relatively small, ovoid opening between orbitosphenoid, pterosphenoid, and parasphenoid.

3) Supraorbital and infraorbital sensory canals not connected to each other anteriorly. In the majority of teleosteans, including siluriforms, the supraorbital and infraorbital sensory canals do not fuse anteriorly (Arratia, 1987; Arratia \& Huaquín, 1995), each one opening through its own pore (s2 and i2, respectively). Arratia (1987) correctly noticed that in both Heptapterus and Pimelodella the supraorbital and infraorbital canals apomorphically merge at their anterior extremities in a common branch which opens into a single shared pore, the $\mathrm{s} 2+\mathrm{i} 2$. Among the Heptapteridae, this state has been illustrated for Gladioglanis machadoi Ferraris \& Mago-Leccia (Ferraris \& Mago-Leccia, 1989), Heptapterus mustelinus (Valenciennes) (Arratia, 1987), $H$. sympterygium (Buckup, 1988), Phenacorhamdia tenuis Mees (Mees, 1986), Rhamdella cainguae (Bockmann \& Miquelarena, 2008), Rhamdia laukidi Bleeker (Silfvergrip, 1996), and R. muelleri (Günther) (Silfvergrip, 1996), and it been diagnosed as an almost unreversed synapomorphy for the whole family (Bockmann, 1998). Approximately $67 \%$ of examined specimens of $R$. krugi do not have the apomorphic condition, bearing, at least on one side of head, independent s2 and i2 branches and pores (Figs. 3b, 4a). This state of $R$. krugi is interpreted as a reversal which, among heptapterids, occurs homoplastically only in Horiomyzon (Bockmann, 1998).

4) Presence of s7 branch and pore of the supraorbital laterosensory canal. The s7 branch and pore are present in the most basal members of the Heptapteridae. Among heptapterids, this state has been illustrated for Pimelodella sp. (Bockmann \& Miquelarena, 2008), Rhamdella cainguae (Bockmann \& Miquelarena, 2008), Rhamdia enfurnada
(Bichuette \& Trajano, 2005), R. muelleri (Silfvergrip, 1996), and R. guasarensis (DoNascimiento et al., 2004). On the other hand, this segment of the supraorbital laterosensory canal is missing in the majority of the members of the "Clade D" of Bockmann \& Miquelarena (2008), which includes the Nemuroglanis sub-clade plus Brachyglanis, Gladioglanis, Leptorhamdia, and Myoglanis (and probably Phreatobius). Among heptapterids, this apomorphic state has been figured for Gladioglanis machadoi (Ferraris \& Mago-Leccia, 1989), Heptapterus sympterygium (Buckup, 1988), and Nemuroglanis lanceolatus (Bockmann \& Ferraris, 2005). Although not homogeneously present, the $\mathrm{s} 7 \mathrm{branch}$ and pore are found in more than $50 \%$ of specimens of R. krugi (at least on one side of head). Because $R$. krugi has a deep position within the "Clade D" and its congeners lack the s7 branch and pore, this state is likely a reversion.

5) Subpreopercle absent. Almost all members of the subfamily Heptapterinae, as well as several catfish families, have a tubular, membranous ossicle between the anterior extremity of preopercle and the posterior limit of mandible that surrounds the preoperculomandibular laterosensory canal. Among heptapterids, this condition has been illustrated for Brachyrhamdia imitator Myers (Lundberg \& McDade, 1986), Rhamdella aymarae Miquelarena \& Menni (Miquelarena \& Menni, 1999), R. cainguae (Bockmann \& Miquelarena, 2008), and Rhamdia quelen (Silfvergrip, 1996). This state, considered to be plesiomorphic, is also present in $R$. microcephala and R. moreirai. Rhamdiopsis krugi, in contrast, does not have any sign of subpreopercle (Fig. 5). Within heptaterids, this apomorphic state is homoplastically present in Gladioglanis and Phreatobius only. DoNascimiento et al. (2004) did not represent the subpreopercle in their illustration of the suspensorium and jaw of Rhamdia guasarensis, but such an absence deserves further investigation.

6) Anterior and posterior branches of the transverse process 4 co-ossified to each other. In the transverse process of vertebra 4 of $R$. krugi, the posterior border of the anterior branch and the anterior margin of the arborescent portion of the posterior branch are joined to each other via a bony bridge that delimits a large, rounded foramen between them (Fig. 7). The anterior and posterior branches of the transverse process 4 of R. microcephala and R. moreirai, as well as in the most heptapterids (Bockmann, 1998), do not join each other distally. A configuration similar to that of $R$. krugi has been identified as a synapomorphy for three species of Rhamdella (Bockmann $\&$ Miquelarena, 2008), but in view to the most parsimonious scheme of relationships of the family Heptapteridae (Bockmann \& Miquelarena, 2008), this condition is interpreted as a homoplasy.

7) Posterior limb of the transverse process 4 undivided, with spatulated shape. A distinct deep medial notch which divides the anterior portion of posterior branch of the transverse process 4 into two divergent, approximately symmetrical, long arms is a synapomorphy for the Nemuroglanis sub-clade (Bockmann, 1994), a heptapterid 
group that includes $R$. krugi. However, the anterior portion (arborescent portion) of the posterior branch of transverse process of vertebra 4 of the most c\&s specimens of $R$. krugi does not have any notch, having a spatulated aspect instead. The single exception is the smallest c\&s specimen, which exhibits the apomorphic condition on one side. Because $R$. krugi has the majority of the synapomorphies of the Nemuroglanis sub-clade (see above) and the two other species of Rhamdiopsis exhibit the apomorphic condition, the state of $R$. krugi is interpreted as a reversion.

8) Posterolateral corner of the posterior portion of the posterior branch of the transverse process of vertebra 4 extending approximately to midlength of the transverse process of vertebra 5. A laminar portion of the posterior portion of the posterior branch of the transverse process of vertebra 4 with triangular shape and extending nearly to the distal tip of the fifth vertebral transverse process is a synapomorphy for the Nemuroglanis sub-clade (Ferraris, 1988; Bockmann, 1994). This derived state is present in all members of the Nemuroglanis sub-clade, including the congeners of $R$. krugi. Notwithstanding that region of the transverse process of vertebra 4 of $R$. krugi is distinctly triangular, its posterolateral corner only reaches approximately to midlength of the transverse process of vertebra 5 (Fig. 7). This condition, thus, is interpreted as a reversion.

9) Presence of a widely exposed pseudotympanum. One of the most remarkable autapomorphies of $R$. krugi is its peculiar pseudotympanum. Pseudotympanum may be defined as a gap of the hypaxial musculature at anterior portion of body, which exposes the anterior part of the swimbladder. The singularly evident pseudotympanum of $R$. krugi, represented by a well-defined triangular translucent area on anterolateral region of trunk (Figs. 1-2, 3a), is product of a very thin skin coverture associated with a large swimbladder. The lateral limit of the swimbladder of $R$. krugi goes far beyond the external border of the posterior branch of the transverse process of vertebra 4 , conferring a remarkably convex profile to the anterior portion of trunk when seen from above, and its posterior limit extends posteriorly to the vertebral centra 6 or 7 (Fig. 7). The pseudotympanum of $R$. microcephala and $R$. moreirai is not as evident as that of $R$. krugi, being visible only through strong transmitted light, due to a much thicker covering skin and a considerably smaller swimbladder, which is posteriorly limited to the level of vertebral centrum 5 . Bockmann (1994) proposed that a small swimbladder is an autapomorphy for the Nemuroglanis sub-clade, a group that includes $R$. krugi (see above). The condition of $R$. krugi is, thus, interpreted as a reversion.

Pseudotympanum presumably facilitates sound transmission from the environment to the swimbladder wall, and then to the inner ear through the Weberian apparatus (Malabarba, 1998). Differing from the remaining heptapterids, which are mainly associated to the bottom of lotic shallow waters, $R$. krugi dwells in lentic waters, exploring a wide vertical range of the water column (Trajano \& Bockmann, 1999a). In the Poço Encantado lake, R. krugi occurs mostly between the surface and $10 \mathrm{~m}$, but it has been reported as deep as $34 \mathrm{~m}$ (Mendes, 1995a; Trajano, 2001a). A large and widely exposed pseudotympanum seems to be characteristic of small-sized otophysan fishes which inhabit calm waters (as it is the case of R. krugi), like the characins of the subfamily Cheirodontinae (Malabarba, 1998) and of the genera Charax Scopoli (Galvis et al., 1989; Winemiller, 1989; Malabarba, 1998; Menezes et al., 2007), Phenacogaster Eigenmann (Malabarba \& Lucena, 1995), and Roeboides Günther (Sazima \& Machado, 1982; Lucena, 2000, 2007; Hoeinghaus et al., 2004), and a few species of the genus Characidium Reinhardt (Crenuchidae), such as C. lagosantense Travassos and similar forms (Travassos, 1947; Buckup, 1998; Castro et al., 2004). The pseudotympanum of individuals of $R$. krugi may serve as a device for improving hearing in deep and dark waters where they live, facilitating them to find the scarcely available preys (Trajano, 2001a) and to meet each other for mating, and other kinds of social interactions.

10) Posterior lobe of the adipose fin straight. The adipose fin of catfishes usually ends in a free, rounded lobe. This condition is present in most members of the Heptapteridae, being discernible even when the adipose fin is partially fused to the dorsal fold of caudal fin. Two basal thirds of the posterior portion of adipose fin of $R$. microcephala are fused to the dorsal caudal-fin fold, leaving a discrete posterior free lobe, while the posterior lobe of adipose fin of $R$. moreirai is mostly free (Lütken, 1875; Haseman, 1911; pers. obs.). Despite of these differences, the posterior limit of adipose fin has a distinct rounded contour in both species. The posterior border of adipose fin of R. krugi is basally confluent with the caudal fin, but its free portion has a marked straight contour (Figs. 1, 12-13). This condition is unique among heptapterids, being considered an autapomorphy for this species.

11) Anal fin deep and rounded. The anal fin of heptapterids is usually low and rectangular, a configuration produced by relatively short rays with approximate similar depth across the fin length. This is also the condition exhibited by $R$. microcephala and R. moreirai (Lütken, 1875; Haseman, 1911), the closest relatives of $R$. krugi. The anal fin of $R$. krugi is deep and has a singular rounded shape, produced by its long rays at the midlength of the fin (Figs. 1, 12-13). This characteristic is likely a modification functionally related to its pelagic behavior.

12) Hypural 5 usually co-ossified to hypural 4 at its distal portion. Having an autogenous hypural 5 is the widespread condition through heptapterids, and it is considered plesiomorphic in siluriforms (Lundberg \& Baskin, 1969; Bockmann \& Ferraris, 2005). In the most specimens of R. krugi, the hypural 5 is partially fused with hypural 4, usually at its distal portion only (Fig. 11a), being rarely co-ossified with this element into a single dorsal caudal plate (Fig. 11b) or completely independent. A complete fusion of the hypural 5 with hypural 4 into a single complex plate (which also includes hypural 3 ) is found in Gladioglanis, Nemuroglanis, Phreatobius, and in a monophyletic group composed of three species of Rhamdella (Bockmann \& Ferraris, 2005; Bockmann \& Miquelarena, 2008). 
These states, however, are considered homoplastic in relation to that of $R$. krugi, because all those taxa are distantly related to this species (Bockmann, 1998; Bockmann \& Miquelarena, 2008 ) and its congeners $R$. microcephala and $R$. moreirai have a separate hypural 5 . Interestingly, the troglobitic ictalurid genera Prietella Carranza, Satan Hubbs \& Bailey, and Trogloglanis Eigenmann have dorsal hypurals completely fused (Lundberg \& Baskin, 1969; Lundberg, 1982).

13) Dorsal hypural plate typically with 7 rays. The dorsal hypural plate of most siluriforms, composed of hypurals 3, 4, and 5, bears commonly eight rays (Lundberg \& Baskin, 1969; Bockmann \& Ferraris, 2005 treated it as "dorsal caudal plate"). This plesiomorphic configuration is exhibited by the majority of members of the Heptapteridae (Bockmann, 1998), including $R$. microcephala and $R$. moreirai. In contrast, the dorsal hypural plate of $R$. krugi supports 7 (22) rays (Fig. 11), rarely 6 (1) or 8 (1) rays. The same state is also reported in Cetopsorhamdia boquillae Eigenmann \& Fisher, Gladioglanis conquistador Lundberg, Bornbusch \& Mago-Leccia, Heptapterus mustelinus, H. sympterygium, "Imparfinis" borodini Mees \& Cala, "I." hollandi Haseman, "I." pristos Mees \& Cala, and Pariolius (Bockmann \& Ferraris, 2005). Further derived states are observed in Horiomyzon, Nemuroglanis lanceolatus, $N$. pauciradiatus, and Phreatobius (Bockmann \& Ferraris, 2005). All those apomorphic conditions are interpreted as homoplasies in relation to that of $R$. krugi, considering the current phylogeny of the Heptapteridae (Bockmann \& Miquelarena, 2008).

14) Dorsal caudal-fin lobe typically with 6 branched rays. Siluriforms plesiomorphically have seven branched rays in the dorsal caudal-fin lobe (Lundberg \& Baskin, 1969). Rhamdiopsis krugi has apomorphically 6 (19), rarely 4 (1), 5 (3) or 7 (1) branched rays in the dorsal caudal-fin lobe. The plesiomorphic state is present in $R$. microcephala (only one of six specimen has 6 branched rays in the dorsal caudal-fin lobe) and $R$. moreirai. Six branched rays in dorsal caudal-fin lobe are also found in Cetopsorhamdia boquillae, Gladioglanis machadoi, Heptapterus mustelinus, "Imparfinis" borodini, "I." hollandi, "I." pristos, Myoglanis potaroensis Eigenmann, and Phenacorhamdia unifasciata Britski (Bockmann, 1998). Five or less branched rays on dorsal caudal-fin lobe occur in Gladioglanis conquistador, Heptapterus sympterygium, Horiomyzon, Nemuroglanis lanceolatus, N. pauciradiatus, Pariolius, and Phreatobius (Bockmann, 1998; Bockmann \& Ferraris, 2005). These states are probably convergent in relation to that of $R$. krugi, considering the current cladogram of the Heptapteridae (Bockmann \& Miquelarena, 2008).

15) Ventral caudal plate typically with 6 rays. As discussed above, ventral caudal plate with 6-7 rays is a putative synapomorphy for $R$. krugi and $R$. moreirai. Rhamdiopsis krugi has a slightly further advanced state, with 6 (17) rays, less commonly 7 (7) rays, articulated to the ventral caudal plate (Fig. 11), whereas $R$. moreirai presents always 7 rays.

16) Ventral caudal-fin lobe typically with 6 branched rays. Eight rays of the ventral caudal-fin lobe are primitively branched in siluriforms (Lundberg \& Baskin, 1969). Among heptapterids, this plesiomorphic state is widespread in various, not-closely related lineages (Bockmann, 1998; Bockmann \& Ferraris, 2005). Either less or more than 8 rays are considered apomorphic states (Bockmann \& Ferraris, 2005). Among heptapterids, Acentronichthys, Heptapterus mustelinus, "Imparales" panamensis Bussing, "Imparfinis" pristos, Rhamdioglanis, and Taunayia have normally 7 branched rays in the ventral caudal-fin lobe. Rhamdiopsis krugi has a further derived condition, usually bearing 6 branched rays in the ventral caudal-fin lobe. This condition is also present in Gladioglanis machadoi, Horiomyzon, Imparfinis borodini, I. hollandi, Nemuroglanis mariai, and Myoglanis potaroensis (Bockmann, 1998; Bockmann \& Ferraris, 2005). Further derived states, 5 or less branched rays in the ventral caudal-fin lobe, are found in Gladioglanis conquistador, Heptapterus sympterygium, Nemuroglanis lanceolatus, N. pauciradiatus, Pariolius, and Phreatobius (Bockmann, 1998; Bockmann \& Ferraris, 2005). Considering the cladogram of the Heptapteridae (Bockmann \& Miquelarena, 2008) and the fact that the congeners of $R$. krugi have 7 or more branched rays in the ventral caudal-fin lobe (viz. 7-8 in R. microcephala and 8-9 in R. moreirai), the occurrence of the apomorphic state in $R$. krugi is considered homoplastic in relation to those of other taxa.

17) Lateral line very short, with $5-15$ pores, usually reaching the region from the posterior limit of pseudotympanum to the dorsal-fin origin. In the majority of catfishes, the lateral line extends to the middle of the caudalfin lobes (Lundberg, 1992). As mentioned before, even though being long, the lateral line of Rhamdiopsis microcephala and $R$. moreirai is fragmented in several points and falls short of the posterior half of adipose fin. In R. krugi the extension of the lateral line is drastically smaller (Figs. 3a, 7), as first pointed out by Trajano \& Bockmann (2000), reaching posteriorly, in the most extreme condition, to the vertical through the end of dorsal fin. The reduction of lateral line as a whole is a putative synapomorphy for Rhamdiopsis (see above), and the state of $R$. krugi likely represents a terminal step in the transformation series (see above). Similar but certainly homoplastic conditions are exhibited by Nemuroglanis lanceolatus, N. pauciradiatus, and Pariolius, in which the lateral line extends to the middle of dorsal-fin base (Bockmann, 1998; Trajano \& Bockmann, 2000; Bockmann \& Ferraris, 2005). An even shorter lateral line occurs in the heptapterids Gladioglanis, Heptapterus sympterygium, Phreatobius, and Taunayia sp. from Campo Formoso, State of Bahia, in which it extends to a point just anterior to the dorsal-fin origin (Reichel, 1927; Buckup, 1988; Ferraris \& Mago-Leccia, 1989; Lundberg et al., 1991; Shibatta et al., 2007; pers. obs.). A short and interrupted lateral line is not a common trait among troglobitic heptapterids, such as exemplified by Pimelodella spelaea (Trajano et al., 2004), Rhamdia enfurnada (Bichuette \& Trajano, 2005), R. guasarensis (DoNascimiento et al., 2004), and $R$. laluchensis (Weber et al., 2003), which have long and complete lateral lines. The lateral line of cave-dwelling ictalurids Satan and Trogloglanis is also short, not exceeding the end of adipose fin (Langecker \& Longley, 1993). 
18) Fatty tissue broadly spread through the body. Large deposits of adipose tissue in different body parts were observed in many wild troglobitic fishes (Trajano, 2001a). The head and trunk of $R$. krugi are widely filled by small, rounded fatty corpuscles, mainly visible through the base of fins, and opercular, branchiostegal, pectoral, and abdominal regions. Most catfishes, including heptapterids, have fatty tissues concentrated in particular areas of body, as in the axillary region (Bockmann, 1994). The apomorphic state seems to be widespread among troglobitic heptapterids, inasmuch as ridges of fat have been reported along the fin bases of Pimelodella kronei, Rhamdia reddelli, R. macuspanensis, and $R$. zongolicensis (Wilkens, 1993; Weber \& Wilkens, 1998; Trajano, 2001a). The presence of large adipose deposits in the hypodermis is common in subterranean catfishes, as it can be observed in troglobitic ictalurids (Lagencker \& Longley, 1993). This characteristic is suggested to be caused by selection pressure on energy economy in the generally food-limited cave environment (Lagencker \& Longley, 1993). The high lipid content results in a decrease of specific gravity (Lagencker \& Longley, 1993), which may improve the buoyancy across the water column in the case of R. krugi.

19) Adults of small body size, reaching $38.5 \mathrm{~mm}$ SL. Despite the family Heptapteridae to be a group chiefly constituted by small catfishes, most of its species are larger than $5 \mathrm{~cm} \mathrm{SL}$ (Bockmann \& Guazzelli, 2003). Trajano \& Bockmann (1999a) pointed out that, among the subterranean heptapterids, small body size is a derived, independent characteristic of Phreatobius, R. krugi (treated as "new genus, new species"), and Taunayia sp. from Campo Formoso, State of Bahia, Brazil, with the most extreme condition in the two latter taxa (usually less than $50 \mathrm{~mm}$ TL). The genera Gladioglanis, Horiomyzon, Nemuroglanis (including Imparales Schultz and Medemichthys Dahl as its junior synonyms - see Bockmann $\&$ Ferraris, 2005), and Pariolius, with up to $3.9 \mathrm{~cm} \mathrm{SL}$, are miniature heptapterids (Bockmann \& Guazzelli, 2003). The slightly larger Phreatobius, with up to $5.5 \mathrm{~cm} \mathrm{SL}$ (Bockmann \& Guazzelli, 2003; Muriel-Cunha \& de Pinna, 2005), fits in the category of "elongate miniature" (Weitzman \& Vari, 1988). Because all these taxa are not closely related to R. krugi (Lundberg et al., 1991; Bockmann, 1994, 1998; Bockmann \& Ferraris, 2005), and its congeners are considerably larger ( $R$. microcephala and R. moreirai reach 78.0 and $117.0 \mathrm{~mm} \mathrm{SL}$, respectively; Bockmann \& Guazzelli, 2003), the small size of R. krugi is considered homoplastic. Small size seems to be a generalized feature among blind fishes, being probably caused by selection pressure on energy economy in the generally food-limited cave environment (Lagencker \& Longley, 1993).

20) Body coloration absent. The body of the most members of the Heptapteridae is heavily pigmented, including that of $R$. moreirai and R. microcephala. Rhamdiopsis krugi is distinct from this plesiomorphic pattern in having no trace of dark pigmentation (Figs. 1-2, 12-13). Such an extreme condition is also found in Phreatobius dracunculus and in the undescribed species of Taunayia from Campo Formoso, State of Bahia, Brazil (Trajano \& Bockmann, 2000; Shibatta et al.,
2007). Phreatobius cisternarum and $P$. sanguijuela are almost depigmented but they retain some faint dark integumentary pigmentation (Muriel-Cunha \& de Pinna, 2005; Fernandez et al., 2007). The integumentary pigmentation in other troglobitic heptapterids is highly variable, but it is always present at some degree (Trajano et al., 2004; Bichuette \& Trajano, 2005). Within the non-troglobitic heptapterids, Zuanon et al. (2006) considered the scarce body pigmentation of Horiomyzon, "Imparfinis" pristos, Mastiglanis, and "Nannorhamdia" stictonotus Fowler as an apomorphy possibly related to camouflage on sandy bottoms. These species belong to the "Imparfinis clade", a monophyletic group that does not include R. krugi (Bockmann \& Ferraris, 2005; Zuanon et al., 2006). Therefore, the complete absence of body pigmentation of $R$. krugi is thought to be an independent acquisition, being thus interpreted as an autapomorphy.

21) Non-cryptobiotic behavior, expressed by marked midwater activity. Most heptapterids, in higher or lesser degree, have cryptobiotic habits, being predominantly nocturnal. Basal lineages of the Heptapteridae (Bockmann \& Miquelarena, 2008), such as Brachyrhamdia and Pimelodella, frequently explore the middle of water column (Trajano \& Bockmann, 1999a), which it may represent the plesiomorphic state. On the other hand, members of the heptapterid "Clade D" of Bockmann \& Miquelarena (2008), which encompasses the Nemuroglanis sub-clade plus Brachyglanis, Gladioglanis, Leptorhamdia, and Myoglanis (and likely Phreatobius), are mainly bottom-dwellers and typically hides most of time, living in confined spaces formed by rocks and boulders (e.g., Chasmocranus, Heptapterus, Leptorhamdia, Phenacorhamdia, and Rhamdioglanis), leaf litter (e.g., Gladioglanis, Nemuroglanis, Pariolius, and Phreatobius), and sand (e.g., "Imparfinis" pristos, Mastiglanis, and "Nannorhamdia" stictonotus). Rhamdiopsis microcephala and R. moreirai, as well as Acentronichthys, are found entrenched inside the marginal vegetation (Bockmann \& Guazzelli, 2003; Abilhoa \& Duboc, 2004; Bockmann \& Castro, 2008). Most heptapterids are active mainly at night (Costa, 1987; Casatti \& Castro, 1998). Conversely, R. krugi has cryptobiotic habits weak or absent, as expressed by its behavior of exploring the water column and surface (Trajano, 1993, 2001a; Mendes, 1995b; Trajano \& Bockmann, 1999a, 2000). Increased midwater activity is also observed in the troglobitic heptapterids Pimelodella kronei, Phreatobius cisternarum, Rhamdia enfurnada, and Taunayia sp. from Campo Formoso, State of Bahia, Brazil (Trajano \& Bockmann, 1999a; Bichuette \& Trajano, 2005), but these conditions are probably homoplastic.

22) Non-photophobic behavior. Rhamdiopsis krugi shows no photophobic reaction when illuminated (Trajano \& Gerhard, 1997; Trajano \& Bockmann, 1999a). This apomorphic characteristic is also present in Taunayia sp. from Campo Formoso, State of Bahia, Brazil (Trajano \& Gerhard, 1997; Trajano \& Bockmann, 1999a), another troglobitic heptapterid that lacks eyes completely. In Pimelodella kronei and Rhamdia enfurnada, heptapterids 
with troglomorphisms in intermediary degree of development, the light sensitivity is variable (Trajano \& Gerhard, 1997; Bichuette \& Trajano, 2005). Although the photosensibility of heptapterids remains to be more evaluated in a wider taxonomic sample, epigean members of distinct lineages, viz. Chasmocranus lopezi MirandaRibeiro, "Imparfinis" hollandi, Imparfinis sp., Pimelodella transitoria Miranda-Ribeiro, Rhamdia laticauda, R. quelen, Rhamdioglanis frenatus Ihering, and Taunayia bifasciata (Eigenmann \& Norris), are highly photophobic (Pavan, 1946; Sazima \& Pombal Jr., 1986; Langecker, 1992; Trajano \& Gerhard, 1997; Trajano \& Bockmann, 2000). Bichuette (2004) observed, during a snorkeling session in the Poço Encantado, that R. krugi avoids the light of underwater electric lamps. However, we believe that extensive observations made in laboratory under controlled experimental conditions are more reliable than that made in the field under water, certainly more subject to observer interference.

23) Poorly-developed circadian rhythms. Eyed heptapterids have marked circadian components, a condition assumed to be plesiomorphic (Trajano \& Menna-Barreto, 1995, 2000; Trajano \& Bockmann, 1999a). Experiments aiming to evaluate the locomotor activity of $R$. krugi (from Poço Encantado and Gruta Natal caves), have pointed out for the absence of significant circadian components under constant darkness (Trajano \& Menna-Barreto, 1995; Trajano et al., 2005). In all cases, important and variable ultraradian rhythms were detected for $R$. krugi, which indicates the residual presence of internal mechanisms of control of the temporal order (Trajano \& Menna-Barreto, 1995; Trajano et al., 2005). Under light-dark condition, $R$. krugi showed strong circadian rhythms, with decreasing activity in the light phases, which probably corresponds to a remanescent behavioral trait inherited from its epigean ancestor (Trajano et al., 2005). This indicates that $R$. krugi, as well as other more specialized, totally blind, cave catfishes exhibits a regression of circadian rhythmicity (Trajano \& MennaBarreto, 1995; Trajano \& Bockmann, 1999a, Trajano et al., 2005).

24) Life in lentic habitat. Most catfishes, including heptapterids, inhabit body waters with medium to fast velocity. Rhamdiopsis krugi is secondarily adapted to lentic conditions (Mendes, 1995a; Trajano \& Bockmann, 1999a, 2000; Trajano, 2001a), which contrasts with the commonly stream-adapted epigean members of the family Heptapteridae (Bockmann \& Guazzelli, 2003). It is interesting to draw attention to the fact that even though $R$. microcephala and $R$. moreirai inhabit fast-flowing rivers, they occur predominantly in protected sectors of rivers, especially in the margins covered with vegetation (Bockmann \& Guazzelli, 2003; Abilhoa \& Duboc, 2004; Bockmann \& Castro, 2008). The habitat preference for calmer waters by $R$. microcephala and $R$. moreirai may represent an intermediary step towards the more extreme condition found in R. krugi.
The degree of development of troglobitic characteristics, especially those related to eyes and pigmentation, has been widely correlated to the time of subterranean evolution (Wilkens, 1986, 1988). Accordingly, the extreme troglomorphisms of $R$. krugi, which are also highly conservative, have lead to assume this species as one of the oldest troglobites of Brazil (Trajano, 1995; Trajano \& Bichuette, 2006; Volpato \& Trajano, 2006). Trajano (2007) estimated an age in the order of $10^{5}-10^{6}$ years for R. krugi. Also supporting an old age for $R$. krugi is its capability to synthesize melanin under the presence of L-DOPA (Trajano \& de Pinna, 1996; Trajano, 2007), which indicates that its paleness was likely reached through a slow, gradual polygenic system (Wilkens, 1988; Trajano, 2007). The occurrence of $R$. krugi in a coastal drainage of eastern Brazil, one of the oldest regions of the South America in geomorphological terms, which harbors a highly endemic and phylogenetically ancient ichthyofauna (Bizerril, 1994; Ribeiro, 2006), should reinforce this view. The discovery of 24 autapomorphies would be definitive to accept the old age of $R$. krugi as an undisputable fact.

Although we also believe that $R$. krugi is phylogenetically older than, for instance, Pimelodella kronei and Rhamdia enfurnada, which have troglomorphisms (eyes and pigmentation) in variable degrees of development, the above arguments should be taken with some caution. First because, as it will be discussed below, the occurrence of $R$. krugi in a coastal drainage of eastern Brazil, the rio Paraguaçu basin, is probably due to a more recent fluvial capture of a section of the rio São Francisco basin. Secondarily, and mainly, because several of its autapomorphies may be related to each other, representing complex evolutionary packages of morphologicalbehavioral characteristics. This is particularly true for characters associated with subterranean environments, which are prone to convergent evolution (Trajano \& Bockmann, 1999a; Trajano, 2003). In this study, we have chosen to treat each feature individually, in the absence of clear-cut criteria to state relationships of dependence between them. However, examples of possibly related characters in $R$. krugi are numerous. One of the most obvious is its life in calm waters (character 24) and exploration of wide range of water column (character 21); this behavioral complex-character may be functionally related to the widely exposed pseudotympanum of $R$. krugi (character 9). The transverse processes of the vertebrae 4 and 5 of $R$. krugi are compact, forming a solid roof for the swimbladder. This morphology, expressed by the anterior and posterior branches of transverse process 4 united to each other (character 6) and posterior limb of the transverse process 4 undivided (character 7), may be resulting from the vertical forces opposed to the effort to explore a wide range of the water column (character 21). The deep and rounded anal fin of $R$. krugi (character 11) may be also functionally related to its pelagic behavior (character 21). Therefore, it is not improbable that at least some of these morphological and behavioral novelties of $R$. krugi have evolved at once rather than through a step-by-step, relatively slower evolutionary model. 
The hypothetical age of Rhamdiopsis krugi may be substantially lowered when paedomorphosis is invoked to explain the origins of its morphological and behavioral complex features. In this sense, these attributes of R. krugi may have been achieved by simple deletion of terminal stages or change in the timing of development (heterochrony) of the plesiomorphic ontogenetic series, as opposed to an evolutionary model envolving terminal additions only. The small size (character 19) and non-cryptobiotic habits, with increased midwater activity (character 21) of $R$. krugi have been suggested as juvenile traits retained by the adults (e.g., Trajano \& Bockmann, 1999a; Trajano, 2001a). Furthermore, at least seven other putatively derived features of $R$. krugi may have their origins explained by paedomorphosis: supraorbital and infraorbital laterosensory canals anteriorly not connected to each other (character 3), subpreopercle absent (character 5 ), fewer rays on dorsal hypural plate and on ventral caudal plate (characters 13 and 15, respectively), fewer branched caudal-fin rays (characters 14 and 16), and lateral line short and interrupted (character 17).

Some troglobitic catfishes have evolved specializations similar to those present in deep-sea fishes (sometimes called "deep sea syndrome"; Poulson, 1971; Langecker \& Longley, 1993), including tiny eyes, elaborated extra-optic sensory systems, large lipid deposits, and small body size (Poulson, 1971, 2001). All these characteristics are found in R. krugi (characters 2, 9, 18, and 19, respectively), especially if its widely exposed pseudotympanum is proven to be an effective device for improving hearing. The troglobitic ictalurid catfishes Satan and Trogloglanis, from the Edwards Aquifer in Texas, further share some extreme specializations found in bathypelagic deep-sea fishes, viz. very small swimbladder, with the space usually occupied by a normal-sized structure filled with prominent fat deposits, and poorly developed muscles and skeleton (Lundberg, 1982; Langecker \& Longley, 1993). Instead, R. krugi has a body robustly built, with welldeveloped muscles and strongly ossified skeleton, and an ample swimbladder, in fact even larger than that of the most epigean heptapterids. These differences may be understood as distinct adaptations to life in quite different microhabitats, with Satan and Trogloglanis being predominantly bottomdwellers (especially Trogloglanis; see Langecker \& Longley, 1993) and $R$. krugi exploring a broad range of the water column.

The enhancement of sensory structures other than the vision is a common phenomenon among animals inhabiting strictly subterranean environments (Marques \& Gnaspini, 2001; Bichuette \& Trajano, 2005). Besides the pseudotympanum, the barbel, known site for chemo- and mechanosensory sensations, is the only other structure of $R$. krugi larger than that of its congeners. Such a difference, although subtle, can be illustrated by the ranges of length of the maxillary barbel: $R$. krugi is $32.2-43.3 \% \mathrm{SL}$ (mean $=36.1$, $\mathrm{SD}=2.1, \mathrm{~N}=19$ ) whereas that of $R$. microcephala and $R$. moreirai is $21.2-29.3 \% \mathrm{SL}$ (mean $=26.1, \mathrm{SD}=3.4, \mathrm{~N}=5$ ) and $18.9-28.6 \% \mathrm{SL}$ ( mean $=24.7, \mathrm{SD}=2.9, \mathrm{~N}=12$ ), respectively. No other distinct sensory structure, like dense concentration of sensory papillae on skin or neuromast lines, is noticeable in $R$. krugi. Although the laterosensory canals of the head of $R$. krugi have a relatively broad caliber, they do not differ from those of $R$. microcephala and R. moreirai. Instead, the lateral line is poorly developed when compared to that of its congeners (see above). Under experimental conditions, $R$. krugi did not show generalized phobic reactions, being not photophobic and reacting to most stimuli, as those from water movements and sudden illumination (Trajano, 1993, 1996; Trajano \& Gerhard, 1997; Trajano \& Bockmann, 1999a). Therefore, it is reasonable to consider that the pseudotympanum of $R$. krugi actually works as an important component for enhancing its hearing ability, a hypothesis that deserves further investigation.

Biogeography of Rhamdiopsis krugi. The genus Rhamdiopsis, as here defined, is distributed through the area drained by the upper rio São Francisco, southeastern Brazil (R. microcephala); upper rio Iguaçu, southern Brazil, and upper rio Ribeira de Iguape, southeastern Brazil (R. moreirai); and upper rio Paraguaçu, northeastern Brazil (R. krugi). As discussed before, at current state of knowledge, it is not possible to access the sister group of $R$. krugi so that the relationships between those sub-areas are uncertain. An ongoing revisionary and phylogenetic investigation of Rhamdiopsis has revealed the existence of at least 17 valid species (Bockmann \& Castro, in prep.), most of them occurring across the region of the Brazilian Shield drained by the rio Paraná and upper rio São Francisco basins. Rhamdiopsis krugi is an exception, being confined to the upper rio Paraguaçu basin, which belongs to the region comprising the coastal drainages of eastern Brazil (Bizerril, 1994; Ribeiro, 2006). Besides R. krugi, four other species of Rhamdiopsis occur in that area: an isolated population of $R$. moreirai that is restricted to the upper reaches of the rio Ribeira de Iguape (Abilhoa \& Duboc, 2004), a new species from the rio Paraibuna basin, a left side tributary of the rio Paraíba do Sul (Bizerril, 1999), a new species from the upper rio Paraguaçu basin (Santos, 2005; Santos \& Caramaschi, 2007), and a new species from the upper reaches of the rio Jequitinhonha (pers. obs.). Although all these species live in coastal rivers of eastern Brazil, it is noticeable that they inhabit only their most interior versants. Such a distribution suggests that non-litoraneous segments of at least these four principal river basins from the system of coastal drainages of eastern Brazil have closer affinities with the adjacent portions of the rio Paraná and rio São Francisco basins than with their own mid and lower courses. Concerning the rio Paraguaçu basin, this situation is highlighted by the discovery of a high number of species in the upper reaches of the river that were previously known only from interior basins or with close phylogenetic relationships to lineages inhabiting these interior drainages (Santos \& Caramaschi, 2007), for example: Apareiodon hasemani Eigenmann and Phenacogaster franciscoensis Eigenmann, both considered endemic to the rio São Francisco basin (Lucena \& Menezes, 2003; Pavanelli, 2003), Moenkhausia diamantina Benine, 
Castro \& Santos, that is probably related to a species-group whose members live in the drainages of Guyanas, and Amazon, Orinoco, Paranaíba, São Francisco, Paraná, Paraguay, and Uruguay basins (Lima et al., 2003; Benine et al., 2007), Trichomycterus cf. brasiliensis, that possibly pertains to $T$. brasiliensis species-complex, which is distributed through the upper rio Paraná, upper reaches of the rio São Francisco, rio Paraíba do Sul, and rio Ribeira do Iguape (Bockmann \& Sazima, 2004), and Pamphorichthys hollandi (Henn), known from the rio São Francisco, rio Parnaíba and upper rio Paraná basins (Figueiredo, 1997; Lucinda, 2003; Casatti et al., 2006). The hybrid conformation of rio Paraguaçu is likely due to river capture processes (Ribeiro et al., 2006), controlled by tectonic fault systems in the region of Chapada Diamantina, although which events that generated it and their ages cannot be determinated at this moment.

According to Castro \& Trajano (1993), during dry periods, the overall sinking of water table led to interruption of the straight contact between the subterranean drainage and the epigean habitat, causing the geographical isolation of the hypogean populations. The occurrence of $R$. krugi in three, probably more caves relatively distant from each other poses an interesting biogeographical problem. It is improbable that all 24 autapomorphies developed independently at least three times, even considering that several are troglomorphisms (then, susceptible to parallel evolution). Therefore, it is quite possible that the water bodies inside those caves where $R$. krugi occurs are, or were connected to each other through aquifers inaccessible to humans (Mendes, 1995c; Trajano, 1997b, 2001a). This is further indicated by the fact that variations in water level of the lakes inside the Poço Encantado, Lapa do Bode, and Gruta Natal follow those observed in the rio Una (Karmann et al., 2002).

Trajano (1995) correlated the origin of troglobitic fauna in the tropical South America with the Quaternary climatic fluctuations. During the humid, interglacial fluctuations periods the forests expanded, allowing the cave ancestors to colonize most karstic areas, becoming trogophiles. In the dry, glacial periods, the forests retreated and many epigean water bodies dried up, isolating cave populations in areas not situated in mesic refuges. The most specialized troglobites will be found in presently arid regions, where the total time of isolation is probably longer. Heptapterids are known to have close association with humid forested areas (Bockmann \& Guazzelli, 2003). This is the case of $R$. microcephala and $R$. moreirai (Bockmann \& Castro, 2008), the two congeners of $R$. krugi. Thus, it is possible that, during the humid cycle, the semi-arid region where presently $R$. krugi occurs was covered by a wide forest that retreated in the past.

Notes on morphological plasticity of Rhamdiopsis krugi. Specimens of $R$. krugi show a high number of morphological variation, while abnormalities are also not rare. Variation in $R$. krugi occurs in several distinct morphological complexes in an uncommon high ratio, even in characteristics that are thought being very conservative, as number and branching pattern of rays on dorsal caudal-fin lobe and number of dorsalfin rays. Large series of heptapterids have been examined by the first author, including the closest relatives of $R$. krugi, $R$. microcephala and $R$. moreirai, and no parallel plasticity has been recorded. Variation was found, for example, in the morphology of the ethmoidean cartilage, pattern of branching and number of pores of the laterosensory cephalic canal system, pattern of fragmentation of the second distal radial of the pectoral fin, degree of ossification of hypo- and basibranchials, degree of fusion of hypurals 5 and 4, number and branching pattern of rays articulated to the caudal plates. The range of variation of the body proportions is also much higher than that usually found in heptapterids (Table 1). In characters known to be prone to variation, like the number of pectoral-, anal-, and caudal-fin rays, the range is remarkably wider than that commonly seen among heptapterids. Bilateral asymmetry is also commonly observed in $R$. krugi. Abnormalities are commonplace in $R$. krugi, as exemplified by the blunt posterior process of the lateral ethmoid (Fig. 4) and the multibranched uroneural (Fig. 11b).

The dramatic change in the ecological parameters, which must have occurred when the epigean ancestor of $R$. krugi left the open riverine habitat to the cave environment, may be partially responsible for its wide range of morphological variation (including, as extreme conditions, its abnormalities). A similar situation has been observed in artificial conditions, where modifications in ecological parameters have induced a high number of abnormalities in early stages of cultured fishes (see Hattori et al., 2003, and references therein; pers. obs.). Although rarely commented in the literature, morphological variation and abnormalities are common among subterraneous fishes, and even in cavernicolous, nontroglobitic populations (Poly \& Boucher, 1996). Deformities are frequent in the trichomycterid catfish Trichomycterus itacarambiensis Trajano \& de Pinna, especially in larger individuals (E. Trajano, pers. comm.). Skeletal abnormalities and associated morphological changes have been demonstrated for epigean characin Astyanax mexicanus (De Filippi) reared in darkness for many months; with hormonal imbalance due to lack of light being considered the cause of the abnormalities (Rasquin \& Rosenbloom, 1954; Poly \& Boucher, 1996). The epigean ancestor of $R$. krugi, as it can be inferred from the observed life style of its congeners and the majority of heptapterids, likely inhabited confined spaces of the benthic zone in backwaters of the fastflowing rivers with riparian vegetation, submitted to a moderate illumination. The shift of the ancestor of $R$. krugi to a habitat with steady waters and totally or partially deprived of light may have caused "side-effects" especially to the individuals in their earlier stages of development, generating greater variation and, in most extreme conditions, anomalies.

Culver \& Wilkens (2000) commented upon the reduction of the stabilizing selective pressures on optic, and other lightdependent features of cave organisms, and how this may help to explain the high variability of the biologically functionless vestigial structures in cave species. Relaxing of 
stabilizing selective pressures produced by the lack of predators could explain the wide range of variation and abnormalities of other morphological characteristics of $R$. krugi, which otherwise would be eliminated. Structural mutations are not selected against, and some, due to chance alone, will increase in frequency in the population. The uncommonly high incidence of morphological variations and abnormalities in R. krugi may be also understood as an effect of its greater survival ratio. Deep lakes inside the dark caves of the Chapada Diamantina, where $R$. krugi lives, are habitats distinctly more stable and simpler than those where its epigean relatives are found. Accordingly, predators of R. krugi are missing, competition for food and space is low, and cannibalism is apparently absent (Trajano \& Bockmann, 2000; Trajano, 2001a), which might have loosed the ancestral selective pressures, allowing the survival in higher proportions of individuals with extralimital variations and even abnormalities, which otherwise not succeed to occur.

Comparative material. Rhamdiopsis microcephala (all collected in Brazil, State of Minas Gerais, upper rio São Francisco basin): MCP 34712, 6, 25.9-46.9 mm SL; MZUSP 23209, 2, 53.1-61.9 mm SL; UFRJ 559, 3, 29.7-47.7 mm SL; UFRJ 0708, 1 c\&s (36.4 $\mathrm{mm} \mathrm{SL})$; ZMUC 325, 1 (77.5 mm SL), syntype of Rhamdia microcephala. Rhamdiopsis moreirai (all collected in Brazil, State of Paraná): FMNH 54372 (ex CM 2849, type), 77.4 mm SL, holotype, upper rio Iguaçu basin; FMNH 54373 (ex CM 2849, cotype), $55.0 \mathrm{~mm}$ SL, paratype, upper rio Iguaçu basin; MCP 14513, 3, 34.1-39.3 mm SL, 1 c\&s, $39.3 \mathrm{~mm} \mathrm{SL}$, upper rio Iguaçu basin; MNRJ 19535, 3, 38.5-47.9 mm SL, upper rio Iguaçu basin; MHNCI $6086,1,117.4 \mathrm{~mm}$ SL, rio Ribeira de Iguape basin; MZUSP 68713, 3, 47.8-66.5 mm SL, rio Ribeira de Iguape basin.

\section{Acknowledgements}

We are indebted to the following individuals and institutions for the loan and exchange of specimens, hospitability during visits to their institutions, and various other kinds of assistances: Vinícius Abilhoa, Heraldo A. Bristki, Marcelo R. de Carvalho, Barry Chernoff, Wilson J. E. M. da Costa, José L. de Figueiredo, Carlos A. S. Lucena, Zilda M. S. Lucena, John G. Lundberg, Jorgen Nielsen, Osvaldo T. Oyakawa, Mário C. C. de Pinna, Roberto E. Reis, and Mary Anne Rogers. Special thanks are due to Pedro Gnaspini Neto, Luiz Krug, Liana de F. Mendes, Hertz F. dos Santos, P. Schwartz, and Eleonora Trajano for helping to collect the type series of this species. Maria Elina Bichuette, Liana de F. Mendes, and Eleonora Trajano shared with us precious information and literature. We are very grateful to Mário C. C. de Pinna for allowing the use of $\mathrm{X}$-ray equipment under his care at the MZUSP and Eduardo Baena by taking the radiographs. Hertz F. dos Santos cleared and stained some paratypes of the new species. Murilo de Carvalho and Aléssio Datovo helped in editing the figures. Adriano Gambarini kindly allowed the reproduction of his photographs of a live specimen of $R$. krugi kept in aquarium and the type locality of the new species. The manuscript was greatly benefited from comments and suggestions by Marcelo R. Britto, John G. Lundberg, and one anonymous reviewer. This paper is part of the Program BIOTA/FAPESP through the project "Sistemática, revisão taxonômica e biogeografia da tribo Heptapterini Gill, 1861 (Ostariophysi, Siluriformes, Heptapteridae)"(FAPESP, Proc. No. 03/03108-5). Support from the Projects "Fauna subterrânea aquática brasileira: biodiversidade, biologia, evolução, ecologia e conservação" (FAPESP Proc. No. 03/00794-5) and "All Catfish Species Inventory" (NSF DEB 0315963) is also gratefully acknowledged. Both authors are supported by CNPq (Proc. No. 309291/2007-0 to FAB and Proc. No. 309632/2007-2 to RMCC).

\section{Literature Cited}

Abilhoa, V. \& L. F. Duboc. 2004. Peixes. Pp. 579-678. In: Mikich, S. B. \& R. S. Bérnils (Eds.). Livro Vermelho da Fauna Ameaçada no Estado do Paraná. Curitiba, Instituto Ambiental do Paraná, xvi, 764p.

Arratia, G. 1987. Description of the primitive family Diplomystidae (Siluriformes, Teleostei, Pisces): morphology, taxonomy and phylogenetic implications. Bonner Zoologische Monographien, 24: 1-120.

Arratia, G. \& L. Huaquín. 1995. Morphology of the lateral line system and of the skin of diplomystid and certain primitive loricarioid catfishes and systematic and ecological considerations. Bonner Zoologische Monographien, 36: 1110.

Benine, R. C., R. M. C. Castro \& A. C. A. Santos. 2007. A new Moenkhausia Eigenmann, 1903 (Ostariophysi: Characiformes) from Chapada Diamantina, rio Paraguaçu Basin, Bahia, Northeastern Brazil. Neotropical Ichthyology, 5(3): 259-262.

Bichuette, M. E. 2004. Preliminary data about the distribution and ecology of subterranean heptapterid catfishes from Chapada Diamantina, northeastern Brazil (Ostariophysi: Siluriformes). P. 73. In: Pati, A. K., R. K. Pradhan, A. Parganiha \& A. Agrawal (Eds.). XVII International Symposium on Biospeleology, Raipur, India, 25-30 November 2004, Abstracts. Raipur, Société Internationale de Biospéologie/Pt. Ravishankar Shukla University, 109p.

Bichuette, M. E., M. C. C. de Pinna \& E. Trajano. 2008. A new species of Glaphyropoma: the first subterranean copionodontine catfish and the first occurrence of opercular odontodes in the subfamily (Siluriformes: Trichomycteridae). Neotropical Ichthyology, 6(3): 301-306.

Bichuette, M. E. \& E. Trajano. 2005. A new cave species of Rhamdia (Siluriformes: Heptapteridae) from Serra do Ramalho, northeastern Brazil, with notes on ecology and behavior. Neotropical Ichthyology, 3(4): 587-595.

Bichuette, M. E. \& E. Trajano. 2008. Ituglanis mambai, a new subterranean catfish from the karst area of Central Brazil, rio Tocantins basin (Siluriformes: Trichomycteridae). Neotropical Ichthyology, 6(1): 9-15.

Bizerril, C. R. S. F. 1994. Análise taxonômica e biogeográfica da ictiofauna de água doce do leste brasileiro. Acta Biologica Leopoldensia, 16(1): 51-80.

Bizerril, C. R. S. F. 1999. A ictiofauna da bacia do rio Paraíba do Sul. Biodiversidade e padrões biogeográficos. Brazilian Archives of Biology and Technology, 42 (2): 233-250. 
Bockmann, F. A. \& R. M. C. Castro. 2008. Rhamdiopsis microcephala (Lütken, 1874). Pp. 208-209. In: Machado, Â. B. M., G. M. Drummond \& A. P. Paglia (Eds.). Livro Vermelho da Fauna Brasileira Ameaçada de Extinção. Brasília/Belo Horizonte, Ministério do Meio Ambiente/Fundação Biodiversitas, 1420p.

Bockmann, F. A. 1994. Description of Mastiglanis asopos, a new pimelodid catfish from northern Brazil, with comments on phylogenetic relationships inside the subfamily Rhamdiinae (Siluriformes: Pimelodidae). Proceedings of the Biological Society of Washington, 107(4): 760-777.

Bockmann, F. A. 1998. Análise filogenética da família Heptapteridae (Teleostei, Ostariophysi, Siluriformes) e redefinição de seus gêneros. Unpublished Ph.D. Dissertation, Universidade de São Paulo, São Paulo, 599p.

Bockmann, F. A. \& C. J. Ferraris, Jr. 2005. Systematics of the Neotropical catfish genera Nemuroglanis Eigenmann and Eigenmann 1889, Imparales Schultz 1944, and Medemichthys Dahl 1961 (Siluriformes: Heptapteridae). Copeia, 2005(1): 124-137.

Bockmann, F. A. \& G. M. Guazzelli. 2003. Family Heptapteridae (Heptapterids). Pp. 406-431. In: Reis, R. E., S. O. Kullander \& C. J. Ferraris, Jr. (Eds.). Check List of the Freshwater Fishes of South and Central America. Porto Alegre, Edipucrs, 729p.

Bockmann, F. A. \& A. M. Miquelarena. 2008. Anatomy and phylogenetic relationships of a new catfish species from northeastern Argentina with comments on the phylogenetic relationships of the genus Rhamdella Eigenmann and Eigenmann 1888 (Siluriformes, Heptapteridae). Zootaxa, 1780: 1-54.

Bockmann, F. A. \& M. C. C. de Pinna. 2004. Heptapterus collettii Steindachner, 1881: a member of the Asian bagrid genus Olyra erroneously assigned to the Neotropical fauna (Siluriformes: Ostariophysi). Copeia, 2004(3): 665-675.

Bockmann, F. A. \& I. Sazima. 2004. Trichomycterus maracaya, a new catfish from the upper rio Paraná, southeastern Brazil (Siluriformes: Trichomycteridae), with notes on the T. brasiliensis species-complex. Neotropical Ichthyology, 2(2): 61-74.

Buckup, P. A. 1988. The genus Heptapterus (Teleostei, Pimelodidae) in southern Brazil and Uruguay, with the description of a new species. Copeia, 1988(3): 641-653.

Buckup, P. A. 1998. Characidium lagosantense Travassos, 1947. Pp. 483-485. In: Machado, A. B. M., G. A. B. Fonseca, R. B. Machado, L. M. D. Aguiar \& L. V. Martins (Eds.). Livro Vermelho das Espécies Ameaçadas de Extinção da Fauna de Minas Gerais. Belo Horizonte, Fundação Biodiversitas, 608p.

Casatti, L., F. R. Carvalho, J. L. Veronezi Jr. \& D. R. Lacerda. 2006. Reproductive biology of the neotropical superfetaceous Pamphorichthys hollandi (Cyprinodontiformes: Poeciliidae). Ichthyological Exploration of Freshwaters, 17(1): 59-64.

Casatti, L. \& R. M. C. Castro. 1998. A fish community of the São Francisco River headwaters riffles, southeastern Brazil. Ichthyological Exploration of Freshwaters, 9(3): 229-242.

Castellanos-Morales, C. A. 2008. Trichomycterus uisae: a new species of hypogean catfish (Siluriformes: Trichomycteridae) from the northern Andean Cordillera of Colombia. Neotropical Ichthyology, 6(3): 307-314.

Castro, R. M. C., L. Casatti, H. F. Santos, A. L. A. Melo, L. S. F. Martins, K. M. Ferreira, F. Z. Gibran, R. C. Benine, M. Carvalho, A. C. Ribeiro, T. X. Abreu, F. A. Bockmann, G. Z. Pelição, R. Stopiglia \& F. Langeani. 2004. Estrutura e composição da ictiofauna de riachos da bacia do Rio Grande no Estado de São Paulo, sudeste do Brasil. Biota Neotropica, 4(1): 1-39.
Castro, R. M. C. \& E. Trajano. 1993. Uma nova espécie de Pimelodidae cego de cavernas da Bahia, Brasil. P. 67. In: X Encontro Brasileiro de Ictiologia, 09 a 13/02/1993, São Paulo, Universidade de São Paulo, resumos. São Paulo, Universidade de São Paulo/Instituto Oceanográfico da USP, 430p.

Costa, W. J. E. M. 1987. Feeding habits of a fish community in a tropical coastal stream, rio Mato Grosso, Brazil. Studies in Neotropical Fauna and Environment, 22(3): 145-153.

Culver, D. C. \& H. Wilkens. 2000. Critical review of the relevant theories of the evolution of subterranean animals. Pp. 381-398. In: Wilkens, H., D. C. Culver \& W. F. Humphreys (Eds.). Ecosystems of the World, 30. Subterranean Ecosystems. Amsterdam, Elsevier, 382p.

DoNascimiento, C., F. Provenzano \& J. G. Lundberg. 2004. Rhamdia guasarensis (Siluriformes: Heptapteridae), a new species of cave catfish from the Sierra de Perijá, northwestern Venezuela. Proceedings of the Biological Society of Washington, 117(4): 564-574.

Fernandez, L., L. J. Saucedo, F. M. Carvajal-Vallejos \& S. A. Schaefer. 2007. A new phreatic catfish of the genus Phreatobius Goeldi 1905 from groundwaters of the Iténez River, Bolivia (Siluriformes: Heptapteridae). Zootaxa, 1626: 51-58.

Ferraris, C. J., Jr. 1988. Relationships of the neotropical catfish genus Nemuroglanis, with a description of a new species (Osteichthys: Siluriformes: Pimelodidae). Proceedings of the Biological Society of Washington, 101(3): 509-516.

Ferraris, Jr., C. J. \& F. Mago-Leccia. 1989. A new genus and species of pimelodid catfish from the Río Negro and Río Orinoco drainages of Venezuela (Siluriformes: Pimelodidae). Copeia, 1989(1): 166-171.

Figueiredo, C. A. A. 1997. Revisão taxonômica e filogenia de Pamphorichthys Regan 1913 (Cyprinodontiformes; Poeciliidae). Unpublished M.Sc. Dissertation, Universidade Federal do Rio de Janeiro, Rio de Janeiro. 108p.

Galvis, G., J. I. Mojica \& F. Rodríguez. 1989. Estudio Ecológico de una Laguna de Desborde del Río Metica. Bogotá, Universidad Nacional de Colombia, 164p.

Haseman, J. D. 1911. Some new species of fishes from the rio Iguassú. Annals of the Carnegie Museum, 7(3/4): 374-387, pl. 48 (fig. 2), 50 (fig. 2), 73-83.

Hattori, M., Y. Sawada, Y. Takag, R. Suzuki, T. Okada \& H. Kumai. 2003. Vertebral deformities in cultured red sea bream, Pagrus major, Temminck and Schlegel. Aquaculture Research, 34(13): 1129-1137.

Herrick, C. J. 1899. The cranial and first spinal nerves of Menidia. A contribution upon the nerve components of the bony fishes. Archives of Neurology and Psychopathology, 2: 1-299.

Herrick, C. J. 1901. The cranial nerves and cutaneous sense organs of the North American siluroid catfishes. The Journal of Comparative Neurology, 11(3): 177-249.

Hoeinghaus, D. J., K. O. Winemiller \& D. C. Taphorn. 2004. Compositional change in fish assemblages along the Andean piedmont - Llanos floodplain gradient of the río Portuguesa, Venezuela. Neotropical Ichthyology, 2(2): 85-92.

Karmann, I., R. Fraga \& L. F. Mendes. 2002. Poço Encantado, Chapada Diamantina (Itaetê), BA. Caverna com lago subterrâneo de rara beleza e importância científica. Pp. 491501. In: Schobbenhaus, C., D. A. Campos, M. Winge \& M. Berbert-Born (Eds.). Sítios Geológicos e Paleontológicos do Brasil. Brasília, Departamento Nacional de Produção Mineral, 554p. 
Langecker, T. G. 1992. Light sensitivity of cave vertebrates. Behavioral and morphological aspects. Pp. 295-326. In: Camacho, A. I. The natural history of biospeleology. Madrid, Museo Nacional de Ciencias Naturales/Consejo Superior de Investigaciones Científicas, Monografias del Museo Nacional de Ciencias Naturales, 680p.

Langecker, T. G. \& G. Longley. 1993. Morphological adaptations of the Texas blind catfishes Trogloglanis pattersoni and Satan eurystomus (Siluriformes: Ictaluridae) to their underground environment. Copeia, 1993(4): 976-986.

Lima, F. C. T., L. R. Malabarba, P. A. Buckup, J. F. Pezzi da Silva, R. P. Vari, A. Harold, R. Benine, O. T. Oyakawa, C. S. Pavanelli, N. A. Menezes, C. A. S. Lucena, M. C. S. L. Malabarba, Z. M. S. Lucena, R. E. Reis, F. Langeani, L. Cassati, V. A. Bertaco, C. Moreira \& P. H. F. Lucinda. 2003. Genera incertae sedis in Characidae. Pp. 106-169. In: Reis, R. E., S. O. Kullander \& C. J. Ferraris Jr. (Eds.). Check List of Freshwater Fishes of South and Central America. Porto Alegre, Edipucrs, 729p.

Lucena, C. A. S. 2000. Revisão taxonômica e filogenia das espécies transandinas do gênero Roeboides Günther (Teleostei: Ostariophysi: Characiformes). Comunicações do Museu de Ciências e Tecnologia da PUCRS, Série Zoologia, 13:3-63.

Lucena, C. A. S. 2007. Revisão taxonômica das espécies do gênero Roeboides grupo-affinis (Ostariophysi, Characiformes, Characidae). Iheringia, Série Zoologia, 97(2): 117-136.

Lucena, C. A. S. \& N. A. Menezes. 2003. Subfamily Characinae (Characins, tetras). Pp. 200-208. In: Reis, R. E., S. O. Kullander \& C. J. Ferraris Jr. (Eds.). Check List of Freshwater Fishes of South and Central America. Porto Alegre, Edipucrs, $729 \mathrm{p}$.

Lucinda, P. H. F. 2003. Family Poeciliidae (Livebearers). Pp. 555581. In: Reis, R. E., S. O. Kullander \& C. J. Ferraris Jr. (Eds.). Check List of Freshwater Fishes of South and Central America. Porto Alegre, Edipucrs, 729p.

Lundberg, J. G. 1982. The comparative anatomy of the toothless blindcat, Trogloglanis pattersoni Eigenmann, with a phylogenetic analysis of the ictalurid catfishes. Miscellaneous Publications, Museum of Zoology, University of Michigan, 163: $1-85$

Lundberg, J. G. 1992. The phylogeny of ictalurid catfishes: a synthesis of recent work. Pp. 392-420. In: Mayden, R. (Ed.). Systematics, Historical Ecology, and North American Freshwater Fishes. Stanford, Stanford University Press, 969p.

Lundberg, J. G. \& J. N. Baskin. 1969. The caudal skeleton of the catfishes, Order Siluriformes. American Museum Novitates, 2398: 1-49.

Lundberg, J. G., A. H. Bornbusch \& F. Mago-Leccia. 1991. Gladioglanis conquistador n. sp., from Ecuador with diagnoses of the subfamilies Rhamdiinae Bleeker and Pseudopimelodinae n. subf. (Siluriformes, Pimelodidae). Copeia, 1991(1): 190-209.

Lundberg, J. G. \& L. A. McDade. 1986. On the South American catfish Brachyrhamdia imitator Myers (Siluriformes, Pimelodidae), with phylogenetic evidence for a large intrafamilial lineage. Notulae Naturae, 463: 1-24.

Lütken, C. F. 1875. Velhas-Flodens Fiske. Et Bidrag til Brasiliens Ichthyologi. Videnskabelige Selskap Skrifter, 12(2): 123-252, xxi.

Malabarba, L. R. 1998. Monophyly of the Cheirodontinae, characters and major clades (Ostariophysi: Characidae). Pp. 193-233. In: Malabarba, L. R., R. E. Reis, R. P. Vari, Z. M. Lucena \& C. A. S. Lucena (Eds.). Phylogeny and Classification of Neotropical Fishes. Porto Alegre, Edipucrs, 603p.
Malabarba, L. R. \& Z. M. S. Lucena. 1995. Phenacogaster jancupa, new species, with comments on the relationships and a new diagnosis of the genus. Ichthyological Exploration of Freshwaters, 6(4): 337-344.

Marques, A. C. \& P. Gnaspini. 2001. The problems of characters susceptible to parallel evolution in phylogenetic reconstructions: suggestion of a practical method and its application to cave animals. Cladistics, 17(4): 371-381.

Mees, G. F. 1986. Records of Auchenipteridae and Pimelodidae from French Guiana (Pisces, Nematognathi). Proceedings of the Koninklijke Nederlandse Akademie van Wetenschappen, Series C, 89(3): 311-325.

Mendes, L. F. 1994. Ecology and behaviour of a new species of troglobitic catfish from northeastern Brazil (Siluriformes, Pimelodidae). P. 44. In: Messana, G. (Ed.). XI International Symposium of Biospeleology, Firenze, Castello di Montegufoni, 28 August - 2 September, 1994, Abstracts. Firenze, Société de Biospéologie/Università e CNR di Firenze, xiii, 65p.

Mendes, L. F. 1995a. Ecologia populacional e comportamento de uma nova espécie de bagres cavernícolas da Chapada Diamantina, BA (Siluriformes, Pimelodidae). Unpublished M. Sc. Dissertation, Universidade de São Paulo, São Paulo, 86p.

Mendes, L. F. 1995b. Ecologia e comportamento de um novo bagre troglóbio. Pp. L1-L2. In: XI Encontro Brasileiro de Ictiologia, 6 a 10 de fevereiro de 1995, resumos. Campinas, Pontifícia Universidade Católica de Campinas - ICB/Sociedade Brasileira de Ictiologia, unpag.

Mendes, L. F. 1995c. Observations on the ecology and behaviour of a new species of a troglobitic catfish from Northeastern Brazil. Mémoires de Biospéologie, 22: 99-101.

Mendes, L. F. 1995d. Poço Encantado. Impressão e Expressão, 21: 15-17.

Mendes, L. F. 1997a. A casa encantada. Terra, 4: 70-71.

Mendes, L. F. 1997b. Comportamento agressivo e reação à luz de uma nova espécie de bagres cegos da Chapada Diamantina, BA. P. 395. In: XII Encontro Brasileiro de Ictiologia, 24 a 28 de fevereiro de 1997, resumos. São Paulo, Instituto Oceanográfico da USP/Sociedade Brasileira de Ictiologia, 421p.

Mendes, L. F. 1998a. A caverna Poço Encantado e seus habitantes bagres cegos. P. 26. In: Rubbioli, E. L. Mergulho no sertão baiano. Projeto Hidro-Carste. O Carste, 10(1): 20-27.

Mendes, L. F. 1998b. Bioespeleologia do Hidro-Carste. P. 27. In: Rubbioli, E. L. Mergulho no sertão baiano. Projeto Hidro-Carste. O Carste, 10(1): 20-27.

Mendes, L. F., M. A. Vale \& P. H. Lara. 1997. História natural de uma nova espécie de bagres cegos da Chapada Diamantina, BA. P. 196. In: XII Encontro Brasileiro de Ictiologia, 24 a 28 de fevereiro de 1997, resumos. São Paulo, Instituto Oceanográfico da USP/ Sociedade Brasileira de Ictiologia, 421p.

Menezes, N. A., S. H. Weitzman, O. T. Oyakawa, F. C. T. Lima, R. M. C. Castro \& M. J. Weitzman. 2007. Peixes de Água Doce da Mata Atlântica. Lista Preliminar das Espécies e Comentários sobre Conservação de Peixes de Água Doce Neotropicais. Freshwater fishes of Mata Atlântica. Preliminary List of Species and Comments on Conservation of Neotropical Freshwater Fishes. São Paulo, Museu de Zoologia - Universidade de São Paulo, 408p.

Miquelarena, A. M. \& R. C. Menni. 1999. Rhamdella aymarae, a new species from the Itiyuro River, northern Argentina (Siluriformes: Pimelodidae). Ichthyological Exploration of Freshwaters, 10(3): 201-210. 
Mohr, C. E. \& T. L. Poulson. 1966. The Life of the Cave. New York, McGraw-Hill Book Co., 232p.

Muriel-Cunha, J. \& M. C. C. de Pinna. 2005. New data on cistern catfish, Phreatobius cisternarum, from subterranean waters at mouth of the Amazon River (Siluriformes, Incertae sedis). Papéis Avulsos de Zoologia, 45(26): 327-339.

Northcutt, G. 1989. The phylogenetic distribution and innervation of craniate mechanoreceptive lateral line: neurobiology and evolution. Pp. 17-78. In: Coombs, S. P., P. Görner \& H. Münz (Eds.). The Mechanosensory Lateral Line. New York, Springer Verlag, 724p.

Pavan, C. 1946. Observations and experiments on the cave fish Pimelodella kronei and its relatives. American Naturalist, 80: 343-380.

Pavanelli, C. S. 2003. Family Parodontidae (Parodontids). Pp. 4650. In: Reis, R. E., S. O. Kullander \& C. J. Ferraris Jr. (Eds.). Check List of Freshwater Fishes of South and Central America. Porto Alegre, Edipucrs, 729p.

Poly, W. J. \& C. E. Boucher. 1996. Nontroglobitic fishes in caves: their abnormalities, ecological classification and importance. American Midland Naturalist, 136(1): 187-198.

Poulson, T. L. 1971. Biology of cave and deep sea organisms: a comparison. Bulletin of the National Speleological Society, 33(1): 51-61.

Poulson, T. L. 2001. Adaptations of cave fishes with some comparisons to deep-sea fishes. Environmental Biology of Fishes, 62(1/3): 345-364.

Rasquin, P. \& L. Rosenbloom. 1954. Endocrine imbalance and tissue hyperplasia in teleosts maintained in darkness. Bulletin of the American Museum of Natural History, 104(4): 363425.

Reichel, M. 1927. Étude anatomique du Phreatobius cisternarum Goeldi, silure aveugle du Brésil. Revue Suisse de Zoologie, 34(16): 285-403.

Ribeiro, A. C. 2006. Tectonic history and the biogeography of the freshwater fishes from the coastal drainages of eastern Brazil: an example of faunal evolution associated with a divergent continental margin. Neotropical Ichthyology, 4(2): 225-246.

Ribeiro, A. C., F. C. T. Lima, C. Riccomini \& N. A. Menezes. 2006. Fishes of the Atlantic Rainforest of Boracéia: testimonies of the Quaternary fault reactivation within a Neoproterozoic tectonic province in Southeastern Brazil. Ichthyological Exploration of Freshwaters, 17(2): 157-164.

Rubbioli, E. L. 1998. Mergulho no sertão baiano. Projeto HidroCarste. O Carste, 10(1): 20-27.

Santos, A. C. A. 2005. Peixes. Pp. 311-335. In: Juncá, F., L. Funch \& W. Rocha (Eds.). Biodiversidade e Conservação da Chapada Diamantina. Brasília, Ministério do Meio Ambiente, 411p.

Santos, A. C. A. \& É. P. Caramaschi. 2007. Composition and seasonal variation of the ichthyofauna from Upper Rio Paraguaçu (Chapada Diamantina, Bahia, Brazil). Brazilian Archives of Biology and Technology, 50(4): 663-672.

Sazima, I. \& F. A. Machado. 1982. Hábitos e comportamento de Roeboides prognathus, um peixe lepidófago. Boletim de Zoologia, 7: 37-56.

Sazima, I. \& J. P. Pombal Jr. 1986. Um albino de Rhamdella minuta, com notas sobre comportamento (Osteichthyes, Pimelodidae). Revista Brasileira de Biologia, 46(2): 377-381.

Shelden, F. F. 1937. Osteology, myology and probable evolution of the nematognath pelvic girdle. Annals of the New York Academy of Sciences, 37(1): 1-96.
Shibatta, O. A., J. Muriel-Cunha \& M. C. C. de Pinna. 2007. A new subterranean species of Phreatobius Goeldi, 1905 (Siluriformes, Incertae sedis) from the Southwestern Amazon basin. Papéis Avulsos de Zoologia, 47(17): 191-201.

Silfvergrip, A. M. C. 1996. A Systematic Revision of the Neotropical Catfish Genus Rhamdia (Teleostei, Pimelodidae). Stockholm, Stockholm University, 156p.

Souza, I. L., O. Moreira Filho \& R. M. C. Castro. 1994. Informações citogenéticas preliminares de uma nova espécie de Pimelodidae cego de cavernas (Itaetê, BA). P. 18. In: V Simpósio de Citogenética Evolutiva Aplicada de Peixes Neotropicais, programa e resumos. Botucatu, Unesp, 91p.

Swarça, A. C., L. G. Caetano \& A. L. Dias. 2000. Cytogenetic of species of the families Pimelodidae and Rhamdiidae (Siluriformes). Genetics and Molecular Biology, 23(3): 589-593.

Taylor, W. R. \& G. C. van Dyke. 1985. Revised procedures for staining and clearing small fishes and other vertebrates for bone and cartilage study. Cybium, 9(2): 107-119.

Trajano, E. 1993. Considerations about systematics and the evolution of behaviour in siluriform cave fishes. Mémoires de Biospéologie, 20: 257-260.

Trajano, E. 1995. Evolution of tropical troglobites: applicability of the model of Quaternary climatic fluctuations. Mémoires de Biospéologie, 22: 203-209.

Trajano, E. 1996. Os peixes que (sobre)vivem em cavernas. Ciência Hoje, 21(122): 16-19.

Trajano, E. 1997a. Food and reproduction of Trichomycterus itacarambiensis, cave catfish from southeastern Brazil (Siluriformes: Trichomycteridae). Journal of Fish Biology, 51: 53-63.

Trajano, E. 1997b. Synopsis of Brazilian troglomorphic fishes. Mémoires de Biospéologie, 24: 119-126.

Trajano, E. 1997c. Population ecology of Trichomycterus itacarambiensis, a cave catfish from eastern Brazil (Siluriformes, Trichomycteridae). Environmental Biology of Fishes, 50(4): 357-369.

Trajano, E. 1997d. Ecologia populacional de Trichomycterus sp., bagre cavernícola de Minas Gerais (Trichomycteridae). P. 176. In: XII Encontro Brasileiro de Ictiologia, 24 a 28 de fevereiro de 1997, resumos. São Paulo, Instituto Oceanográfico da USP/ Sociedade Brasileira de Ictiologia, 421p.

Trajano, E. 1997e. Sinopse dos peixes troglomorficos no Brasil. P. 386. In: XII Encontro Brasileiro de Ictiologia, 24 a 28 de fevereiro de 1997, resumos. São Paulo, Instituto Oceanográfico da USP/ Sociedade Brasileira de Ictiologia, 421p.

Trajano, E. 1998. As cavernas de Campo Formoso, Bahia. Biologia da Toca do Gonçalo, com ênfase em uma nova espécie de bagres troglóbios. O Carste, 10(3): 84-91.

Trajano, E. 2001a. Ecology of subterranean fishes: an overview. Environmental Biology of Fishes, 62(1/3): 133-160.

Trajano, E. 2001b. Habitat and population data of troglobitic armored cave catfish, Ancistrus cryptophthalmus Reis, 1987, from central Brazil (Siluriformes: Loricariidae). Environmental Biology of Fishes, 62(1/3): 195-200.

Trajano, E. 2003. Ecology and ethology of subterranean catfishes. Pp. 601-635. In: Arratia, G., B. G. Kapoor, M. Chardon \& R. Diogo (Eds.). Catfishes. Enfield, Science Publishers, Inc., $812 \mathrm{p}$.

Trajano, E. 2007. The challenge of estimating the age of subterranean lineages: examples from Brazil. Acta Carsologica, 36(1): 191-198.

Trajano, E. \& M. E. Bichuette. 2005a. Os encantos das cavernas. Pp. 100-103. In: Teixeira, W. \& R. Linsker (Eds.). Chapada Diamantina: Águas no Sertão. São Paulo, Terra Virgem, 160p. 
Trajano, E. \& M. E. Bichuette. 2005b. Diversity of subterranean fishes in Brazil. Pp. 161-163. In: Gilbert, J. (Ed.). World Subterranean Biodiversity. Proceedings of an international symposium held on 8-10 December 2004 in Villeurbanne, France. Villeurbanne, Université Claude Bernard Lyon 1/CNRS, 182p.

Trajano, E. \& M. E. Bichuette. 2006. Biologia Subterrânea: Introdução. São Paulo, Redespeleo, 92p.

Trajano, E. \& M. E. Bichuette. 2007. Population ecology of cave armoured catfish, Ancistrus cryptophthalmus Reis 1987, from central Brazil (Siluriformes: Loricariidae). Ecology of Freshwater Fish, 16(2): 105-115.

Trajano, E. \& F. A. Bockmann. 1997. Relictual distribution in subterranean organisms: cave fishes from northeastern Brazil. Pp. 72-73. In: International Symposium on Phylogeny and Classification and Neotropical Ichthyological Association, 9th Annual Meeting, 20-26 July, Porto Alegre - RS - Brasil, program and abstracts. Porto Alegre, Museu de Ciências e Tecnologia - PUCRS, 96p.

Trajano, E. \& F. A. Bockmann. 1998. Evolution of behaviour in cave-dwelling heptapterine catfishes (Teleostei: Siluriformes). P. 86. In: 17 th Meeting of the Willi Hennig Society, program and abstracts. Hennig XVII, a time for integration, São Paulo, September 21-25 1998. São Paulo, Universidade de São Paulo, 95p.

Trajano, E. \& F. A. Bockmann. 1999a. Evolution of ecology and behaviour in Brazilian heptapterine cave catfishes, based on cladistic analysis (Teleostei: Siluriformes). Mémoires de Biospéologie, 26: 123-129.

Trajano, E. \& F. A. Bockmann. 1999b. Evolution of behaviour and ecology of Brazilian cave catfishes. P. 70. In: Holcer, D. \& M. Šašic (Eds.). Abstracts of the 14th International Symposium of Biospeleology. Makarska, Croatia, 19th - 26th September 1999. Makarska, Croatian Biospeleological Society, 125p.

Trajano, E. \& F. A. Bockmann. 2000. Ecology and behaviour of a new cave catfish of the genus Taunayia from northeastern Brazil (Siluriformes, Heptapterinae). Ichthyological Exploration of Freshwaters, 11(3): 207-216.

Trajano, E., L. Duarte \& L. Menna-Barreto. 2005. Locomotor activity rhythms in cave fishes from Chapada Diamantina, northeastern Brazil (Teleostei: Siluriformes). Biological Rhythm Research, 36(3): 229-336.

Trajano, E. \& P. Gerhard. 1997. Light reaction in Brazilian cave fishes (Siluriformes: Pimelodidae, Trichomycteridae, Loricariidae). Mémoires de Biospéologie, 24: 127-138.

Trajano, E. \& L. Menna-Barreto. 1995. Locomotor activity pattern of Brazilian cave catfishes under constant darkness (Siluriformes, Pimelodidae). Biological Rhythm Research, 26(3): 341-353.

Trajano, E. \& L. Menna-Barreto. 1996. Free-running locomotor activity rhythms in cave-dwelling catfishes, Trichomycterus sp., from Brazil (Teleostei, Siluriformes). Biological Rhythm Research, 27(3): 329-335.

Trajano, E. \& L. Menna-Barreto. 2000. Locomotor activity rhythms in cave catfishes, genus Taunayia, from eastern Brazil (Teleostei: Siluriformes: Heptapterinae). Biological Rhythm Research, 31(4): 469-480.

Trajano, E., N. Mugue, J. Krejca, C. Vidthayanon, D. Smart \& R. Borowsky. 2002. Habitat, distribution, ecology and behavior of cave balitorids from Thailand (Teleostei: Cypriniformes). Ichthyological Exploration of Freshwaters, 13(2): 169-184.

Trajano, E. \& M. C. C. de Pinna. 1996. A new cave species of Trichomycterus from eastern Brazil (Siluriformes, Trichomycteridae). Revue française d'Aquariologie, 23(3/4): 85-90.
Trajano, E., R. E. Reis \& M. E. Bichuette. 2004. Pimelodella spelaea: a new cave catfish from Central Brazil, with data on ecology and evolutionary considerations (Siluriformes: Heptapteridae). Copeia, 2004(2): 315-325.

Trajano, E. \& L. E. Sánchez. 1994. Brésil. Pp. 527-540. In: Juberthie, C. \& V. Decu (Eds.). Encyclopaedia Biospeologica. Tome I. Moulis, Société de Biospéologie, 834p.

Travassos, H. 1947. Contribuição ao estudo da família Characidae Gill, 1893. V - Redescrição do genótipo de Characidium Reinhardt, 1866, com uma análise da literatura e descrição de Characidium lagosantensis n. sp. Summa Brasiliensis Biologiae, 1(14): 251-309.

Volpato, G. L. \& E. Trajano. 2006. Biological rhythms. Pp. 101153. In: Val, A. L., V. M. Almeida-Val \& D. J. Randall (Eds.). Fish Physiology, Vol. 21. The Physiology of Tropical Fishes. Amsterdam, Elsevier Science \& Technology, 400p.

Weber, A., G. Allegrucci \& V. Sbordoni. 2003. Rhamdia laluchensis, a new species of troglobitic catfish (Siluriformes: Pimelodidae) from Chiapas, Mexico. Ichthyological Exploration of Freshwaters, 14(3): 273-280.

Weber, A. \& H. Wilkens. 1998. Rhamdia macuspanensis: a new species of troglobitic pimelodid catfish (Siluriformes: Pimelodidae) from a cave in Tabasco, Mexico. Copeia, 1998(4): 998-1004.

Weitzman, S. H. \& R. P. Vari. 1988. Miniaturization in South American freshwater fishes; an overview and discussion. Proceedings of the Biological Society of Washington, 101(2): 444-465.

Wilkens, H. 1986. The tempo of regressive evolution: studies of the eye reduction in stygobiont fishes and decapod crustaceans of the Gulf Coast and West Atlantic region. Stygologia, 2(1/2): 131-143.

Wilkens, H. 1988. Evolution and genetics of epigean and cave Astyanax fasciatus (Characidae, Pisces). Evolutionary Biology, 23: 271-367.

Wilkens, H. 1993. A new species of Rhamdia (Pisces: Pimelodidae) from a cave in the Sierra de Zongolica (Veracruz, Mexico). Mitteilungen aus dem Hamburgischen Zoologischen Museum und Institut, 90: 375-378.

Wilkens, H. 2001. Convergent adaptations to cave life in the Rhamdia laticauda catfish group (Pimelodidae, Teleostei). Environmental Biology of Fishes, 62(1/3): 251-261.

Winemiller, K. O. 1989. Ontogenetic diet shifts and resource partitioning among piscivorous fishes in the Venezuelan llanos. Environmental Biology of Fishes, 26(3): 177-199.

Winterbottom, R. 1974. A descriptive synonymy of the striated muscles of the Teleostei. Proceedings of the Academy of Natural Sciences of Philadelphia, 125: 225-317.

Zuanon, J. A. S., F. A. Bockmann \& I. Sazima. 2006. A remarkable sand-dwelling fish assemblage from central Amazonia, with comments on the evolution of psammophily in South American freshwater fishes. Neotropical Ichthyology, 4(1): $107-118$

Accepted June 20, 2010

Published December 16, 2010 